Review

\title{
Advances and Recent Trends in Heterogeneous Photo(Electro)-Catalysis for Solar Fuels and Chemicals
}

\author{
James Highfield \\ Heterogeneous Catalysis, Institute of Chemical \& Engineering Sciences (ICES, A * Star), \\ 1 Pesek Road, Jurong Island, 627833, Singapore; E-Mail: james_highfield@ices.a-star.edu.sg; \\ Tel.: +65-6796-3805; Fax: +65-6316-6188
}

Academic Editor: Pierre Pichat

Received: 20 January 2015 / Accepted: 20 March 2015 / Published: 15 April 2015

\begin{abstract}
In the context of a future renewable energy system based on hydrogen storage as energy-dense liquid alcohols co-synthesized from recycled $\mathrm{CO}_{2}$, this article reviews advances in photocatalysis and photoelectrocatalysis that exploit solar (photonic) primary energy in relevant endergonic processes, viz., $\mathrm{H}_{2}$ generation by water splitting, bio-oxygenate photoreforming, and artificial photosynthesis $\left(\mathrm{CO}_{2}\right.$ reduction). Attainment of the efficiency ( $>10 \%$ ) mandated for viable techno-economics (USD 2.00-4.00 per $\mathrm{kg} \mathrm{H}_{2}$ ) and implementation on a global scale hinges on the development of photo(electro)catalysts and co-catalysts composed of earth-abundant elements offering visible-light-driven charge separation and surface redox chemistry in high quantum yield, while retaining the chemical and photo-stability typical of titanium dioxide, a ubiquitous oxide semiconductor and performance "benchmark". The dye-sensitized $\mathrm{TiO}_{2}$ solar cell and multi-junction Si are key "voltage-biasing" components in hybrid photovoltaic/photoelectrochemical (PV/PEC) devices that currently lead the field in performance. Prospects and limitations of visible-absorbing particulates, e.g., nanotextured crystalline $\alpha-\mathrm{Fe}_{2} \mathrm{O}_{3}, \mathrm{~g}-\mathrm{C}_{3} \mathrm{~N}_{4}$, and $\mathrm{TiO}_{2}$ sensitized by $\mathrm{C} / \mathrm{N}$-based dopants, multilayer composites, and plasmonic metals, are also considered. An interesting trend in water splitting is towards hydrogen peroxide as a solar fuel and value-added green reagent. Fundamental and technical hurdles impeding the advance towards pre-commercial solar fuels demonstration units are considered.
\end{abstract}

Keywords: solar fuels; heterogeneous photocatalysis; water splitting; renewable hydrogen; visible sensitization; hydrogen peroxide; bio-oxygenates photoreforming; electrocatalysis; carbon dioxide reduction 


\section{Introduction}

In 2004 Nobel Laureate Richard Smalley, discoverer of fullerenes and pioneer of modern nanoscience, gave a talk on the 10 great challenges facing humanity in the 3rd millenium. Placing energy at the top of the list, he proposed divestiture of fossil fuels in favour of sustainable and environmentally benign alternatives [1]. He also envisioned that nanotechnology, i.e., the design and assembly of nanometer scale structures, would play a key role in our future prosperity. In fact, it can be argued that nanomaterials have already been exploited for many years in the form of heterogeneous catalysts in industrial chemical processing, responsible for the rapid growth in civilized life during the 20th century. Much of this was done with only marginal understanding of their workings prior to the advent of in-situ surface characterization, high-resolution imaging tools, and theoretical (computational) modeling [2,3]. Nowadays, the development of nanocatalysts with functionality optimized "by rational design" is a popular theme [4-8] but it remains an uphill challenge due to the myriad complexity of catalytic phenomena [9]. Nonetheless, recent articles focusing on the prospects for such materials in renewable energy applications give some ground for optimism [10-12]. They also introduce the main topic of this report, viz., the prodigious growth in research into heterogeneous photocatalysis, as attested by the drastic increase in literature citations over the last 20 years. While many of these concern environmental or "advanced oxidation" applications [13], multitudinous examples related to energy topics can be located under key (search) phrases like solar fuels, photo-catalytic hydrogen, photo-reforming, water photo-splitting, $\mathrm{CO}_{2}$ photo-reduction, etc. A photocatalyst can be defined as "a solid material that accelerates a chemical reaction by light absorption while itself remaining unchanged" [14]. Just as in a thermal heterogeneous catalyst, a chemical process is made faster due to a significant lowering of the energy barrier of the associated transition state, e.g., by providing surface sites that activate unique modes of adsorption. On a typical semiconductor photocatalyst like titanium dioxide $\left(\mathrm{TiO}_{2}\right)$, the adsorbed (dark) state is further activated (or entirely new states are created) by surface interaction with highly energetic photo-induced charges, viz., electrons $\left(\mathrm{e}^{-}\right)$and holes $\left(\mathrm{h}^{+}\right)$. Band-gap excitation of $\mathrm{TiO}_{2}(\lambda \leq 400 \mathrm{~nm})$ creates photons with an energy $\geq 300 \mathrm{~kJ} / \mathrm{mol}$. In principle, the use of photocatalysts enables substitution of expensive process heat by cheap solar (photon) energy, leading to reduced operating costs. However, an added impetus for research is that they can also drive endergonic (thermodynamically uphill) processes by converting light energy into stored chemical energy (bond enthalpy). In other words, the reaction selectivity can be steered towards more useful products. By analogy with the natural process, when the reactants are water and carbon dioxide, this is sometimes referred to as artificial photosynthesis [15], in which $\mathrm{H}_{2}$ and/or its reaction product with $\mathrm{CO}_{2}$ is isolated as a solar fuel.

To better appreciate the future impact of any viable solar fuel technology, it is helpful to consider it in the broader context of renewable energy schemes and their current limitations. In principle, the ideal energy carrier from an energetic and environmental viewpoint is hydrogen. On a weight basis, it has the highest energy density of any fuel ( $143 \mathrm{MJ} / \mathrm{kg}$, or $3 \times$ the value of gasoline) and it burns cleanly and efficiently to water, producing heat and/or electrical power in a fuel cell [16]. Unfortunately, $\mathrm{H}_{2}$ also has the lowest volumetric energy density under ambient conditions $(0.011 \mathrm{MJ} / \mathrm{L})$, making its storage in physical form (compressed, liquefied, adsorbed, etc.) impractical and expensive, especially for applications in the transportation sector [17]. Any renewable fuel should retain the positive attributes of gasoline but offer the environmental benefits of $\mathrm{H}_{2}$. It must be a liquid (for ease of handling) and have a practical energy 
density ( $\geq 20 \mathrm{MJ} / \mathrm{L})$. It should also contain a substantial level of "incipient hydrogen" ( $\geq 12 \mathrm{wt} \%)$ and be carbon-neutral in the long term. The recent (transitional) strategy of fuel "decarbonization" aims to exploit the clean energy associated with the H-component in fossil fuels as these become depleted [18].

A previous review by this author [19] dealt almost exclusively with thermal heterogeneous catalytic processes in a future renewable hydrogen energy system schematized in Figure 1.

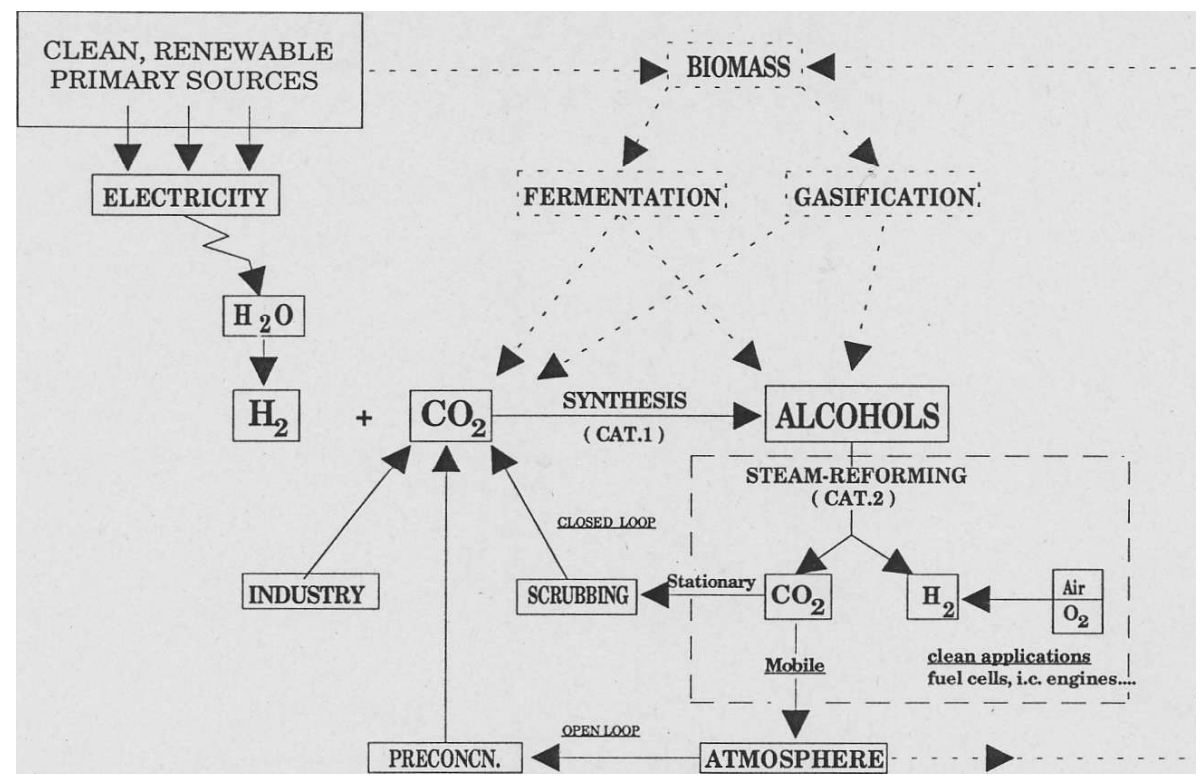

Figure 1. Idealized energy scheme based on renewable $\mathrm{H}_{2}$ stored in simple alcohols (reproduced from [19] with permission).

In a gas phase catalytic process, $\mathrm{H}_{2}$ derived from renewable primary sources (solar-electric, hydro-electric, etc.) is converted to alcohol(s) by a synthesis reaction with $\mathrm{CO}_{2}$, itself recycled from industrial sources in concentrated form (closed loop). In the near future, the more challenging (open loop) process, i.e., direct capture of $\mathrm{CO}_{2}$ from the atmosphere, may become technical reality [20,21]. Simple alcohols are ideal $\mathrm{H}$-carriers as they can be synthesized quite selectively while $\mathrm{H}_{2}$ can be released at relatively low temperature. Insofar as biomass can supply renewable $\mathrm{H}_{2}$, alcohols and oxygenates (even sugars) by gasification, fermentation, carbohydrate hydrolysis, etc. [22], this natural renewable $\left(\mathrm{CO}_{2}\right.$-neutral) energy source is integrated into the overall scheme. Essentially the same scientific precepts have since been advanced in a monograph by Olah et al., which focuses on storage solely as methanol since this is already technically feasible [23]. The current status of The Methanol Economy has been the subject of a recent review, which re-emphasizes that the price of the alcohol will be strongly dependent on the cost of renewable electricity for $\mathrm{H}_{2}$ generation [24]. Cost analyses show that "renewable" methanol will probably be 2-3× more expensive than the methane-based commodity [25] (see also Section 7). As regards the main catalytic cycle, the alcohol(s) synthesis can be written in general form as:

$$
\mathrm{n} \mathrm{CO}_{2}+3 \mathrm{n} \mathrm{H}_{2} \leftrightarrow \mathrm{C}_{\mathrm{n}} \mathrm{H}_{2 n+1} \mathrm{OH}+(2 \mathrm{n}-1) \mathrm{H}_{2} \mathrm{O}
$$

Under high pressure, reaction $(1)$ is favoured $(\Delta \mathrm{G}<0)$ at ambient temperature but synthesis catalysts generally operate above $220{ }^{\circ} \mathrm{C}$ due to kinetic limitations. Product selectivity in ethanol synthesis is a 
major challenge [26,27]. Upon demand, $\mathrm{H}_{2}$ is released catalytically from aqueous alcohol vapours to generate heat and power via steam-reforming (SR):

$$
\mathrm{C}_{\mathrm{n}} \mathrm{H}_{2 \mathrm{n}+1} \mathrm{OH}+(2 \mathrm{n}-1) \mathrm{H}_{2} \mathrm{O} \leftrightarrow \mathrm{n} \mathrm{CO} 2+3 \mathrm{n} \mathrm{H}_{2}
$$

SR is an endothermic process $(\Delta \mathrm{H} \geq 0)$ but reaction (2) is theoretically feasible $(\Delta \mathrm{G} \leq 0)$ near ambient for methanol, and above $230^{\circ} \mathrm{C}$ for ethanol due to the molar volume increase (entropy factor). Since SR is simply the reverse of synthesis, catalysts for both reactions are similar. Formulations based on $\mathrm{Cu}$ (modified by $\mathrm{Co}, \mathrm{Ni}, \mathrm{Pd}, \mathrm{Rh}$, etc.) on various oxide supports are quite effective. The main technical hurdle is the need for "fuel processing" because low levels of carbon monoxide in the reformate poison the fuel cell $(\mathrm{Pt})$ anode and must be eliminated [28,29]. In addition, although it has been a growing area of research in the last 20 years, ethanol SR still suffers from catalyst deactivation due to carbon deposition, probably linked to the high temperatures necessary to establish good conversion rates [30,31]. Nevertheless, the scope for bio-hydrogen resources now encompasses a range of oxygenates and polyols, e.g., glycerol (a waste product from bio-diesel synthesis [32,33]), in which coking can be minimized via aqueous-phase-reforming (APR) under mild conditions [34].

For maximum technical impact, photocatalysis should logically be applied to the most energy-demanding steps in the scheme under consideration. Artificial photosynthesis to create a fuel such as methanol from aqueous $\mathrm{CO}_{2}$ :

$$
\mathrm{CO}_{2}+2 \mathrm{H}_{2} \mathrm{O} \leftrightarrow \mathrm{CH}_{3} \mathrm{OH}+1.5 \mathrm{O}_{2}
$$

is highly endothermic $(\Delta \mathrm{H}=+727 \mathrm{~kJ} / \mathrm{mol})$ but can be driven by solar photons in the visible/near IR region because it is $6 \mathrm{e}^{-}$process. Since reaction (3) involves water splitting ( $\mathrm{H}$ abstraction) implicitly, it effectively couples two stages in the above scheme $\left(\mathrm{H}_{2}\right.$ generation and methanol synthesis), offering a potential process simplification. Supplying the energy needed for (endothermic) steam-reforming of alcohols $\left(\Delta \mathrm{H}^{\circ} \approx+130 \mathrm{~kJ} / \mathrm{mol} \mathrm{CH}_{3} \mathrm{OH}\right.$ or $\left.+175 \mathrm{~kJ} / \mathrm{mol} \mathrm{C}_{2} \mathrm{H}_{5} \mathrm{OH}\right)$ by means of photons is another obvious prospect, giving rise to intensive recent interest in photo-reforming [35]. In the review that follows, space limitations and a plethora of recent review articles [10,11,36-56] act as major con-straints on detail and impose a necessarily high degree of selectivity in given examples. Similarly, the emerging field of "renewable fuels from $\mathrm{CO}_{2}$ and $\mathrm{H}_{2} \mathrm{O}$ by solar-thermal processes" is beyond its scope [57]. As the title implies, this review deals only with materials that respond to (absorb) a significant fraction of the solar power spectrum, over $90 \%$ of which lies in the visible and near infrared region. Thus, recent advances in "sensitization" methods for $\mathrm{TiO}_{2}$, the benchmark photocatalyst, are covered in some depth along with exploration of stable and non-toxic semiconductors of more suitable bandgap, either for independent use or in tandem (composite) arrangement for improved efficiency. The author has endeavoured to strike a balance between topicality and novelty, and apologizes in advance to the many authors who are not cited directly. Advances in selected materials are given regardless of their testing configuration, be it as dispersed nanoparticles in suspension or as "wired" electrodes in a photoelectrochemical cell (PEC). The question of the degree of complexity of any solar fuel "device", its future amenability to scale-up, and ultimate impact on process techno-economics (fuel cost) is still at an early stage of evaluation [58-62]. This is considered near the end of the review, along with the inevitable trend towards devices composed of "earth-abundant" elements [62-68], as necessitated by the ultimate (global) scale of fossil fuels replacement (see Section 7). 


\section{Water Splitting and Target Efficiency in Solar Hydrogen Generation}

The fundamental groundwork in evaluating the maximum efficiency achievable in a solar photonic device was done by Bolton and co-workers [69-71], taking water splitting as the model reaction:

$$
\mathrm{H}_{2} \mathrm{O} \rightarrow \mathrm{H}_{2}+0.5 \mathrm{O}_{2}
$$

This two-electron, or effectively two-photon (one photon per $\mathrm{H}$ atom), reduction process is highly energetic and thermodynamically uphill by $237 \mathrm{~kJ} / \mathrm{mol} \mathrm{H}_{2}$ or $119 \mathrm{~kJ} / \mathrm{mol}$ photons, corresponding to a wavelength of $1008 \mathrm{~nm}(1.23 \mathrm{eV}$-all redox potentials are given $v s$. the normal hydrogen electrode at $\mathrm{pH}=0)$. Inspection of the solar spectrum in Figure 2 shows that photons of greater energy $(\lambda \leq 1008 \mathrm{~nm})$ constitute only one half of the total incident solar flux.

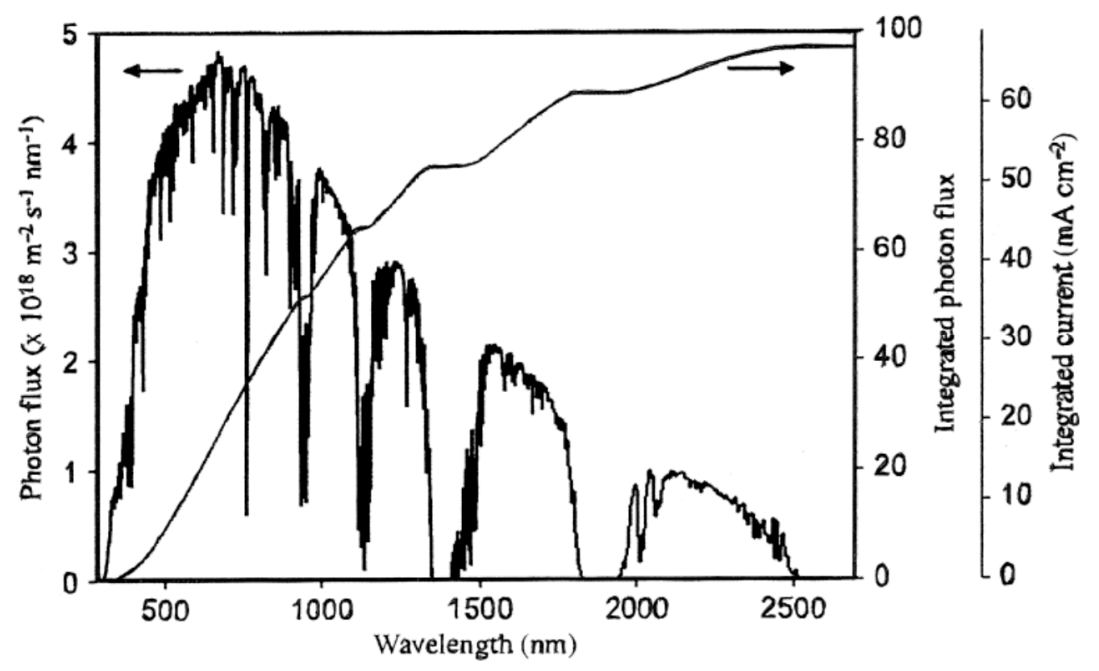

Figure 2. Solar photon flux at the earth's surface $v s$. wavelength and integrated current density obtainable from an ideal PV cell (adapted from [72] with permission of Elsevier).

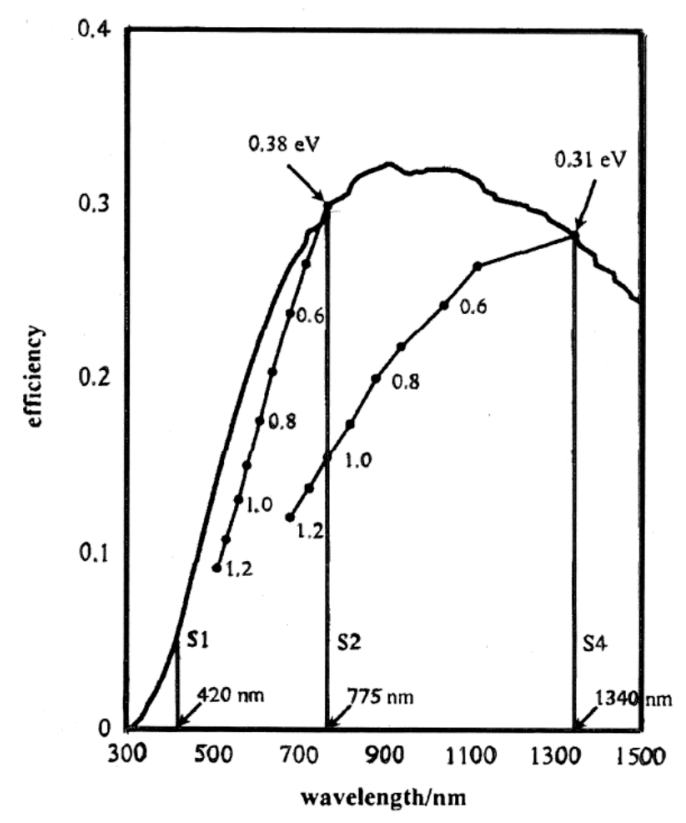

Figure 3. Solar photon-to-chemical energy conversion efficiency in a single bandgap current device (adapted from [71] with permission of Elsevier). 
Furthermore, not all the energy in these photons is available for chemical energy storage after absorption due to intraband thermalization, i.e., ultra-fast relaxation from excited vibrational states of the first electronic excited state (or conduction band in a semiconductor). To compensate for this energy loss the wave-length threshold must shift to $775 \mathrm{~nm}$ in this so-called S2 process, as shown in Figure 3. When entropic losses (non-equivalence of internal energy and Gibbs energy) are also factored in, the maximum efficiency $\left(\eta_{\mathrm{STH}}\right)$ of a device for solar-to-hydrogen (STH) energy conversion based on a single photo-system is around 30\%. Also shown in Figure 3 are plots with more realistic entropic losses $(>0.4 \mathrm{eV})$ and their progressive erosion of efficiency. In principle, a $4 \mathrm{e}^{-}(\mathrm{S} 4)$ process extends the useful spectral range to $1340 \mathrm{~nm}$ based on successive absorption of two low energy photons to drive a single electron event like proton discharge $\left(\mathrm{H}^{+}+\mathrm{e}^{-} \rightarrow \mathrm{H} \cdot\right)$. For a semiconductor, this is a futuristic concept because it would require hypothetical long-lived mid-gap states to be populated in the first photon absorption event, as shown in Figure 4. This will require a major advance in "bandgap engineering", but may yield so-called 3rd generation photocatalysts (vide infra) [73,74].

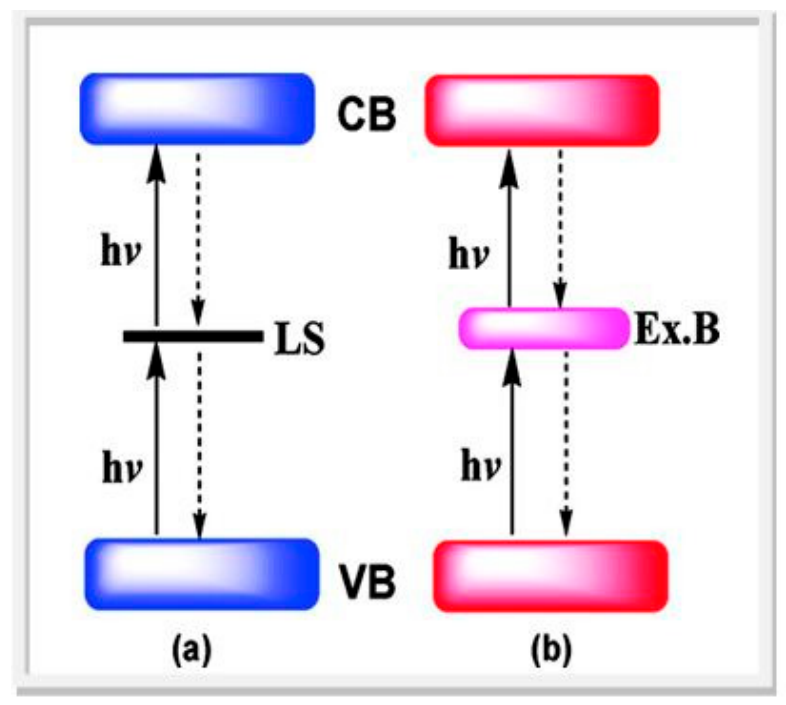

Figure 4. Successive two-photon excitation (a) via localized dopant states (LS) (b) via delocalized states in an extrinsic band (Ex.B) (reproduced from [74] with permission of ACS.

On the other hand, coupling of two absorbers of complementary bandgap and band-edge position (type II -see Figure 5) each absorbing two photons in a dual (D4) or tandem device is a viable water splitting configuration and offers better matching to the solar spectrum $[75,76]$. In practice, the mechanistic complexity (kinetic barrier) in the water oxidation half-cell reaction has kept conversion efficiencies below $2 \%$ until recently [60-62,77,78]. Efficiencies in the more challenging process of $\mathrm{CO}_{2}$ photo-reduction are still below $0.5 \%$ [79]. The minimum workable efficiency for implementation of any solar-to-hydrogen ( $\mathrm{STH}$ ) process is taken as $10 \%$, leading to a $\mathrm{H}_{2}$ price approaching the DOE target of $\$ 4.00$ per $\mathrm{kg}$ [60]. Immediately obvious from Figures 2 and 3 is that pristine $\mathrm{TiO}_{2}$, the prototypical semiconductor photocatalyst [80,81] with a band-gap of $\sim 3 \mathrm{eV}(\lambda \leq 400 \mathrm{~nm})$, absorbs just $4 \%$ of solar light. However, since this oxide is cheap and non-toxic and has otherwise excellent material properties, suitable energetics (band edge positions) to drive both proton reduction and water oxidation, stability in aqueous environment, etc., ways of sensitizing $\mathrm{TiO}_{2}$ to visible light are being studied intensively. At the same time, other non- $\mathrm{TiO}_{2}$-based systems with intrinsic visible absorption are urgently sought. 


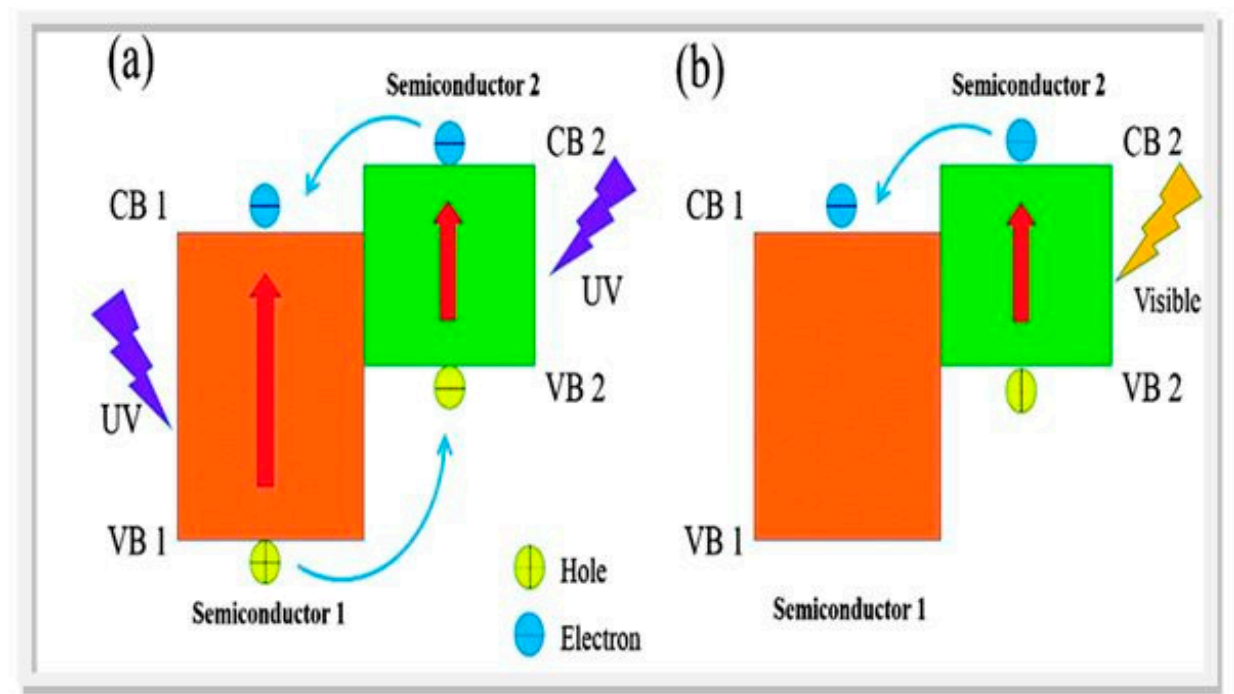

Figure 5. Dual absorbers with complementary bandgap/band edge positions (type II heterojunction) under (a) UV; and (b) Visible excitation (reproduced from [82] with permission of PCCP Owner Societies).

Incorporation of materials that perform efficient solar light harvesting is a fundamental (thought not the only) pre-condition for an effective energy conversion device. While it is generally assumed that absorption of one photon of energy exceeding the bandgap creates one electron/hole pair (exciton) with $100 \%$ efficiency, the fate of these excited states is less clear. One advantage of screening photocatalysts in "wired" mode, e.g., as photoanodes in an electrochemical cell, is that it promotes better charge separation via "band-bending", viz., the space-charge (depletion) layer formed spontaneously at the semiconductor/liquid junction. It also facilitates measurement of the combined efficiency of the two key initiatory processes (light absorption and charge collection) in terms of the resulting photocurrent. The incident photon-to-current conversion efficiency (IPCE) is a figure of merit for any photovoltaic (PV) cell. The photocurrent density limit shown in Figure $2\left(\sim 65 \mathrm{~mA} \cdot \mathrm{cm}^{-2}\right)$ is the ideal value achievable under so-called AM1.5G (1 Sun) illumination, corresponding to an incident optical power close to $1000 \mathrm{~W} \cdot \mathrm{m}^{-2}$ or $100 \mathrm{~mW} \cdot \mathrm{cm}^{-2}[72,83]$. In solar fuel generation, these photo-generated charges are required instead to drive surface redox chemistry, in which the presence of suitable co-catalysts and rapid turnover of the substrate (diffusion) are crucial to performance. Due to these kinetic limitations, STH efficiencies lie below the PV (IPCE) value.

\section{Advances in Absorber Materials with Improved Solar Spectral Matching}

\subsection{Modified $\mathrm{TiO}_{2}$}

The greatest success has been achieved in the so-called mesoscopic Dye-Sensitized Solar Cell (DSSC), or Grätzel cell as named after its inventor [84]. The basic principle is illustrated in Figure 6. Upon photo-excitation of the chemically-anchored dye monolayer, electrons are injected to the conduction band of the mesoporous $\mathrm{TiO}_{2}$ substrate indirectly via an excited state ( $\mathrm{S}^{*}$ ). Back electron transfer to the oxidized dye is prevented by rapid dye regeneration (reduction) by a donor species $\left(\mathrm{I}^{-}\right)$ present at high concentration in the electrolyte. To complete the circuit, the oxidized form of the mediator 
$\left(\mathrm{I}_{3}{ }^{-}\right)$is discharged by electron flow through the external circuit to the Pt cathode. The energy difference between the $\mathrm{TiO}_{2}$ conduction band and the redox level of the mediator $\left(\mathrm{I}^{-} / \mathrm{I}_{3}{ }^{-}\right)$determines the maximum open circuit voltage $\left(\mathrm{V}_{\mathrm{oc}} \approx 0.8 \mathrm{~V}\right.$ ), while the IPCE generally exceeds $70 \%$ up to $700 \mathrm{~nm}$, leading to photocurrent densities $\approx 15 \mathrm{~mA} \cdot \mathrm{cm}^{-2}$. With a typical "fill factor" (non-ideality in the power curve) of around 0.75 , the resulting overall efficiency is $\sim 10 \%$.

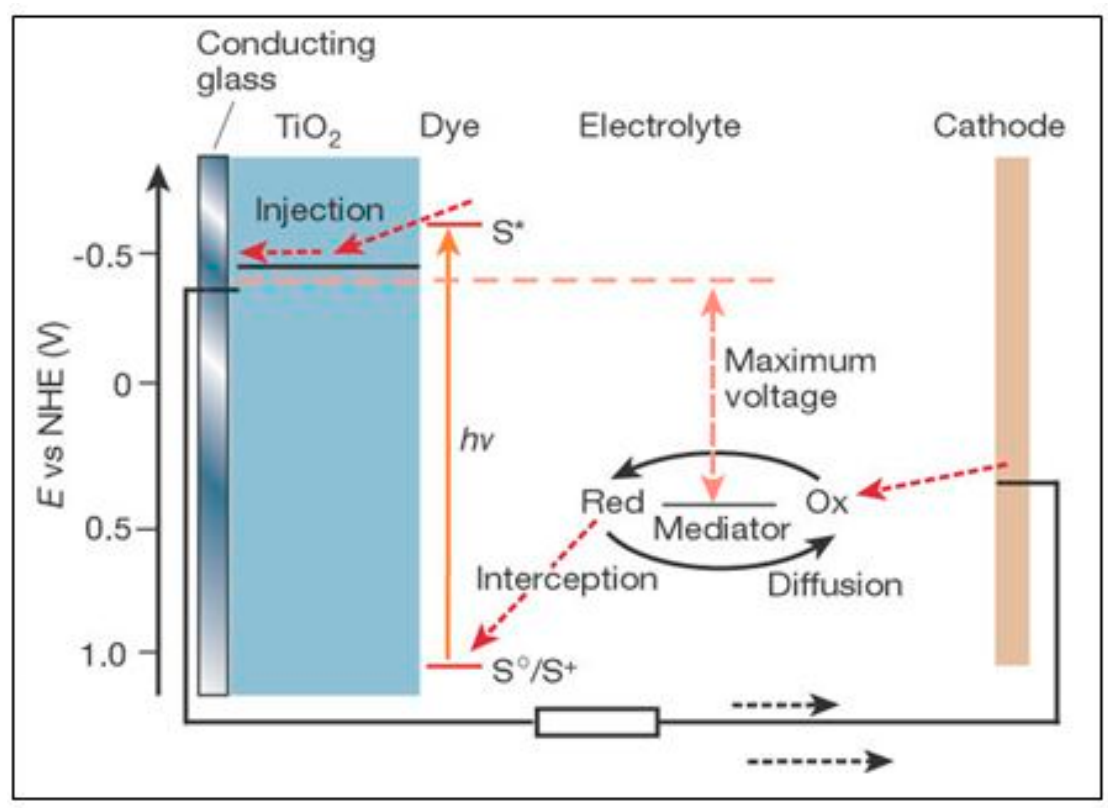

Figure 6. Working principle of dye-sensitized solar cell (DSSC) (reproduced from [76] with permission of Nature Publishing Group).

Most recently, this has been extended to $13 \%$ while at the same time reducing costs, substituting the previous Ru-based panchromatic (black) dyes with more absorptive (Zn-based) donor- $\pi$-acceptor porphyrins and the slightly corrosive $\mathrm{I}^{-} / \mathrm{I}_{3}^{-}$redox mediator by $\mathrm{Co}^{2+} / \mathrm{Co}^{3+}$-based electrolytes [85]. Although the DSSC is strictly speaking a photovoltaic (PV) device rivaling conventional $\mathrm{Si}$, their recent coupling into water splitting PEC cells has led to remarkably high efficiencies of $\mathrm{H}_{2}$ generation (vide infra) [61,62]. Future advances can be expected from co-sensitization utilizing mixed dye systems, one of which absorbs in the near infrared region [86-91]. Alternatively, by varying its surface binding configuration, a single dye may achieve charge injection by both direct (type II-as exemplified by catechol, EDTA, etc. (see Figure $7 \mathrm{~b}$ [92]) and indirect (type I-see Figure 7a) modes, thereby rendering it more panchromatic in response $[93,94]$. Although it has not yet come to fruition, pure type II sensitization should increase DSSC efficiency by eliminating the electron injection overpotential, i.e., the energy loss due to thermalization from the excited state of the dye $\left(\mathrm{S}^{*}\right)$ in the conventional (type I) process [93]. The general prospects for exploiting direct ligand-to-metal $\left(\mathrm{Ti}^{4+}\right)$ charge transfer (LMCT) absorption in photocatalysis over $\mathrm{TiO}_{2}$ have been reviewed [95]. It can be recognized by the appearance of a new absorption band absent in either of the free components. One serendipitous example is self-activation of hydrogen peroxide (which forms the yellow peroxotitanate complex on adsorption) for visible-driven environmental applications of $\mathrm{TiO}_{2}[95,96]$. The most exciting recent discovery in the DSSC field is the advantage of utilizing panchromatic semiconductor alkyl-ammonium lead (tin) trihalide perovskites as solid-state (layer) sensitizers [97-100], simultaneously replacing both the conventional dye and redox 
mediator. This technology-disruptive advance should ease fabrication costs and accelerate the development of a cheaper alternative solid-state PV cell of similar durability and efficiency to Si.

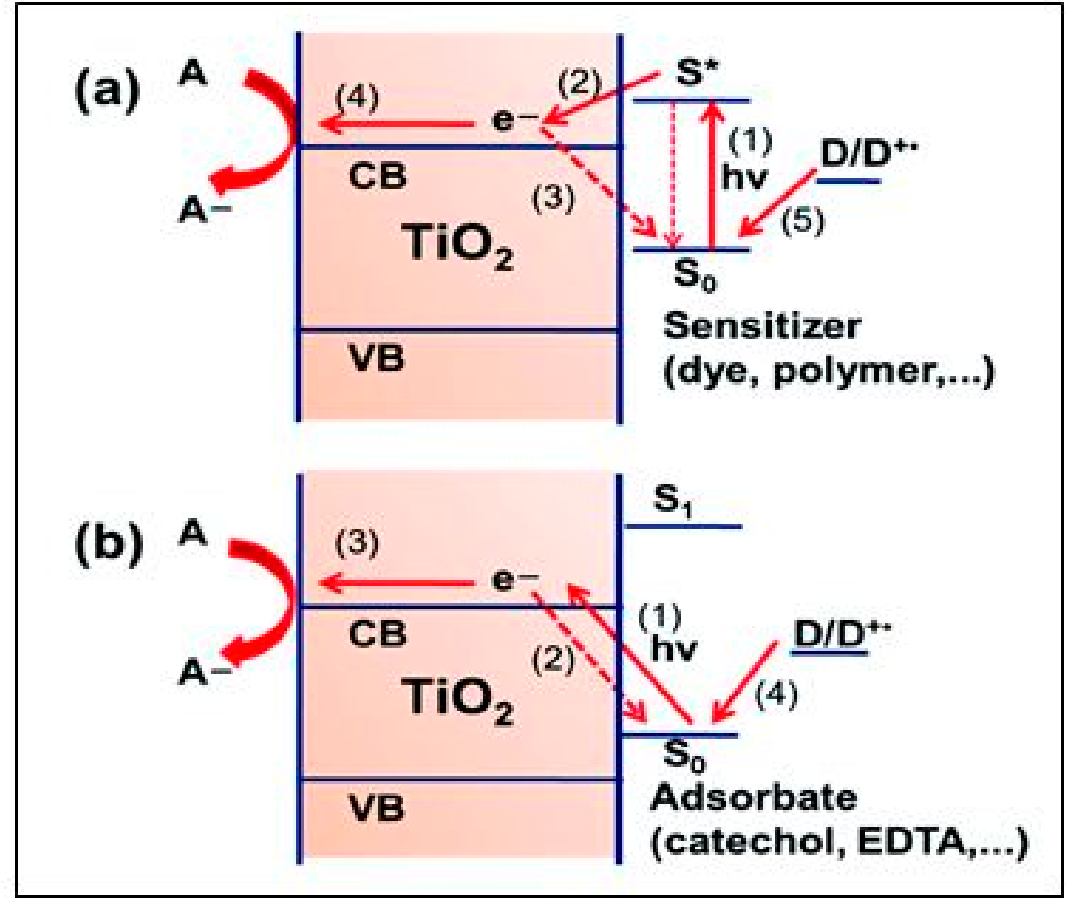

Figure 7. Scheme of charge transfer modes from sensitizer $(\mathrm{S})$ to the $\mathrm{TiO}_{2}$ conduction band (CB): (a) indirect (type I); (b) direct (type II or LMCT) (reproduced from [95] with permission of the Royal Society of Chemistry).

In particulate systems, bulk doping of $\mathrm{TiO}_{2}$ with inorganic (metallic or non-metallic) elements has been a major strategy for visible sensitization in the last decade. Although this approach offers better long-term photostability (as compared to sensitization by organic dyes), the complexities of the solid-state chemistry have been decidedly more challenging. This is linked primarily to restricted solubility of dopants when introduced individually (1-2 at \%), leading to insufficient visible light absorption. Furthermore, the concomitant introduction of defects that act as recombination centres has often led to efficiency losses. These are commonly O-vacancies but the dopant site itself can act deleteriously if present above a certain threshold concentration [101]. It is inadequate merely to impart colour to $\mathrm{TiO}_{2}$, e.g., from transition metal ions (TMI) with a $\mathrm{d}^{1}-\mathrm{d}^{9}$ electronic configuration. Such optical transitions, being mostly localized $(\mathrm{d} \leftrightarrow \mathrm{d})$ type, do not involve charge transfer and merely act as parasitic absorbers competing with genuine (delocalized) charge injection. In a few cases, intervalence charge transfer may be effective provided the energy state of the photo-reduced acceptor lies above the bottom of the conduction band, e.g., $\mathrm{Ti}^{3+}, \mathrm{V}^{2+}$, or $\mathrm{Fe}^{2+}$ [102]. Early interest in $\mathrm{TMI}$ doping in $\mathrm{TiO}_{2}$ was intended to improve the efficiency of charge separation and/or to extend the lifetime of surface-trapped carriers for photochemical action $[103,104]$. Any advantage to be gained by applying the TMI strategy to visible-light sensitization remains debatable as attested by more recent literature $[105,106]$. Indeed, it is increasingly recognized that incorporation of TMIs with empty $\left(\mathrm{d}^{0}\right)$ or filled $\left(\mathrm{d}^{10}\right) \mathrm{d}$-shells gets better results $[107,108]$. The recent flurry of excitement over the discovery of "black" $\mathrm{TiO}_{2}$, obtained by high-pressure hydrogenation [109], is fading since it was confirmed that little or no visible photoactivity 
is generated [110], even though UV activity can be dramatically increased. Nevertheless, it has led to theoretical modeling [111] and renewed interest in defect engineering in pure $\mathrm{TiO}_{2}$ [82,101,112].

The advent of what are now considered " 2 nd generation" photocatalysts $[82,113]$ was triggered by independent reports in 2001 and 2002 that doping with electron acceptors, i.e., elements forming anionic species such as N [114] and C [115], was the most effective way to impart visible-light sensitization. This was soon corroborated [116-119], and studies were extended to include F [120], S [121], and P [122]. Awareness of the benefits (synergies) of anionic co-doping gradually followed [123-125]. Thanks to good underpinning by DFT (calculational) modeling [117,126,127], most studies have focused on modified $\mathrm{N}-\mathrm{TiO}_{2}$ [128-130]. However, the visible sensitization effect is limited. $\mathrm{N}-\mathrm{TiO}_{2}$ generally appears pale yellow due to the low level of dopant achievable $(<2$ at $\% \mathrm{~N})$, conferring only weak absorption in the blue-green region (see Figure 8).

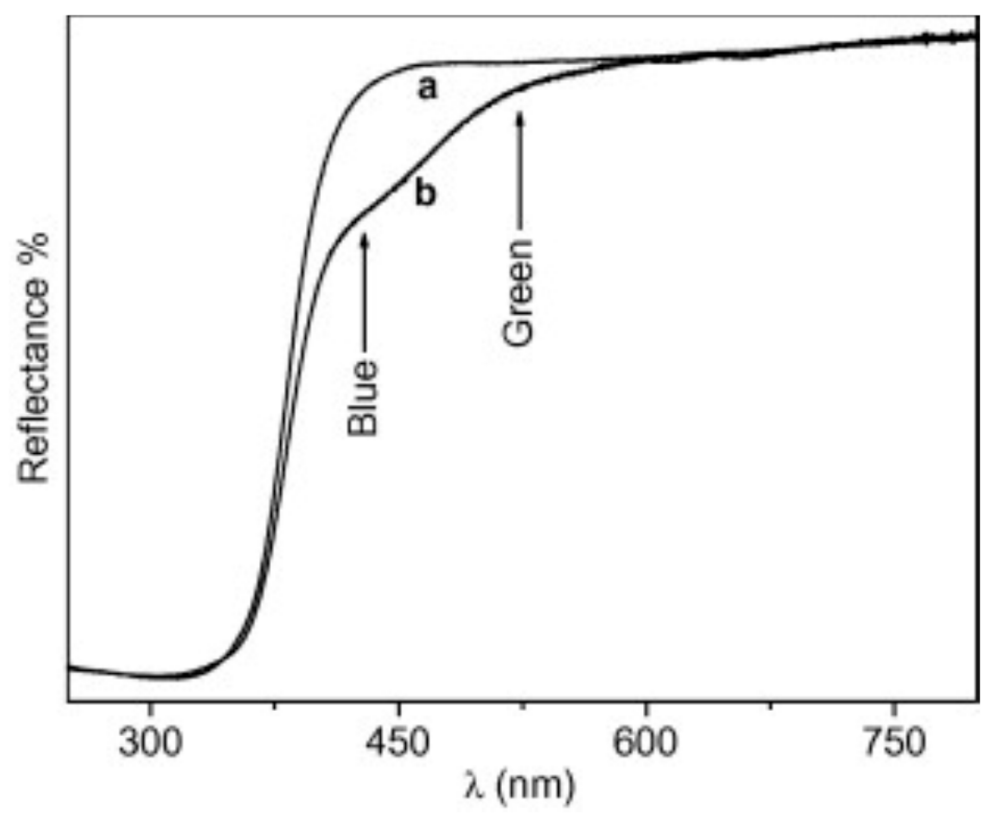

Figure 8. UV-visible reflectance spectra of (a) pristine $\mathrm{TiO}_{2}$ (b) N-doped $\mathrm{TiO}_{2}$ (reproduced from [126] with permission of Elsevier).

Furthermore, a number of studies have found a loss in oxidative power upon illumination within this visible band, and have attributed this mainly to faster charge carrier recombination [131-133]. Di Valentin et al. [126] have shown that the most stable doping configuration depends on the chemical potential of ambient oxygen during preparation. Since the most common reagent, $\mathrm{NH}_{3}$, has reducing properties O-poor conditions prevail, favouring combination of two substitutional nitrogen sites compensated by one O-vacancy $\left(2 \mathrm{~N}_{\mathrm{s}}+\mathrm{V}_{\mathrm{o}}\right)$. The implied diamagnetic material of formula $\mathrm{TiO}_{(2-3 \mathrm{x})} \mathrm{N}_{2 \mathrm{x}}$ has been affirmed as most likely by more recent modeling [127]. In an O-rich environment, a species consisting of an interstitial nitrogen atom associated with $\mathrm{O}\left(\mathrm{N}_{\mathrm{i}-\mathrm{O}}\right)$ may also be stable, interacting with lattice Ti atoms through its $\pi$-bonding states, as shown in Figure 9. In either case, new $\left(\mathrm{N}_{2 \mathrm{p}}\right)$ energy states predicted to lie slightly above the valence band could be responsible for the observed visible absorption band around $450 \mathrm{~nm}$. EPR spectroscopy has shown that irradiation within this band transfers an electron from the bulk diamagnetic $\mathrm{N}$ centre to the $\mathrm{TiO}_{2}$ surface leading to formation of superoxide species $\left(\mathrm{O}_{2} \cdot^{-}\right)$, a key activation process in environmental photocatalysis. 


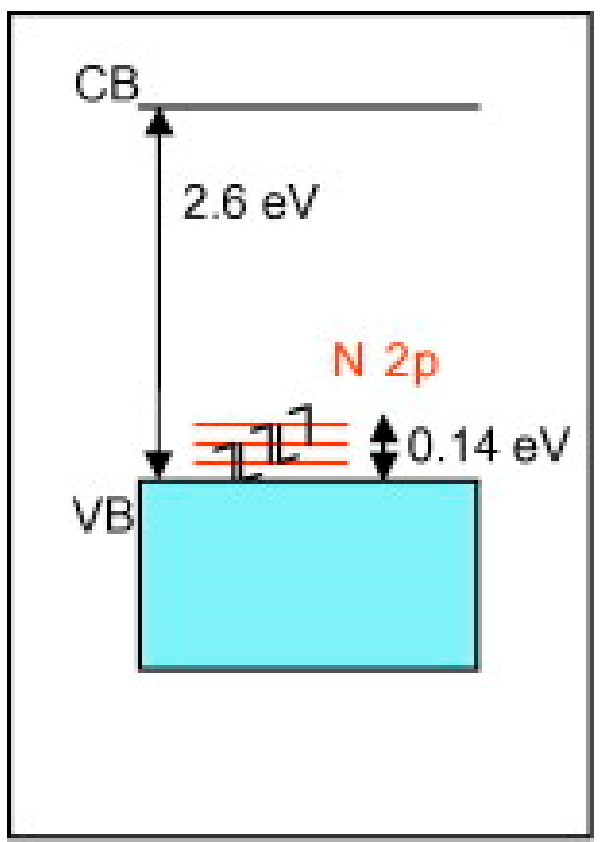

SUBSTITUTIONAL

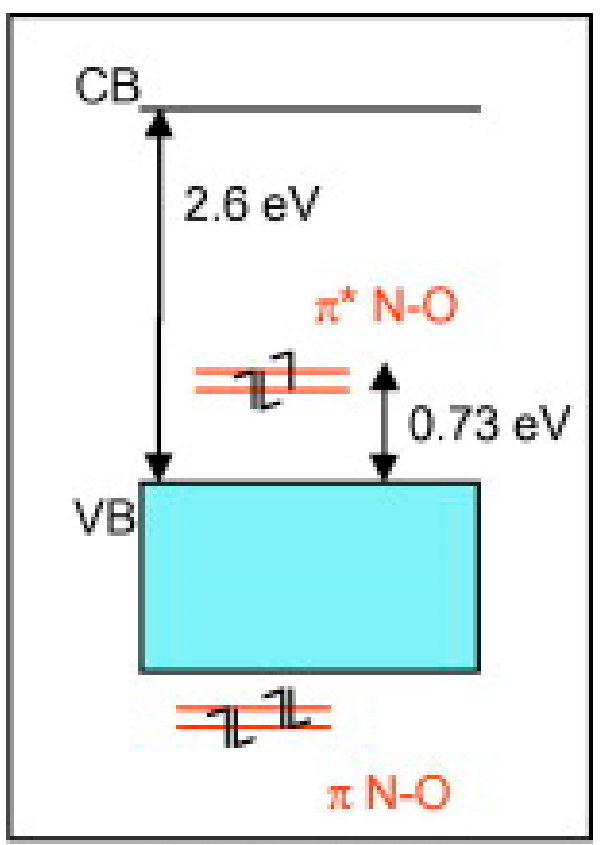

INTERSTITIAL

Figure 9. New energy states introduced into $\mathrm{TiO}_{2}$ by substitutional and interstitial nitrogen. (reproduced from [126] with permission of Elsevier).

The current theoretical viewpoint on bulk doping is to take a donor/acceptor cooperative approach. This can be electro-neutral, e.g., "B + N" [134] or "Mo + 2N" [135], combinations that form intra-gap states extending from the bottom of the conduction band and top of the valence band, respectively. Charge compensation reduces the risk of introducing detrimental structural defects (interstitials, vacancies, etc.), while enabling the incorporation of higher dopant levels. Alternatively, even non-compensated p,n-type co-doping has been proposed. Using an excess of donor, e.g., $\mathrm{Cr}>\mathrm{N}$, the creation of states of intermediate energy results in a quasi-continuum visible absorption and an apparent bandgap energy of $1.5 \mathrm{eV}$ [136]. The extrinsic states responsible for enhanced visible photoresponse often involve paramagnetic centres that can be explored by EPR [136,137].

One caveat on bulk doping should be mentioned. While re-affirming that $\mathrm{N}-\mathrm{TiO}_{2}$ has visible activity in formic acid mineralization, the same study claimed IR spectroscopic evidence for defective $\mathrm{Ti} \equiv \mathrm{N}$ bonds and correlated this with weaker UV photoactivity due to related loss of crystallinity [138]. It is not clear if this trade-off in performance is inevitable [130]. Finally, it should be recognized that the "band narrowing" strategy vis-à-vis solar fuel generation may ultimately be constrained by high overpotentials associated with key redox processes, e.g., water oxidation (vide infra). The corollary is that co-catalysts will have a more vital role to play in lowering kinetic barriers in visible-active semiconductors, materials of intrinsically lower redox power than pristine $\mathrm{TiO}_{2}$ (see Section 3.3).

A new class of more intensely coloured "multilayer-sensitized" titanias related to N-doped $\mathrm{TiO}_{2}$ has emerged recently. These are obtained via mild preparative routes like sol-gel, hydrothermal, etc., where the $\mathrm{N}$-source is usually organic instead of ammonia, the preferred reagent for bulk doping. Starting from urea, the organic moiety transforms stepwise during calcination into the yellow-brown melon structure based on tri-s-triazine (heptazine) rings [139-141], a process catalyzed by acidic (H)-titanates [142]. Insofar as melon is structurally related to the more-condensed (fully dehydrogenated) graphitic carbon 
nitride, g- $\mathrm{C}_{3} \mathrm{~N}_{4}$, a visible-absorbing semiconductor per se [143], these $\mathrm{N}$-modified materials resemble nanocomposites. Figure 10 shows examples of these structural tectons (building blocks) and their inter-relationship. Starting from amines or alkyl-ammonium salts, the material appears more intensely coloured (brown) already below $200{ }^{\circ} \mathrm{C}$ due to a strong absorption tail extending across most of the visible region [96,144-147]. However, unlike the case of melon, the exact identity of the chromophore is uncertain and it is thermally labile. Calcination weakens both visible absorption and photoactivity $[96,148]$. Representative UV-Vis spectra of various C,N-based sensitizers loaded onto biphasic anatase/titanates $(\mathrm{A} / \mathrm{T})$ are shown in Figure 11.
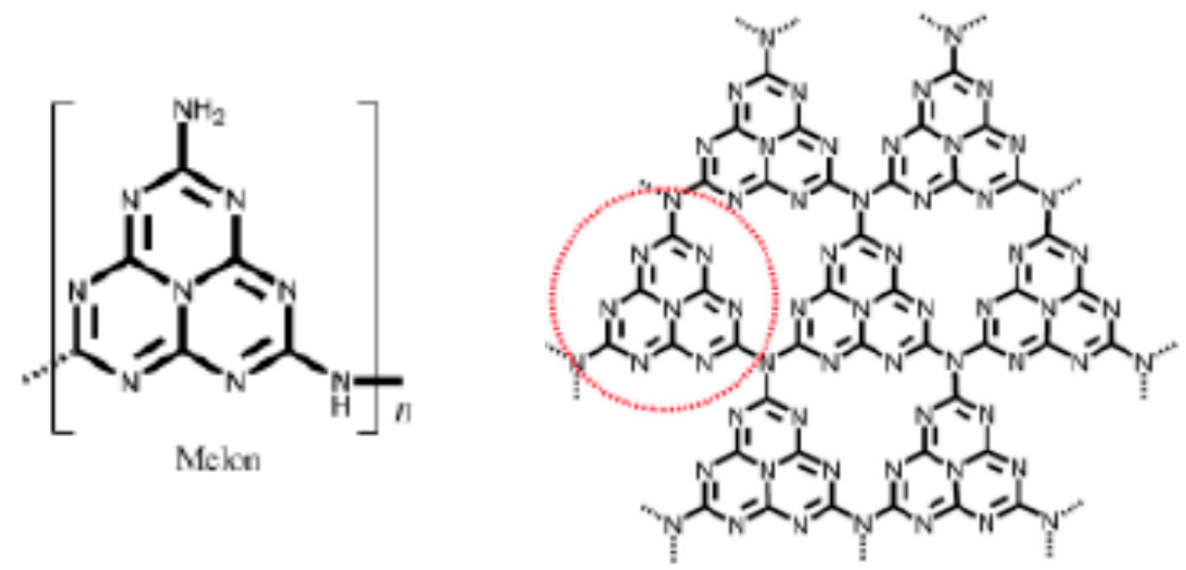

Figure 10. Melon and related tri-s-triazine unit (ringed) as building block for $g-\mathrm{C}_{3} \mathrm{~N}_{4}$ (adapted from [143] with permission of Wiley).

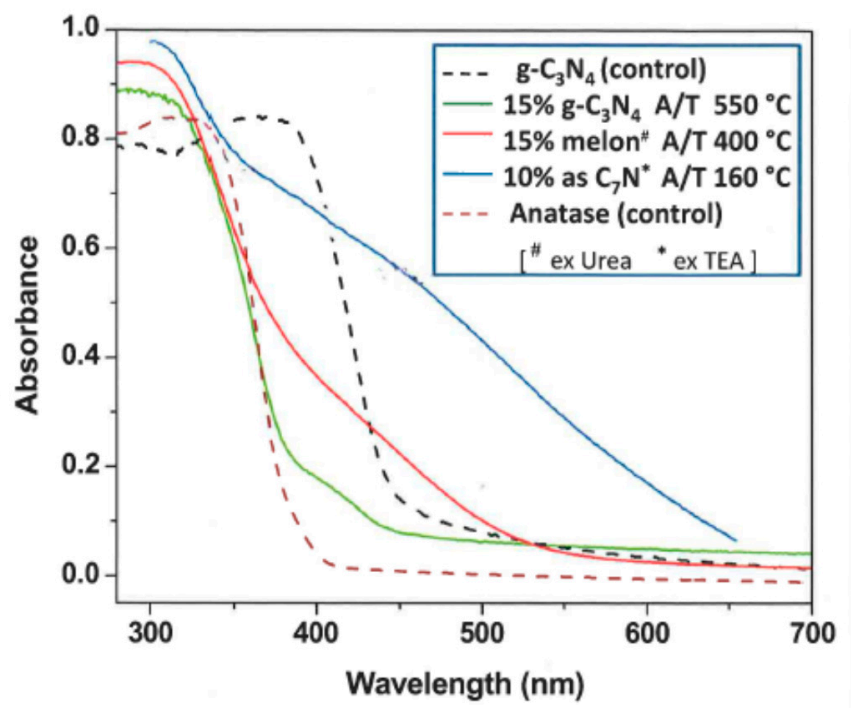

Figure 11. UV-Vis spectra of $\mathrm{C} / \mathrm{N}-$ based sensitizers on biphasic anatase/titanates (adapted from $[96,142]$ with permission).

Visible sensitization of $\mathrm{TiO}_{2}$ via "plasmonics" is another rapidly intensifying field that may yield 3rd generation photoactive materials [73,74]. Localized Surface Plasmon Resonance (LSPR) is responsible for the now familiar intense coloration of mono-dispersed colloidal noble metals like Au and Ag, in which the absorption band may be "tuned" by varying the particle size and shape. The first convincing 
report that visible-light-induced metal-to-semiconductor electron transfer can be induced in $\mathrm{Au} / \mathrm{TiO}_{2}$ appeared in 2005 [149]. The action spectrum (IPCE) for photo-oxidation of ethanol was found to match the Au optical absorption peaking at $\sim 550 \mathrm{~nm}$ (see Figure 12).

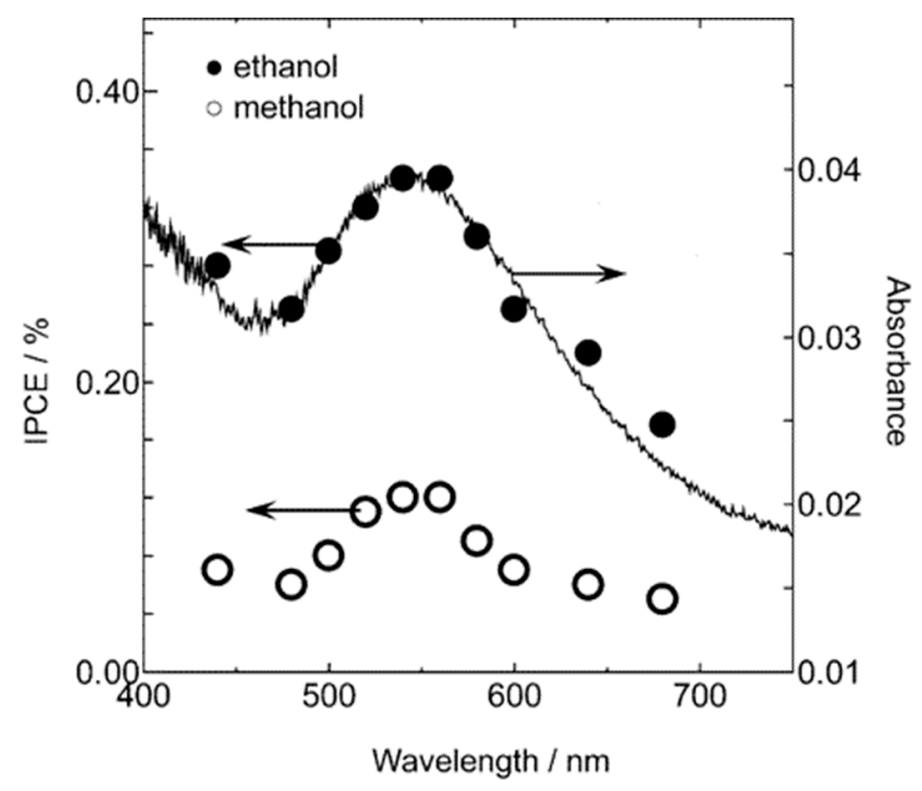

Figure 12. IPCE action spectrum in ethanol (methanol) photo-oxidation vs. LSPR (visible absorption) spectrum of gold in $\mathrm{Au} / \mathrm{TiO}_{2}$ (adapted from [149]; copyright (2005) American Chemical Society).

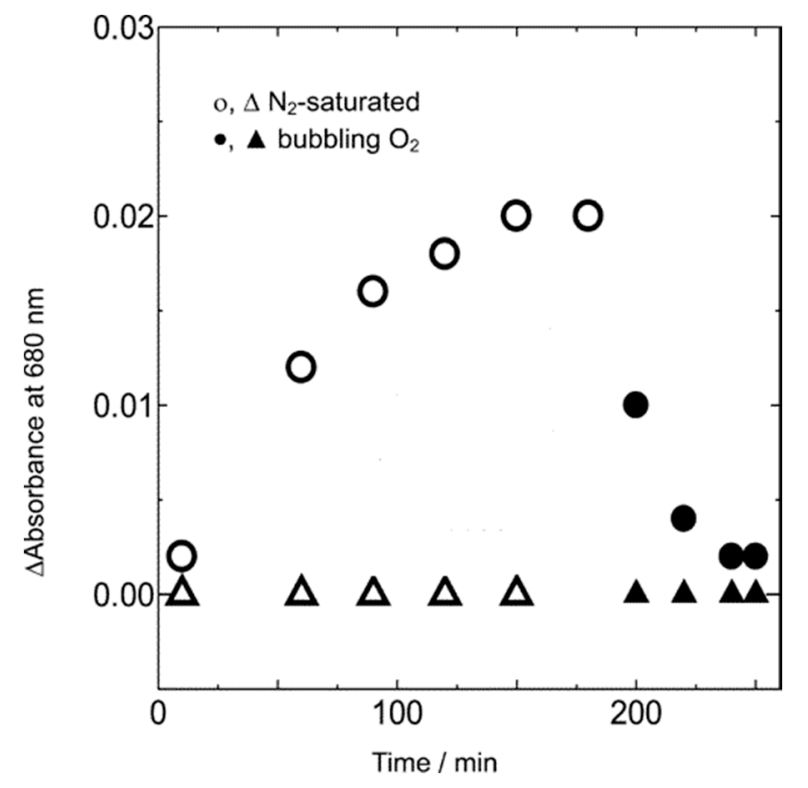

Figure 13. "Electron" absorption in $\mathrm{TiO}_{2} @ 680 \mathrm{~nm}$ induced by visible illumination $(\lambda>500 \mathrm{~nm})$ of $\mathrm{Au}$ deposits and its quenching by ambient $\mathrm{O}_{2}$ (adapted from [149]; copyright (2005) American Chemical Society).

In addition, the characteristic spectrum of self-trapped electrons in $\mathrm{TiO}_{2}\left(\lambda_{\max } \approx 680 \mathrm{~nm}\right)$ developed under $\mathrm{N}_{2}$. As shown in Figure 13, this was quenched in the presence of $\mathrm{O}_{2}$ as electron acceptor. More extensive studies on $\mathrm{Au} / \mathrm{TiO}_{2}$ and $\mathrm{Ag} / \mathrm{TiO}_{2}$ have reached similar conclusions but efficiencies still need 
improvement [150-154]. The theoretical basis of plasmonics is developing rapidly, but two distinct types of interaction have already been identified [155-159]. The first is "hot electron" transfer from the metal to the semiconductor, which is the LSPR-induced analogue of indirect charge injection from a sensitizer dye in the DSSC, as described above. A second mechanism is also operative if their respective absorption bands overlap. This is termed plasmon resonant energy transfer (PRET), but its directionality may be reversed under UV irradiation (semiconductor $\rightarrow$ metal) via Forster resonant energy transfer (FRET). These "near-field" effects do not even require electrical contact at the interface. Notable examples are long-lived hot electron injection from $\mathrm{Au}$ to $\mathrm{TiO}_{2}$ [160], PRET from insulated Ag nanocubes to N-doped $\mathrm{TiO}_{2}$ [161]; or PRET from $\mathrm{Au}$ to $\alpha-\mathrm{Fe}_{2} \mathrm{O}_{3}$ nanoplatelets [162]. Despite the promise of plasmonic sensitization, the long term economic outlook dictates a shift towards more earth abundant (but inevitably less stable) elements such as $\mathrm{Cu}$ [163-165], Al [166] and doped oxides [167].

\subsection{Individual Alternatives to $\mathrm{TiO}_{2}$}

Recent reviews affirm that applied photocatalysis research is still largely $(>80 \%)$ based on $\mathrm{TiO}_{2}$, albeit in increasingly sophisticated (modified) forms [168-170]. Being amenable to nano-architecturing [170], and providing multi-phase heterojunctions for improved charge separation [171,172], this benchmark material has close to ideal properties as a photocatalyst $[173,174]$ excepting its poor solar light response. One overdue task in $\mathrm{TiO}_{2}$ research is a more quantitative evaluation of the importance of trapping states that do not lead to fast recombination but, on the contrary, extend charge carrier lifetime into the seconds or minutes time domain [175-181]. Recent modeling studies on photoexcited anatase show that the energetics (site stability — surface vs. bulk) favour surface-trapping of both the hole and the electron [182], with beneficial implications for surface redox chemistry.

The search for visible-light active semiconductors that also satisfy other key criteria for practical photocatalysis on a large scale is a difficult task. While various alternative semiconductors exist with suitable bandgap $\left(\mathrm{Eg}_{\mathrm{g}}=1.5-3.0 \mathrm{eV}\right)$, most are inferior to $\mathrm{TiO}_{2}$ in other respects, e.g., in having lower majority carrier conductivity, shorter minority carrier diffusion length (faster recombination), a less positive valence band edge (lower oxidizing power), instability under illumination (photo-corrosion), toxicity and/or high cost [183]. For these reasons, emphasis is now shifting to the development of type II (staggered bandgap) composites or tandem arrangements that perform complementary functions, coupled by directional electron transfer at the common heterojunction to "close the photochemical circuit" (vide infra) [111,183].

One notable exception that has emerged recently is graphitic carbon nitride $\left(g-\mathrm{C}_{3} \mathrm{~N}_{4}\right)$, which has a similar bandgap to $\mathrm{N}^{-\mathrm{TiO}_{2}}(\mathrm{Eg} \approx 2.7 \mathrm{eV}$ - see also Figure 11), suitable energetics (band edge positions) for water splitting [142], and can be doped (bandgap tuned) and nano-textured to promote efficient charge migration [184-186]. However, a recent modeling study has identified a major kinetic constraint (large overpotential) linked to oxidative dissociation of water [187], helping to rationalize why co-catalysts are urgently needed for $\mathrm{O}_{2}$ evolution [188]. In contrast, modeling studies have shown that

$\mathrm{N}$-doping of anatase $\mathrm{TiO}_{2}$ may actually promote water dissociation [189].

Elsewhere, research into prospects for hematite $\left(\alpha-\mathrm{Fe}_{2} \mathrm{O}_{3}\right)$ has undergone a strong revival in the last decade, mainly due to efforts by the EPFL (Lausanne, Switzerland) group [162,183,190,191]. Pristine hematite is a cheap and stable indirect n-type semiconductor that absorbs visible light up to $\sim 600 \mathrm{~nm}$ 
$\left(E_{g}=1.9-2.2 \mathrm{eV}\right)$, offering a maximum photocurrent density of $12.6 \mathrm{~mA} \mathrm{~cm}{ }^{-2}$, or a solar-to-hydrogen (STH) conversion efficiency $(\eta \mathrm{STH})$ of $\sim 16 \%$. One limitation is its relatively low majority carrier (electron) conductivity, but this is readily overcome by incorporation of suitable dopants, e.g., $\mathrm{Ti}^{4+}, \mathrm{Sn}^{4+}$, $\mathrm{Nb}^{5+}$, etc. [192]. However, it also suffers from several more challenging (deleterious) properties as a photo(electro)catalyst. Having a conduction band edge too low in energy for proton reduction and a large overpotential for $\mathrm{O}_{2}$ evolution means water splitting over $\alpha-\mathrm{Fe}_{2} \mathrm{O}_{3}$ will only work under external bias [183,191,193]. Furthermore, its high optical absorption depth ( 400 nm [194]), coupled with a very short minority carrier (hole) diffusion length ( $\sim \mathrm{nm}$ [195]) translates into a very low quantum efficiency for charge collection (IPCE). Nevertheless, structuring highly-crystalline deposits on the 20-30 nm scale has already raised the IPCE to over $30 \%$ with photocurrent densities exceeding $3 \mathrm{~mA} \cdot \mathrm{cm}^{-2}[190,191,196,197]$. Reinforcing the contention that long-lived charge carriers are of key importance (vide ultra), application of transient optical and electrochemical techniques on $\alpha-\mathrm{Fe}_{2} \mathrm{O}_{3}$ photo-electrodes held under positive (anodic) bias has shown a quantitative correlation between accumulated surface-trapped holes and photocurrent (electron) density [198]. The hole lifetime $(\tau=0.1-1 \mathrm{~s})$ is sufficient for photo-oxidation of water, which has a rate constant in the range $0.1-10 \mathrm{~s}^{-1}[199,200]$. The holes are reported to be of two distinct types, $\mathrm{O}_{2 \mathrm{p}}\left(\mathrm{O}^{-}\right)$and $\mathrm{Fe}_{3 \mathrm{~d}}\left[\mathrm{Fe}^{\mathrm{n}+}(n>3)\right]$, but both have similar activity [201].

\subsection{Tandem (D4) Photoelectrochemical Cells, Composites, and the Role of Co-catalysts in Water Splitting}

It is 30 years ago now that visible light-driven electron transfer from $\mathrm{CdS}$ to $\mathrm{TiO}_{2}$ in an aqueous suspension of aggregated nanoparticles was first demonstrated [202]. The STH efficiency for the composite was very low but better than either of the pure components due to effective spatial separation and localization of electrons into $\mathrm{TiO}_{2}$ (for proton reduction), the holes remaining on $\mathrm{CdS}$ (for $\mathrm{H}_{2} \mathrm{~S}$ oxidation) due to the relative energetics of the respective band edges (type II-see Figure 5 [82]). Here, the particles act as complementary self-biasing "photoelectrochemical diodes" in an efficient S2 mechanism ( 2 photons per $\mathrm{H}_{2}$ molecule). Since that time, remarkable progress has been made in the visible-driven reduction half-reaction of water splitting:

$$
2 \mathrm{H}^{+}+2 \mathrm{e}^{-} \rightarrow \mathrm{H}_{2}\left[\mathrm{E}^{\circ}(\mathrm{V})=0.00-(0.059 \times \mathrm{pH})\right]
$$

A quantum yield of $93 \%$ was recorded over $\mathrm{Pt} / \mathrm{PdS} / \mathrm{CdS}$ at $420 \mathrm{~nm}$, evolving $9 \mathrm{mmol} / \mathrm{h} \mathrm{H}_{2}$ with sulphide/sulfite as sacrificial donors [203]. Conventional wisdom has it that the low levels of Pt (0.3\%) and $\mathrm{PdS}(0.13 \%)$ act as cocatalysts $[51,53,203,204]$. PdS is believed to promote oxidation of $\mathrm{S}^{2-}$ and $\mathrm{SO}_{3}{ }^{2-}$ and transfer electrons to $\mathrm{CdS}$. However, recent literature suggests that the combination of $\mathrm{PdS}$ and $\mathrm{CdS}$ may also be classified as an optical tandem system. PdS is an n-type semiconductor with a bandgap of $\sim 1.6 \mathrm{eV}$ and under investigation as a photovoltaic material per se [205,206]. It confers extra absorption in CdS composites that extends into the near IR region [207,208]. Unfortunately, the rarity of Pt and Pd, the tendency of sulphides to photocorrode, and the toxicity of cadmium ion, all militate against their use on a large scale. As shown in Figure 14, Pt as cocatalyst traps electrons from the semi- conductor to discharge protons, forming $\mathrm{Pt}-\mathrm{H}$ bonds of ideal (intermediate) strength for $\mathrm{H}-\mathrm{H}$ combination and desorption as molecular $\mathrm{H}_{2}$ (Sabatier Principle). While often black in appearance, co-catalysts are strictly not photoactive and promote only dark elementary steps in the reaction. As shown in Figure 15, there is 
an optimum amount due to competing (beneficial and deleterious) effects. In practice loadings fall below $1 \%$, fortuitously mitigating costs (many are precious metal-based, e.g., $\mathrm{IrO}_{2}, \mathrm{RuO}_{2}$, etc.) while minimizing parasitic light absorption. Prospects for alternative earth-abundant cocatalysts in photocatalytic water splitting have been reviewed [209]. Promising substitutes for $\mathrm{Pt}$ in $\mathrm{H}_{2}$ evolution under neutral or alkaline conditions are Ni nanoclusters [210], Ni/Mo alloy [211,212], and $\mathrm{Cu}(\mathrm{OH})_{2}[213]$.

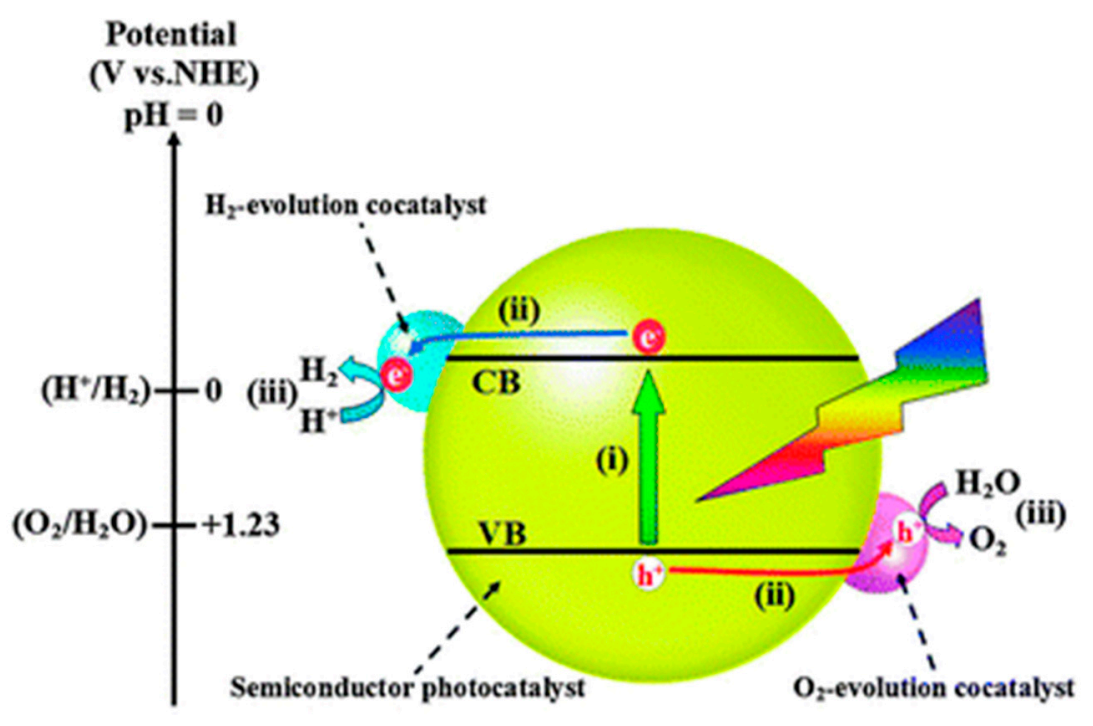

Figure 14. Photocatalytic water splitting over a visible-absorbing semiconductor loaded with $\mathrm{H}_{2}-\& \mathrm{O}_{2}$-evolution co-catalysts (reproduced from [209] with permission of the Royal Society of Chemistry).

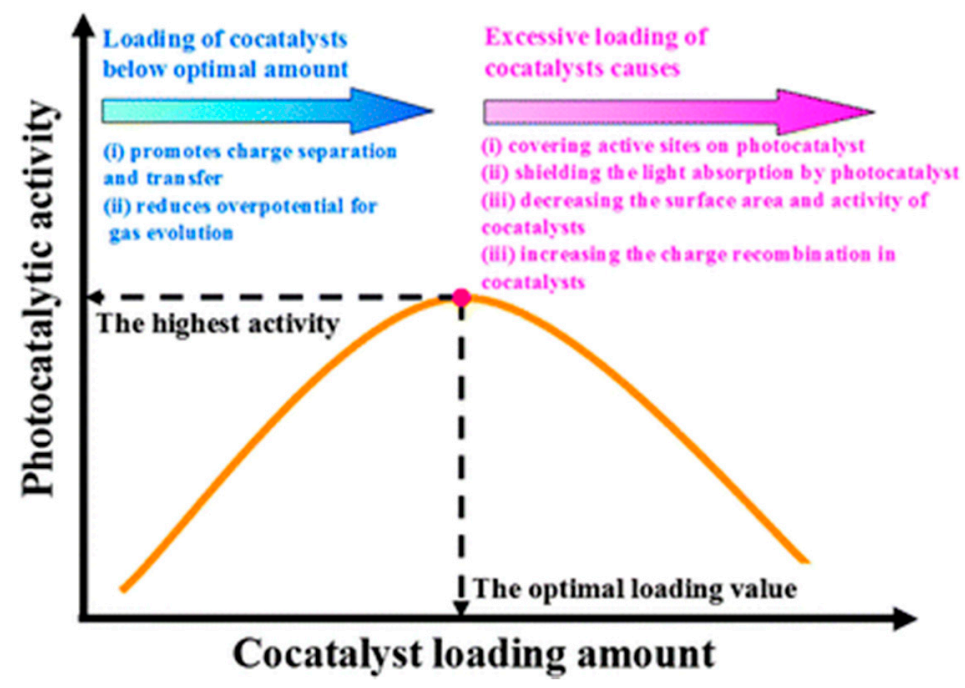

Figure 15. Principle of optimum loading of cocatalyst on a visible-absorbing semiconductor photocatalyst (reproduced from [209] with permission of the Royal Society of Chemistry).

The water oxidation half reaction [or oxygen evolution reaction (OER)]:

$$
2 \mathrm{H}_{2} \mathrm{O} \rightarrow \mathrm{O}_{2}+4 \mathrm{H}^{+}+4 \mathrm{e}^{-}\left[\mathrm{E}^{\circ}(\mathrm{V})=+1.23-(0.059 \times \mathrm{pH})\right]
$$

is the main obstacle to efficient water splitting as it suffers from a large activation energy barrier (overpotential $>0.4 \mathrm{~V}$ ) due to the necessary transfer of 4 charges per $\mathrm{O}_{2}$ molecule in a complex 
proton-coupled electron transfer mechanism [46,214]. Nature's catalyst in photosynthetic water oxidation is the $\mathrm{CaMn}_{4} \mathrm{O}_{\mathrm{x}}$ cubane-related molecular complex [215]. Traditionally, simple though expensive oxides like $\mathrm{RuO}_{2}$ and $\mathrm{IrO}_{2}$ have been used at the anode of PEM (acid) water electrolyzers [216], while mixed oxide $\mathrm{Ni}$ and $\mathrm{Co}$ spinels or perovskites (with inclusion of $\mathrm{Cu}$ ) are favoured in alkali electrolyzers [217]. In heterogeneous particulate systems, the earth-abundant oxide $\mathrm{CoO}_{\mathrm{x}}$ loaded onto $\mathrm{LaTiO}_{2} \mathrm{~N}$ had an OER quantum efficiency $\left(\Phi_{\mathrm{O} 2}\right)$ of $27 \%$ at $440 \mathrm{~nm}$ [218], while $\mathrm{CoO}_{\mathrm{x}}$ or $\mathrm{MnO}_{\mathrm{x}}$ on $\mathrm{TiO}_{2}$ nanosheets achieved $\Phi_{\mathrm{O} 2} \approx 15 \%$ at $365 \mathrm{~nm}$ [219]. In overall water splitting, only composite (tandem) absorbers, each optimized (with cocatalysts) for a single half-cell reaction have achieved quantum efficiencies greater than 5\% (vide infra). Most progress has been made with oxysulphides or oxynitrides of $\mathrm{d}^{\circ}$ or $\mathrm{d}^{1 \circ}$ metal cations $[107,220]$. It should also be noted that quantum efficiency $(\Phi)$ values are not to be mistaken for $\eta_{\mathrm{STH}}$. The last is theoretically $\sim 10 \%$ for an absorber with a $500 \mathrm{~nm}$ absorption cut-off even at $100 \%$ quantum efficiency $(\Phi=1)$. In reality, despite intensive efforts over the last three decades $\eta$ STH values for particulate systems have yet to exceed $1 \%$ [220,221].

Prospects for PEC cells look promising due to the efficient separation, collection and transport of photo-separated charges in a wired system. For most photoanodes, e.g., $\alpha-\mathrm{Fe}_{2} \mathrm{O}_{3}, \mathrm{WO}_{3}$, or other materials of more suitable bandgap $\left(\mathrm{E}_{\mathrm{g}}=1.4-2.0 \mathrm{eV}\right)$, the conduction band energy is so positioned that any injected electrons can only thermalize into the valence band of the photocathode, e.g., $\mathrm{TiO}_{2}$, where they effectively neutralize holes created by direct photo-excitation ( of $\mathrm{TiO}_{2}$ ). By analogy with photosynthesis, such a configuration is generally referred to as a Z-scheme as originally proposed for spatially separated photoelectrodes [75]. Since most electrons reaching the photocathode conduction band are from the photoanode sensitizer and undergo two successive excitation steps, the mechanism is said to be of type D4 (4 photons per $\mathrm{H}_{2}$ ), As shown in Figure 16 for a visible-absorbing $\mathrm{WO}_{3}$ photoanode, if bare $\mathrm{TiO}_{2}$ is replaced by a photoactive cathode (or a solar cell whose cathode is configured to evolve $\mathrm{H}_{2}$ ) the theoretical combined efficiency can rise substantially due to wider light harvesting. This is most notably so $\left(\eta_{\mathrm{STH}}>40 \%\right)$ in a series arrangement with an "in- front" photoanode $\left(\mathrm{E}_{\mathrm{g}} \sim 1.8 \mathrm{eV}\right)$ that absorbs visible wavelengths to evolve $\mathrm{O}_{2}$ from water. The transmitted near-IR light is incident on the solar cell ( $\mathrm{E}_{\mathrm{g}} \sim 0.95 \mathrm{eV}$ ), which provides a voltage bias for $\mathrm{H}_{2}$ evolution at the cathode (see Figure 17). The $\mathrm{Z}$ scheme principle has been extended to particulate systems but with limited success [50,107]. An added complexity here is the need to promote interparticle electron transfer using a redox mediator, e.g., $\mathrm{IO}_{3}{ }^{-} / \mathrm{I}^{-}$, in solution. However, this suffers from "chemical short-circuiting", i.e., competitive reactions between water and the mediator, and especially reaction of its oxidized form, necessarily present in excess, with product $\mathrm{H}_{2}$. Nevertheless, Maeda et al. [222] have reported a respectable overall quantum efficiency of $6.3 \%$ at $420 \mathrm{~nm}$ for a Pt-doped $\mathrm{ZrO}_{2}$-protected $\mathrm{TaON}$ "cathode" (for $\mathrm{H}_{2}$ evolution) suspended with $\mathrm{PtO}_{x}$-loaded $\mathrm{WO}_{3}$ as "anode" (for $\mathrm{O}_{2}$ evolution). Better prospects may lie in elimination of mediators and the development of "all-solid-state" Z-scheme analogues, i.e., composite particles with heterojunctions [223-225]. 


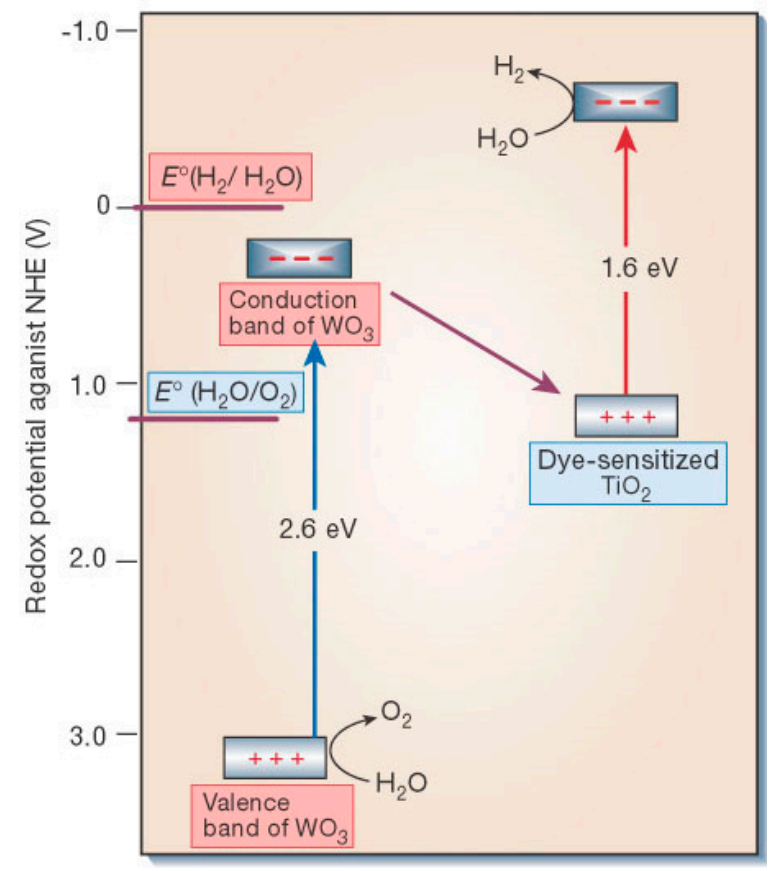

Figure 16. Example of Z-scheme (4D): $\mathrm{WO}_{3}$ photoanode $\left(\mathrm{E}_{\mathrm{cb}}<\mathrm{E}^{\circ} \mathrm{H}^{+} / \mathrm{H}_{2}\right)$ coupled to dye-sensitized $\mathrm{TiO}_{2}$ (reproduced from [76] with permission of the Nature Publishing Group).
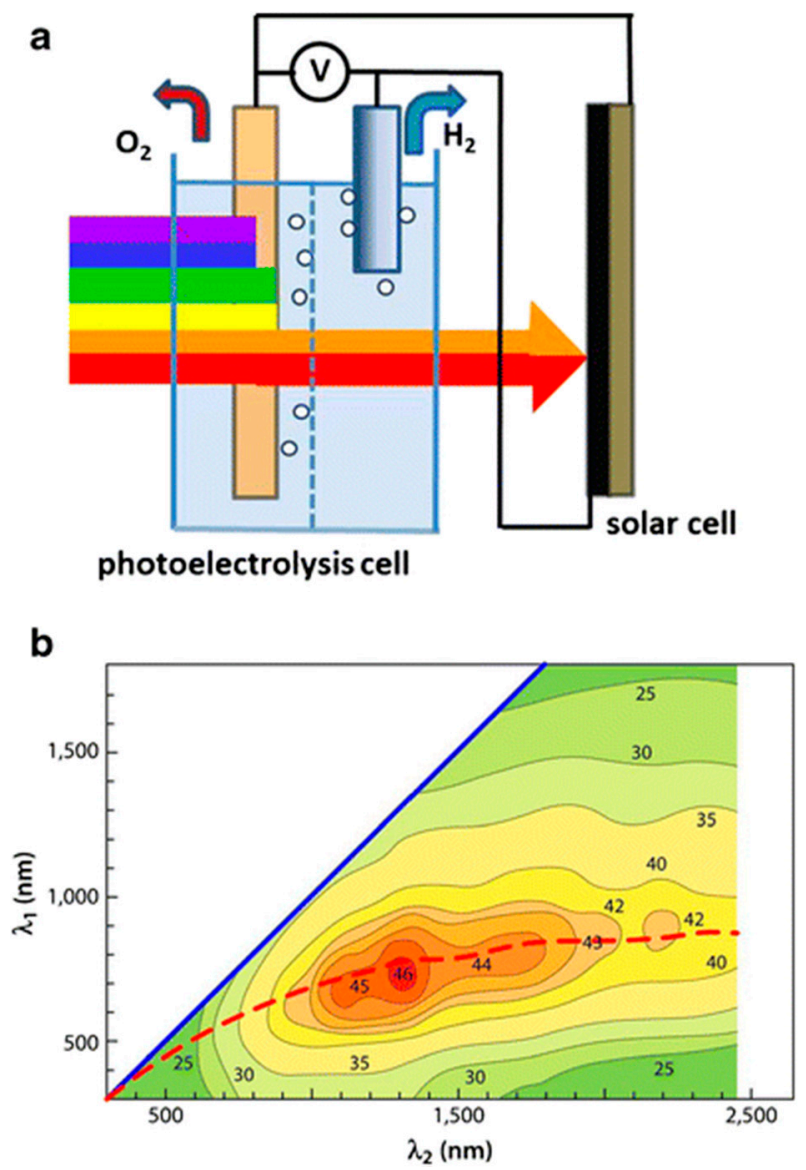

Figure 17. (a) Water splitting tandem cell: photoanode passes NIR light to solar cell, giving cathodic bias for $\mathrm{H}_{2}$ evolution; (b) Dual absorber efficiency curve ( $\eta_{\mathrm{STH}}>40 \%$ at $\lambda_{\mathrm{a}} \leq 750 \mathrm{~nm}$ $(1.6 \mathrm{eV}), \lambda_{\mathrm{sc}}=750-1300 \mathrm{~nm}(0.95 \mathrm{eV})$ (reproduced from [200] with permission from Springer). 
The choice of materials for practical tandem PEC cells is restricted. Figure 18 shows the bandgap and bend edge position of representative semiconductors. They must be cheap (earth-abundant) and stable ideally in strongly acidic and/or alkaline conditions for good electrolyte conductance.

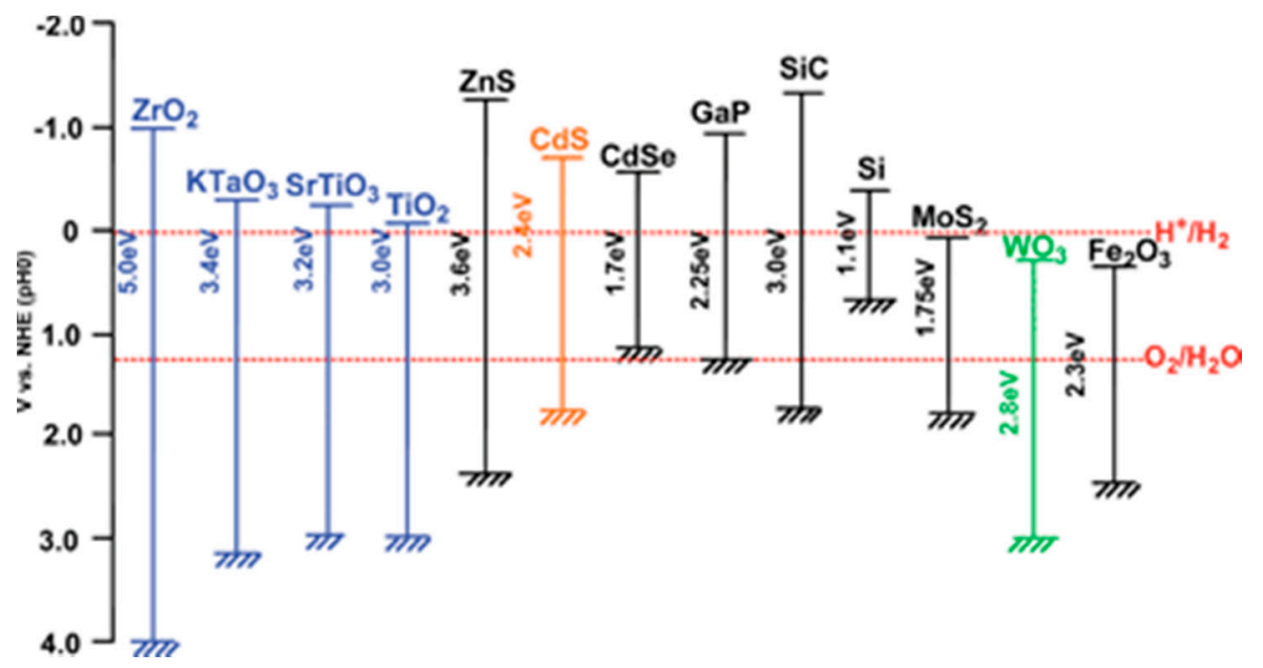

Figure 18. Bandgaps and band edge positions of representative semiconductors in relation to the redox potentials for water splitting at $\mathrm{pH}=0$. (Reproduced from [220] with permission of the Royal Society of Chemistry).

Bandgaps must also be higher to compensate for inevitable voltage losses, e.g., device series (ohmic) resistance, and electrode overpotentials. Nevertheless, the efficiencies of these tandem devices are expected to exceed 25\% [226,227]. Major advances towards this goal were reported by Nocera et al. $(\eta \mathrm{sTH}=4.7 \%, 2.5 \%$ wireless) [62] and Grätzel et al ( $\eta \mathrm{STH}=3.1 \%)[61]$, but with a quite different system approach. Nocera's design consisted of a triple-junction (T6 or 6-photon) amorphous Si absorber loaded with cobalt phosphate (for the oxygen evolution reaction-OER) [228]) and Ni/Mo alloy (for $\mathrm{H}_{2}$ evolution [211,212]) on a Ni mesh in phosphate or borate/nitrate buffer. The wireless layout suffered from an added resistance loss due to the longer migratory path imposed on proton transport from the front (anode) to the rear (cathode) of the cell. Grätzel's design was based on a single $\mathrm{WO}_{3}\left(\mathrm{Fe}_{2} \mathrm{O}_{3}\right)$ photoanode coupled to a single DSSC, as shown in Figures 16 and 17. It is not clear if only $\mathrm{Fe}_{2} \mathrm{O}_{3}$ or both were loaded with $\mathrm{IrO}_{2}$ co-catalyst. Continuing their exploration of a buried junction PV configuration with loaded electrocatalysts (EC), in which the $\mathrm{Si}$ absorber is protected from the electrolyte, the Nocera team most recently achieved $\eta_{\mathrm{STH}}=10 \%$ with these so-called PV-EC tandem devices [78]. It consists of 4 single-junction crystalline Si solar cells connected in series to a NiMo cathode and a nickel borate anode, all immersed in a borate buffer ( $\mathrm{pH}$ 9.2). The Ni-based anode is comparable in performance and cheaper than cobalt phosphate, but needs prior anodization (after deposition) to create the mixed-oxidation $\mathrm{Ni}^{\mathrm{III} / \mathrm{IV}}$ state responsible for OE activity [229]. However, both $\mathrm{Ni}$ and Co salts can be electrodeposited, conveniently forming the anode in-situ from divalent ions in the appropriate buffer. The latest efficiency advance reported by the Grätzel team is $\eta_{\mathrm{STH}}=12.3 \%$ in an analogous PV-EC device [77]. This was achieved with two DSSCs connected in series, each providing a short-circuit photocurrent density of $21.3 \mathrm{~mA} \cdot \mathrm{cm}^{-2}$, open-circuit voltage $\left(\mathrm{V}_{\mathrm{oc}}\right)=1.06 \mathrm{~V}$, and a fill factor of 0.76 . A combined solar-to-electric power conversion efficiency of $15.7 \%$ was attained with superior light harvesting by lead iodide perovskite $\left(\mathrm{CH}_{3} \mathrm{NH}_{3} \mathrm{PbI}_{3}\right)$ sensitizers, prepared using a simple 
two-step spin-coating method at $100{ }^{\circ} \mathrm{C}$. A cheap Ni-foam supported Ni/Fe layered double hydroxide, obtained by one-step hydrothermal growth, served as both cathode and anode in $1 \mathrm{M} \mathrm{NaOH}$ electrolyte. It should be noted that a comparable performance may be obtained in PV-driven ("brute force") electrolysis, i.e., by combining state-of-the-art PV modules and electrolyzers optimized independently. For example, $\eta_{\mathrm{sTH}} \approx 12 \%$ has been reported in standalone systems where the voltage was maintained at $\sim 1.7 \mathrm{~V}$ per cell (in a 20 cell PEM electrolyzer stack) with a DC-DC converter [230,231]. The PEC cell is a less expensive single integrated unit, provides a higher open circuit photovoltage, and reduces potential loss channels. However, it is susceptible to electrolyte resistance and polarization losses [227,232], especially under neutral conditions needed for operational stability of many earth-abundant co-catalysts. In view of such complications and exciting results with hybrid (PV-EC) devices, co-development of PV-electrolyzers and PEC water splitting cells may offer the best prospects [233,234].

\section{Hydrogen Peroxide as Solar Fuel and Sustainable Chemical}

Water splitting to $\mathrm{H}_{2}$ and $\mathrm{O}_{2}$ has been considered the "Holy Grail" of chemists working in the energy field. However, the co-production of $\mathrm{H}_{2}$ and $\mathrm{H}_{2} \mathrm{O}_{2}$ is arguably a yet more valuable process:

$$
2 \mathrm{H}_{2} \mathrm{O} \rightarrow \mathrm{H}_{2}+\mathrm{H}_{2} \mathrm{O}_{2}\left[\Delta \mathrm{G}^{\circ}=+342 \mathrm{~kJ} / \mathrm{mol} \mathrm{H}_{2} \mathrm{O}_{2}\right]
$$

and may actually be easier, i.e., the kinetic barrier may be lower, because it is just a $2 \mathrm{e}^{-}$process:

$$
2 \mathrm{H}_{2} \mathrm{O} \rightarrow 2 \mathrm{H}^{+}+2 \mathrm{e}^{-}+\mathrm{H}_{2} \mathrm{O}_{2}\left[\mathrm{E}^{\circ}=-1.77 \mathrm{~V}\right]
$$

This requires two photons at $171 \mathrm{~kJ} / \mathrm{mol}$ (photons), corresponding to wavelengths below $\sim 690 \mathrm{~nm}$, which comprises $\sim 50 \%$ of the solar power spectrum. Hydrogen peroxide is a valuable commodity chemical serving as a green oxidant in environmental clean-up, pulp bleaching, detergents, etc. [235]. It is now made largely by the Anthraquinone Process but research has intensified in recent years into direct catalytic synthesis from $\mathrm{H}_{2}$ and $\mathrm{O}_{2}$ :

$$
\mathrm{H}_{2}+\mathrm{O}_{2} \rightarrow \mathrm{H}_{2} \mathrm{O}_{2}
$$

which is exothermic $\left(\Delta \mathrm{H}^{\circ}=-136 \mathrm{~kJ} / \mathrm{mol}\right)$ and a competitive option for small-scale on-site production $\left(<10^{4} \mathrm{t} / \mathrm{y}\right)$ [236,237]. However, it deals with potentially explosive mixtures and only works efficiently over expensive rare metal $(\mathrm{Pd}$ or $\mathrm{Pd} / \mathrm{Au})$ catalysts. It is also an example of a highly selective partial oxidation reaction in which reaction with a second $\mathrm{H}_{2}$ molecule:

$$
\mathrm{H}_{2} \mathrm{O}_{2}+\mathrm{H}_{2} \rightarrow 2 \mathrm{H}_{2} \mathrm{O}_{(\mathrm{g})}
$$

is even more exothermic (Equation (10) is the reverse of Equation (7)) and must be kinetically inhibited [238]. A $\mathrm{PtHg}_{4} / \mathrm{C}$ electrocatalyst was shown to be active and highly selective for $\mathrm{H}_{2} \mathrm{O}_{2}$ synthesis, as predicted by DFT modeling [239]. Alloying leaves an isolated surface Pt atom for hydroperoxide ( $\mathrm{HOO}^{*}$ ) stabilization in the on-top position while eliminating the hollow adsorption sites preferred by activated oxygen $\left(\mathrm{O}^{*}\right)$ species, thereby inhibiting water as product. Unfortunately, it is still a rare-metal based formulation. The cathodic half-cell reacton for peroxide synthesis from water (Equation (8)) can be written in two ways depending on the electron acceptor.

For co-production of $\mathrm{H}_{2}$ (Equation (7) overall) this is:

$$
2 \mathrm{H}^{+}+2 \mathrm{e}^{-} \rightarrow \mathrm{H}_{2}\left[\mathrm{E}^{\circ}=0.00 \mathrm{~V}\right]
$$


However, peroxide can also be synthesized by $\mathrm{O}_{2}$ reduction:

$$
\mathrm{O}_{2}+2 \mathrm{H}^{+}+2 \mathrm{e}^{-} \rightarrow \mathrm{H}_{2} \mathrm{O}_{2}\left[\mathrm{E}^{\circ}=0.68 \mathrm{~V}\right]
$$

Summing the two half reactions (8) and (12), each yielding one peroxide molecule, gives Equation (13):

$$
2 \mathrm{H}_{2} \mathrm{O}+\mathrm{O}_{2} \rightarrow 2 \mathrm{H}_{2} \mathrm{O}_{2}\left[\mathrm{E}^{\circ}=-1.09 \mathrm{~V}\right]
$$

This is still a potentially visible-driven endergonic process so that $\mathrm{H}_{2} \mathrm{O}_{2}$ alone can be considered as an energy carrier derivable from cheap reactants. Supplied commercially as $30 \%$ aqueous solution ( 9M) it is already in an energy dense form, unlike $\mathrm{H}_{2}$ gas, and this underlines recent interest in peroxide as a solar fuel. Having acceptor and donor properties (reverse of Equations (8) and (12), respectively), the theoretical voltage of a "direct $\mathrm{H}_{2} \mathrm{O}_{2}$ " fuel cell based on its own dismutation (reverse of Equation (13)) is $1.09 \mathrm{~V}$. Although it enables a simplified fuel cell design (use of a single compartment is possible), the current densities are not yet of technical interest [240-246]. Alternatively, as a more powerful oxidant (than $\mathrm{O}_{2}$ ) supplied to the cathode, it increases the operating voltage in cells based on $\mathrm{H}_{2}$ [247] or liquid fuels such as aqueous $\mathrm{NaBH}_{4}$ [248,249] and ethanol [250]. However, its powerful oxidizing properties and susceptibility to decomposition by traces of metal (ions) and redox-active surfaces can also lead to under-performance (mixed potentials) and introduces more stringent material compatibility issues, especially concerning long-term stability of polymer membranes and possibly carbon as an electrocatalyst support. Potential cathode materials explored to date include $\mathrm{PbSO}_{4}$ [240], Au on Vulcan [249], and $\mathrm{LaNiO}_{3}$ on N-doped graphene, which promotes the ORR [251].

In energetic terms, the photosynthetic route involving co-generation of hydrogen (Equation (7)) would be preferred as long as the $\mathrm{H}_{2} \mathrm{O}_{2} / \mathrm{H}_{2}$ mixture remains stable. This has been reported for platinized calcium niobate [252] and $\mathrm{Pt} / \mathrm{TiO}_{2}$ [253]. Both showed relatively low quantum efficiencies $\left(\Phi_{\mathrm{uv}}<1 \%\right)$ but the 1:1 product stoichometry of Equation (7) was confirmed. A liquid water environ-ment would probably impede further reaction because any $\mathrm{H}_{2} \mathrm{O}_{2}$ dissolves selectively. However, little peroxide was found in solution, most remaining associated with the catalyst in a form seemingly immune to any back-reaction with $\mathrm{H}_{2}$. This is consistent with previous literature showing that, in the absence of $\mathrm{O}_{2}$, a stable form of peroxide $\left(\mathrm{O}_{2}{ }^{2-}, \mathrm{HO}_{2}{ }^{-}\right.$, etc. $)$builds up and deactivates the photo-process in a few hours, typically affording only micromoles of products. Although the intermediate(s) can be decomposed easily to yield $\mathrm{O}_{2}$ (the "missing" product in early studies of water splitting [254,255]), a way must be found to displace it as intact $\mathrm{H}_{2} \mathrm{O}_{2}$, e.g., by exploring more weakly-adsorbing (non-oxide) semiconductors and/or loading an oxidation co-catalyst. A viable system needs to sustain millimoles per hour productivity indicative of a broad spectral response and quantum yields exceeding 10\%. This may be achievable but not easily recognized in practice because the peroxide, once formed, can decompose adventitiously, e.g., in the presence of trace metal ions, or excited by the UV component of a solar simulator, etc. $\mathrm{Such}_{2} \mathrm{O}_{2}$ production rates $\left(\Phi_{\mathrm{uv}}=1 \%-30 \%\right)$ have been reported over quantum-sized $\mathrm{ZnO}$ and $\mathrm{TiO}_{2}$ particles but only under oxygenated conditions, implying that photo-reduction of $\mathrm{O}_{2}$ (Equation (12)) is the main source of peroxide [256]. Fluorination of $\mathrm{TiO}_{2}$ improved dramatically the yield by weakening the surface adsorption of peroxide, a precursor step in self-decomposition [257]. 

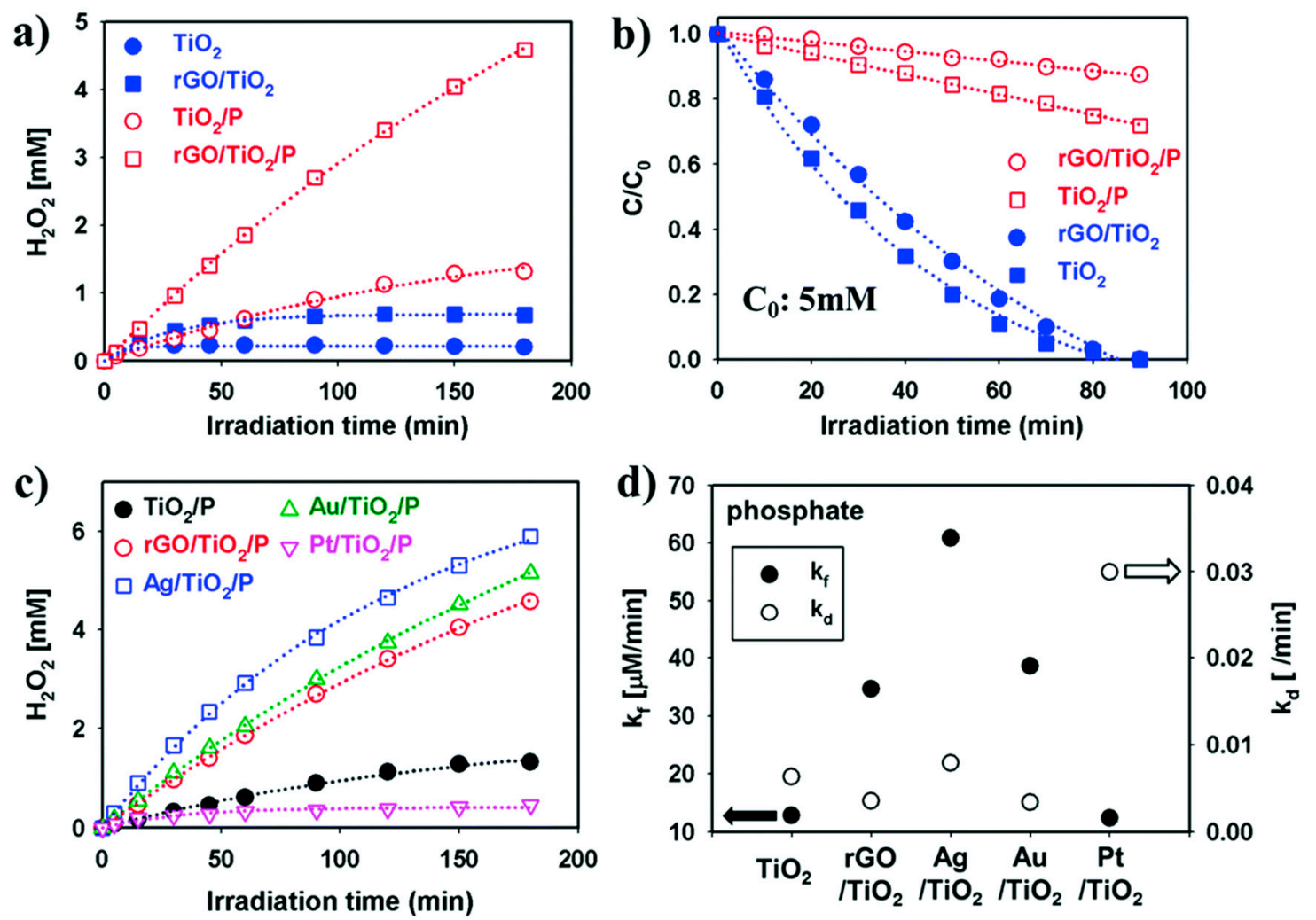

Figure 19. (a) Effect of pre-treating $\mathrm{TiO}_{2}$ with phosphate on $\mathrm{H}_{2} \mathrm{O}_{2}$ photosynthesis $(\lambda>320 \mathrm{~nm})$, and (b) $5 \mathrm{mM} \mathrm{H}_{2} \mathrm{O}_{2}$ decomposition over $6 \mathrm{wt} \% \mathrm{rGO} / \mathrm{TiO}_{2}(0.5 \mathrm{~g} / \mathrm{L})$ in $\mathrm{O}_{2}$-saturated aqueous buffer ( $\mathrm{pH} 3$ ) containing 5 vol \% 2-propanol as hole scavenger; (c) Comparison of $\mathrm{H}_{2} \mathrm{O}_{2}$ synthesis rates over $\mathrm{rGO} / \mathrm{TiO}_{2}(\mathrm{P})$ and $1 \mathrm{wt} \%$ metalized $\mathrm{TiO}_{2}(\mathrm{P})$ samples; (d) Rate constants of $\mathrm{H}_{2} \mathrm{O}_{2}$ synthesis $\left(\mathrm{k}_{\mathrm{f}}\right)$ and decomposition $\left(\mathrm{k}_{\mathrm{d}}\right)$ over $\mathrm{TiO}_{2}(\mathrm{P})$-supported composites (reproduced from [258] with permission of the Royal Society of Chemistry).

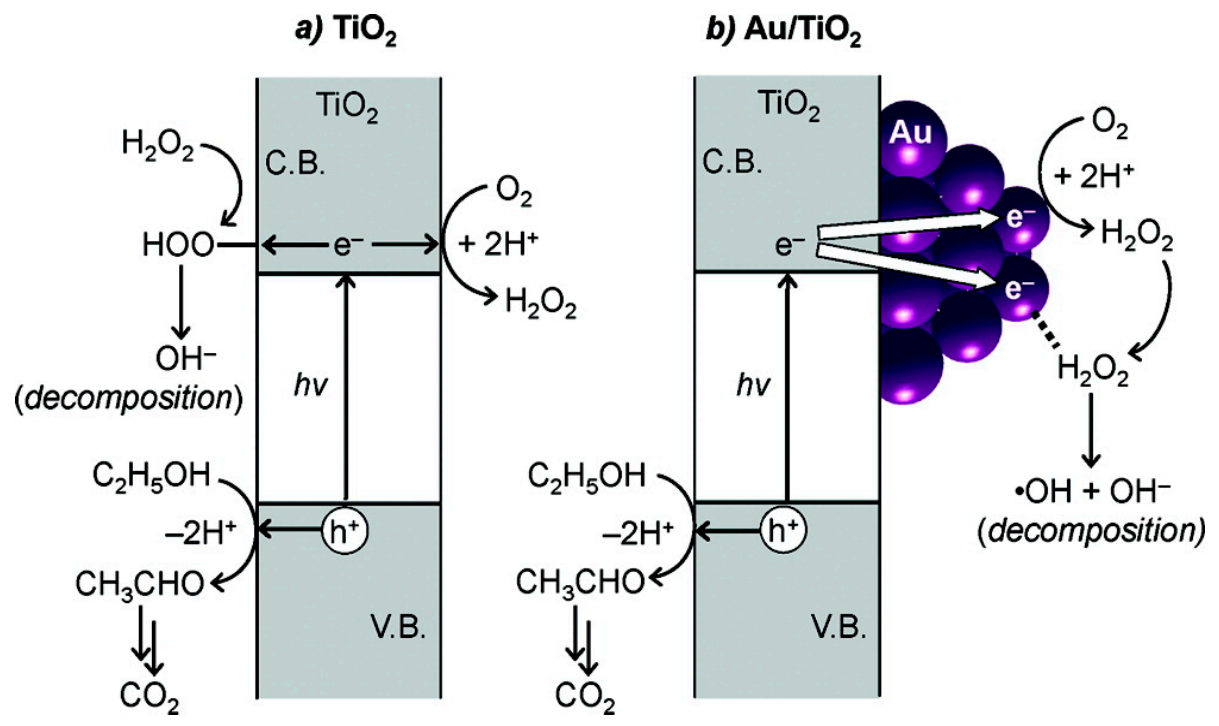

Figure 20. Scheme of synthesis and decomposition of $\mathrm{H}_{2} \mathrm{O}_{2}$ on (a) $\mathrm{TiO}_{2}$; and (b) $\mathrm{Au} / \mathrm{TiO}_{2}$ photocatalysts. (Reproduced from [259]. Copyright (2012) American Chemical Society). 


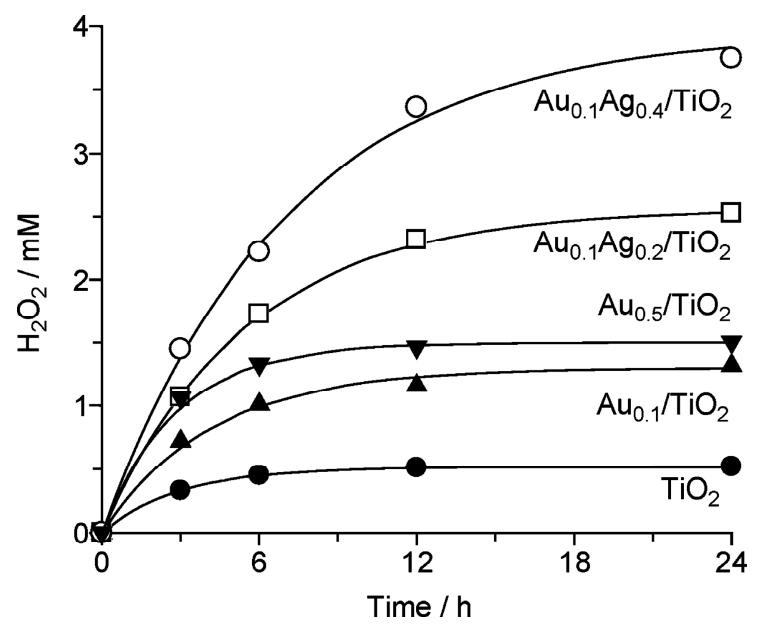

Figure 21. Build-up of photostationary levels of $\mathrm{H}_{2} \mathrm{O}_{2}$ on $\mathrm{Au}-\mathrm{Ag} / \mathrm{TiO} 2$ catalysts $(5 \mathrm{mg})$ in $5 \mathrm{~mL}$ aerated $4 \%$ aqueous ethanol $\left(\lambda>280 \mathrm{~nm}, \mathrm{I}_{\mathrm{uv}} \approx 14 \mathrm{~mW}\right)$ ). (Reproduced from [259]. Copyright (2012) American Chemical Society).

As shown in Figure 19, the same effect was seen in a reduced graphene oxide ( $\mathrm{rGO}) / \mathrm{TiO}_{2}$ composite in which the $\mathrm{TiO}_{2}$ surface was phosphated to prevent simultaneous degradation, which is otherwise responsible for the attainment of photostationary product levels [258]. Alternatively, as shown in Figures 20 and 21, alloying $\mathrm{Au}$ (on $\mathrm{TiO}_{2}$ ) with $\mathrm{Ag}$ suppresses selectively the intrinsic tendency of $\mathrm{Au}$ to simultaneously decompose its own product, thereby raising photostationary yields [259]. In contrast, it has been reported that $\mathrm{TiO}_{2}$ per se is a poor catalyst in $\mathrm{H}_{2} \mathrm{O}_{2}$ decomposition due to its low affinity for the $\mathrm{OH} \cdot$ radical $[260,261]$. This powerful but non-selective oxidant:

$$
\mathrm{HO}^{\bullet}+\mathrm{H}^{+}+\mathrm{e}^{-} \rightarrow \mathrm{H}_{2} \mathrm{O}\left[\mathrm{E}^{\circ}=2.80 \mathrm{~V}\right]
$$

is produced from hydrogen peroxide by an electron donor:

$$
\mathrm{H}_{2} \mathrm{O}_{2}+\mathrm{H}^{+}+\mathrm{e}^{-} \rightarrow \mathrm{HO}^{\bullet}+\mathrm{H}_{2} \mathrm{O}\left[\mathrm{E}^{\circ}=0.72 \mathrm{~V}\right]
$$

uch as $\mathrm{Fe}^{2+}$ in the Photo-Fenton process, one of a variety of advanced oxidation processes (AOP) [13,96,262]. Unfortunately, it also promotes the autocatalytic decomposition of peroxide [263]:

$$
\begin{gathered}
\mathrm{H}_{2} \mathrm{O}_{2}+\mathrm{OH}^{\cdot} \rightarrow \mathrm{H}_{2} \mathrm{O}+\mathrm{HO}_{2} \cdot\left[\mathrm{E}^{\circ}=1.40 \mathrm{~V}\right] \\
\mathrm{HO}_{2}{ }^{\circ} \rightarrow \mathrm{O}_{2}+\mathrm{H}^{+}+\mathrm{e}^{-}\left[\mathrm{E}^{\circ}=-0.05 \mathrm{~V}\right]
\end{gathered}
$$

Hole scavengers $\left(\mathrm{H} \cdot\right.$ donors) always increase decomposition rates, suggesting that the $2 \mathrm{e}^{-}$water oxidation half-reaction (Equation (8)) is rate-determining in the synthesis. Under these conditions, i.e., with little $\mathrm{H}_{2}$ or $\mathrm{H}_{2} \mathrm{O}_{2}$ produced from water, the process is of no interest as an energy conversion scheme. Nevertheless, the peroxide can still be considered a value-added green reagent obtained efficiently and cheaply by photo-oxidation of organic wastes. Evidence has just been reported for visible-driven $\mathrm{H}_{2} \mathrm{O}_{2}$ photosynthesis from oxygenated ethanol over pristine g- $\mathrm{C}_{3} \mathrm{~N}_{4}$ [264], whose conduction band minimum $\left(\mathrm{E}^{\circ} \approx-1.3 \mathrm{~V}[265]\right)$ exceeds the reduction potential for the $\mathrm{O}_{2} / \mathrm{O}_{2}{ }^{-}$couple $\left(\mathrm{E}^{\circ} \approx-0.3 \mathrm{~V}[266]\right)$. A 1,4-endoperoxide intermediate stabilized by the $\mathrm{g}-\mathrm{C}_{3} \mathrm{~N}_{4}$ surface was identified by Raman spectroscopy. Addition of $\mathrm{Pt}$ had a deleterious effect on yield due to its tendency to break the $\mathrm{O}-\mathrm{O}$ bond [239]. 


\section{Photoreforming of Bio-Oxygenates}

In the renewable energy scheme under consideration ( $c f$. Figure 1), bio-oxygenates like sugars, alcohols, and polyols, all serve as $\mathrm{CO}_{2}$-neutral energy carriers provided that their incipient $\mathrm{H}_{2}$ can be extracted efficiently by catalytic reforming with steam $[31,32,55,56]$ :

$$
\mathrm{C}_{\mathrm{n}} \mathrm{H}_{\mathrm{m}} \mathrm{O}_{\mathrm{k}}+(2 \mathrm{n}-\mathrm{k}) \mathrm{H}_{2} \mathrm{O} \rightarrow \mathrm{n} \mathrm{CO} 2+\left(2 \mathrm{n}+\mathrm{m}_{2}-\mathrm{k}\right) \mathrm{H}_{2}
$$

Despite being highly endothermic, Equation (18) is favoured thermodynamically above a threshold temperature due to the large volume expansion (entropy factor). Input thermal energy is converted into chemical energy $\left(\mathrm{H}_{2}\right)$ and represents a significant gain in exergy $(20 \%-30 \%)$, as can be seen by comparing the heats of combustion of reactant and product. This is known as "chemical recuperation" [267,268], and pre-reforming of natural gas is likely to be incorporated into future gas turbine technologies [269]. Methanol is not currently made on a large scale from biomass or renewable $\mathrm{H}_{2}$ and can be readily reformed by conventional (thermal) catalysis [23-25,28]. In contrast, ethanol comprises $90 \%$ of biofuel production and, due to its high growth forecast [270], is now being considered as a renewable platform chemical, e.g., for butadiene synthesis [271]. Ethanol is also a good model oxygenate as it is one of the simplest compounds containing $\mathrm{C}-\mathrm{C}, \mathrm{C}-\mathrm{H}$, and $\mathrm{C}-\mathrm{O}$ bonds. However, its catalytic conversion in high activity and selectivity poses a major challenge [272,273].

Bio-ethanol obtained by fermentation of glucose:

$$
\mathrm{C}_{6} \mathrm{H}_{12} \mathrm{O}_{6} \rightarrow 2 \mathrm{CO}_{2}+2 \mathrm{C}_{2} \mathrm{H}_{5} \mathrm{OH}
$$

is an excellent energy carrier since almost the entire heating value of the original sugar $(\sim 2800 \mathrm{~kJ} / \mathrm{mol})$ is retained in the product (two moles liquid ethanol at $1365 \mathrm{~kJ} / \mathrm{mol}$ ). Ethanol steam reforming (ESR):

$$
\mathrm{C}_{2} \mathrm{H}_{5} \mathrm{OH}(\mathrm{g})+3 \mathrm{H}_{2} \mathrm{O}(\mathrm{g}) \rightarrow 2 \mathrm{CO}_{2}+6 \mathrm{H}_{2}\left[\Delta \mathrm{H}^{\circ}=+174 \mathrm{~kJ} / \mathrm{mol}\right]
$$

raises the fuel value substantially ( six moles $\mathrm{H}_{2}$ at $286 \mathrm{~kJ} / \mathrm{mol}$ ). In addition, Equation (20) has a crossover $\left(\Delta \mathrm{G}^{\circ} \leq 0\right)$ temperature as low as $210{ }^{\circ} \mathrm{C}$ [19], suggesting it could be driven by "low-quality" heat provided a suitable catalyst can be found. This explains the major interest in ESR in recent years, e.g., as an on-board source of $\mathrm{H}_{2}$ for PEM fuel cell (electric) vehicular propulsion [274,275]. However, the low rates encountered over many oxide-supported transition metals ( $\mathrm{Pt}, \mathrm{Ni}, \mathrm{Co}, \mathrm{Rh}, \mathrm{Ru}$ ) necessitate working above $400{ }^{\circ} \mathrm{C}$, where rapid deactivation by coking ensues, possibly linked to acetic acid intermediate [30,276-278]. DFT modeling supports experimental data showing that the rate-determining step in ESR is initial dehydrogenation to acetaldehyde [279]:

$$
\mathrm{C}_{2} \mathrm{H}_{5} \mathrm{OH}_{\text {liq }} \rightarrow \mathrm{CH}_{3} \mathrm{CHO}+\mathrm{H}_{2}\left[\Delta \mathrm{H}^{\circ}=+85 \mathrm{~kJ} / \mathrm{mol}\right]
$$

a modestly endothermic reaction but with an apparent activation energy ( $\left.\mathrm{E}_{\mathrm{app}}\right)$ as high as $+150 \mathrm{~kJ} / \mathrm{mol}$ [280,281]. This is typically followed by decarbonylation of the aldehyde [281,282]:

$$
\mathrm{CH}_{3} \mathrm{CHO} \rightarrow \mathrm{CO}+\mathrm{CH}_{4}\left[\Delta \mathrm{H}^{\circ}=+7 \mathrm{~kJ} / \mathrm{mol}\right]
$$

an almost thermoneutral process giving an undesirable alkane product. Photocatalysis may circumvent these activity/selectivity issues because it works by an alternate mechanism (lowering Eapp) and at low temperature where deleterious side reactions are inhibited. The pioneering work of Pichat et al. [283,284] established that photo-dehydrogenation (PDH) of alcohols (see Equation (21)) proceeds in high quantum 
efficiency $\left(\Phi_{\mathrm{uv}} \geq 0.1\right)$ over $\mathrm{Pt} / \mathrm{TiO}_{2}$. More recently, photo-assisted water-gas shift (WGS) [285], photoreforming of methanol [286,287], and combined photo-/thermal reforming of methanol (or glycerol) to $\mathrm{H}_{2} / \mathrm{CO}_{2}$ co-products over $\mathrm{Pt} / \mathrm{TiO}_{2}$ [288] (or $\mathrm{Pd} / \mathrm{TiO} 2$ [289]) have been studied. As shown in Figures 22 and 23, mild heating is a useful adjunct in photocatalysis when dark processes are rate-controlling. However, despite the sharp rise $(\times 2-\times 5)$ in quantum efficiency $\left(\Phi_{\mathrm{uv}} \approx 7 \%\right.$ for $\mathrm{CH}_{3} \mathrm{OH}$ at $65{ }^{\circ} \mathrm{C}$ [288]) and better reaction stability (due to more complete product recovery [288,290]), this synergism has still not been widely exploited.

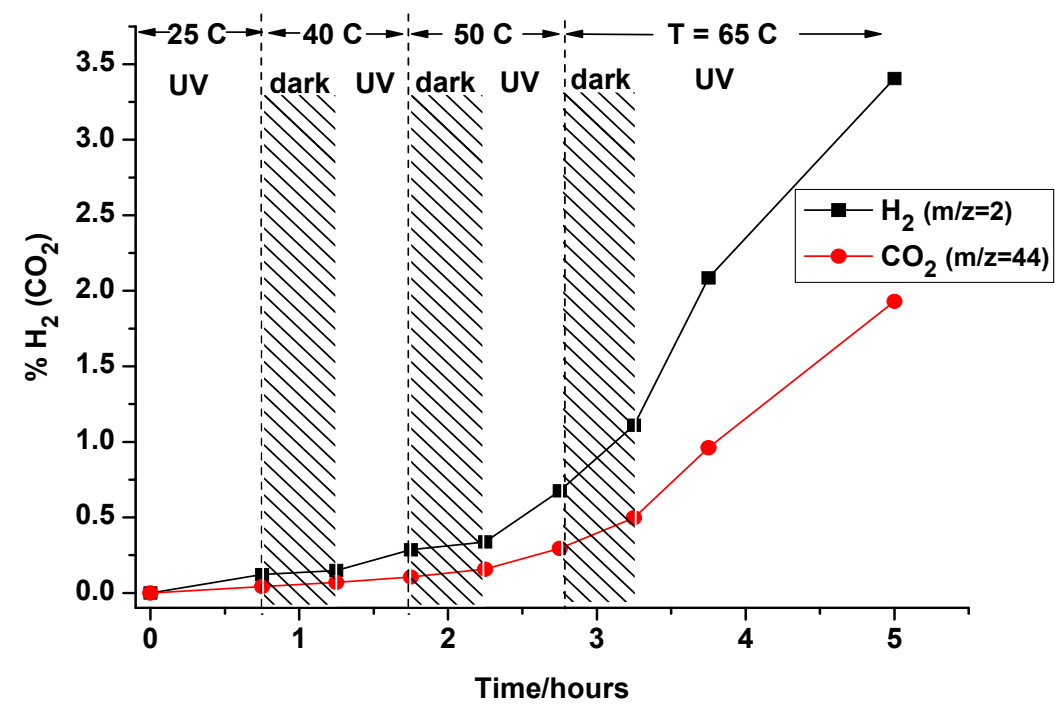

Figure 22. $\mathrm{MS}$ response $\left(\mathrm{H}_{2} / \mathrm{CO}_{2}\right)$ showing effect of temperature on rate of vapour-phase $\mathrm{CH}_{3} \mathrm{OH}$ photoreforming over $\mathrm{Pt} / \mathrm{TiO}_{2}$ (reproduced from [288] with permission of RSC).

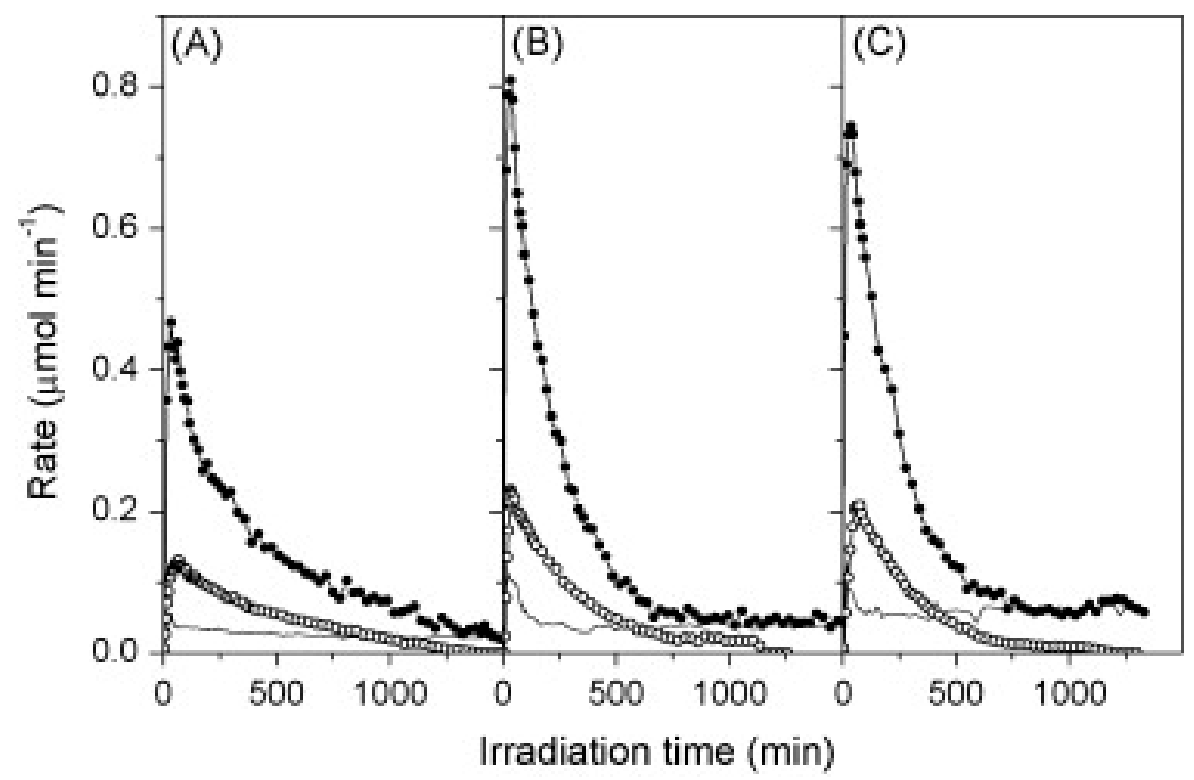

Figure 23. $\mathrm{H}_{2}$ (full circles) \& $\mathrm{CO}_{2}$ (closed circles) evolution during liquid-phase $(0.37 \mathrm{mM})$ aqueous glycerol reforming at (A) $40^{\circ} \mathrm{C}$; (B) $60^{\circ} \mathrm{C}$; (C) $80{ }^{\circ} \mathrm{C}$ (reproduced from [291] with permission of Elsevier). 
Photoreforming per se has been extended to ethanol [290-294], various alcohol mixtures [35,294-298], glycerol [33,55,56,289,299], sugars [300,301], and acetic acid [302]. In the last case, no $\mathrm{CH}_{4}$ product was seen, an encouraging result in view of previous claims of a novel Photo-Kolbé process over a similar catalyst [303]. All these studies used $\mathrm{TiO}_{2}$-supported precious metals responding only to UV light at high efficiency. For $80 \%$ aqueous ethanol over a well-dispersed $\mathrm{Pt} / \mathrm{TiO}_{2}$ film at low light intensities ( $\mathrm{I}_{\mathrm{uv}} \approx 0.8 \mathrm{~mW} / \mathrm{cm}^{2}$, or 0.2 suns), a remarkable quantum efficiency ( $\Phi_{\mathrm{uv}} \approx 74 \%$ ) was estimated [294]. Close to solar intensities, these were rather lower $\left(\Phi_{\mathrm{uv}}=10 \%-30 \%\right)$ for ethanol [290,295,297], but several groups have reported mass-specific $\mathrm{H}_{2}$ evolution rates of technical interest ( $\left.>2 \mathrm{mmol} / \mathrm{h} / \mathrm{g}_{\text {cat }}\right)[33,291,293]$. As shown in Figures 24 and 25, bio-oxygenates are reformed at comparable rates [297,298], while quantum efficiencies can be raised significantly (to $\Phi \geq 30 \%$ ) due to the superior illumination geometry available in an optical fibre honeycomb reactor [297].

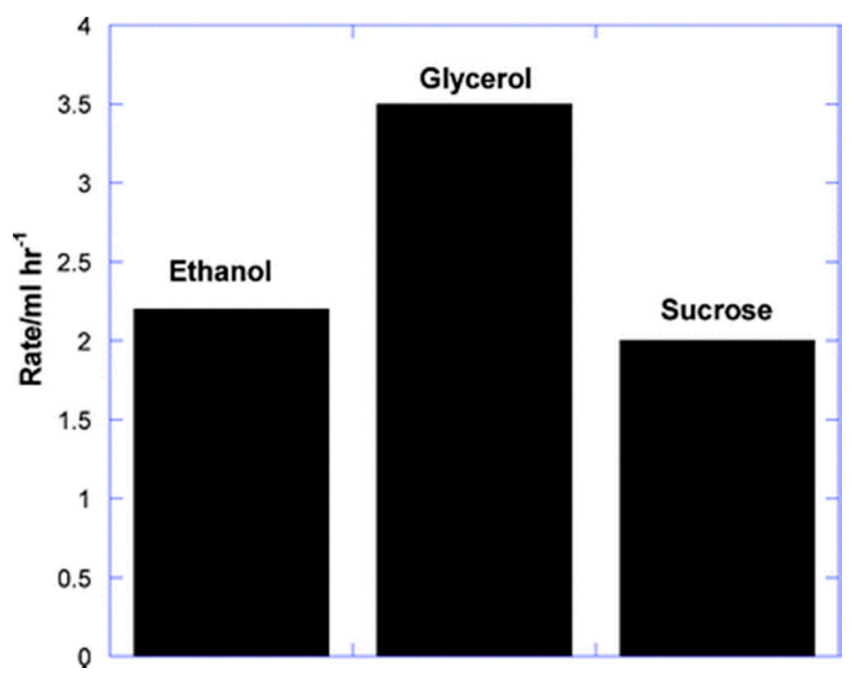

Figure 24. Rate of $\mathrm{H}_{2}$ evolution by photo reforming of 3 important bio-oxygenates ( $1 \%$ in $\mathrm{H}_{2} \mathrm{O}$ ) over 0.3 wt \% $\mathrm{Pd} / \mathrm{TiO}_{2}(\mathrm{P} 25)$ (reproduced from [298] with permission of RSC).

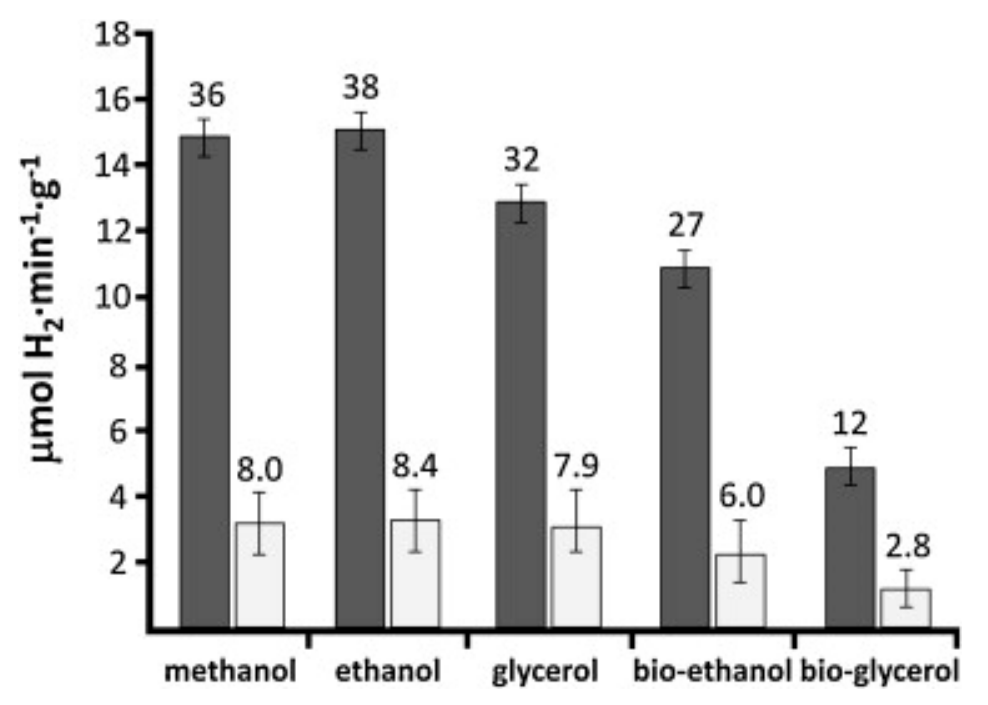

Figure 25. $\mathrm{H}_{2}$ evolution rates and quantum efficiencies of bio-alcohols $\left(1: 1 \mathrm{H}_{2} \mathrm{O}\right)$ in a catalytic wall reactor (dark) or a slurry reactor (light) over $1 \mathrm{wt} \% \mathrm{Au} / \mathrm{TiO}_{2}$. (reproduced from [297] with permission of Elsevier). 
Early investigations of photo-reforming over visible-active catalysts include SPR metals on $\mathrm{TiO}_{2}$ [304], $\mathrm{Cd}_{1-x} \mathrm{Zn}_{\times} \mathrm{S} / \mathrm{ZnO}$ [305], $\mathrm{CdS} / \mathrm{TiO}_{2}$ [306], $\varepsilon-\mathrm{Fe}_{2} \mathrm{O}_{3}$ [307,308], and a potentially self-degrading glucose- $\mathrm{TiO}_{2}$ charge transfer complex [309]. However, only the chalcogenide-based system gave a respectable quantum efficiency, $\Phi>420 \mathrm{~nm}=9.6 \%$ [305]. Glycerol photoreforming over earth-abundant co-catalysts $\mathrm{CuO}_{x} / \mathrm{TiO}_{2}[310,311]$ and $\mathrm{NiO}_{x} / \mathrm{TiO}_{2}[312]$ has also been reported.

\section{Photoreduction of Carbon Dioxide: Artificial Photosynthesis}

As mentioned in the Introduction, a valuable (solar) energy-storing artificial photosynthetic process which couples two stages in the energy scheme is methanol synthesis from carbon dioxide and water:

$$
\mathrm{CO}_{2}+2 \mathrm{H}_{2} \mathrm{O} \leftrightarrow \mathrm{CH}_{3} \mathrm{OH}+1.5 \mathrm{O}_{2}
$$

although ethanol synthesis:

$$
2 \mathrm{CO}_{2}+3 \mathrm{H}_{2} \mathrm{O} \leftrightarrow \mathrm{C}_{2} \mathrm{H}_{5} \mathrm{OH}+3 \mathrm{O}_{2}
$$

would be even better due to its higher energy density, lower toxicity and volatility. However, Equation (24) is probably unrealistic due to its mechanistic complexity and associated selectivity issues, at least as reported in $\mathrm{CO}_{2}$ hydrogenation [26,27]. Methanol synthesis per se (Equation (23)) is already complex as it subsumes the water splitting process (see Equation (6)) but is $50 \%$ more demanding energetically $(\Delta \mathrm{H}=+727 \mathrm{~kJ} / \mathrm{mol})$ due to the evolution of proportionately more $\mathrm{O}_{2}$, as shown by the relevant half-cell reactions:

$$
\begin{gathered}
\mathrm{CO}_{2}+6 \mathrm{H}^{+}+6 \mathrm{e}^{-} \rightarrow \mathrm{CH}_{3} \mathrm{OH}+\mathrm{H}_{2} \mathrm{O}\left[\mathrm{E}^{\circ}=-0.32 \mathrm{~V}\right] \\
3 \mathrm{H}_{2} \mathrm{O} \rightarrow 1.5 \mathrm{O}_{2}+6 \mathrm{H}^{+}+6 \mathrm{e}^{-}\left[\mathrm{E}^{\circ}=+1.23 \mathrm{~V}\right]
\end{gathered}
$$

and comparison of Equations (6) and (26). While this $6 \mathrm{e}^{-}$process can be driven by near-IR photons, it is mechanistically more complex than water splitting as two elementary steps (proton reduction and $\mathrm{H}$ atom coupling) at the photocathode are replaced by activation of a stable gas molecule of low aqueous solubility, its multi-step reductive de-oxygenation, and progressive hydrogenation (Equation (25)). It perhaps comes as no surprise that carbon-based solar-to-fuel conversion efficiencies lag far behind those of water splitting at $<1 \%$, with turnover rates $\left(10-100 \mu \mathrm{mol} / \mathrm{h} / \mathrm{g}_{\text {cat }}\right)$ over pristine semiconductors still too low for technical exploitation $[43,45,79]$. Achieving high selectivity to methanol is also a challenge insofar as $\mathrm{CH}_{4}$ is preferentially obtained over hydrated anatase $\mathrm{TiO}_{2}[313,314]$, unless the surface $\mathrm{Ti}^{4+}$ (electron trap) centre is highly-dispersed or isolated [315].

Nonetheless, as shown in Figure 26, there is general agreement that the photocatalyst plays an indispensible role in activating $\mathrm{CO}_{2}$ (the probable rate-determining step) by electron transfer and stabilizing the highly energetic $\mathrm{CO}_{2}{ }^{-}$radical ion in coordinated form(s) [43,316,317]. Possible sequences of proton-coupled electron transfer in $\mathrm{CO}_{2}$ conversion to formic acid are shown in Figure 27. DFT-modeled energy barriers favor the green route via bidentate coordination mode B1 $(0.87 \mathrm{eV})$ and the red route via the linear monodentate mode $\mathrm{A} 1(0.82 \mathrm{eV})$ although this is less likely as it requires a simultaneous two $\mathrm{e}^{-}$transfer. Routes (black) via carbonato-type complexes A2 and B2 proceeding through carboxyl $(\mathrm{COOH})$ intermediate have much higher energy barriers, $2.25 \mathrm{eV}$ and $1.73 \mathrm{eV}$, respectively. 


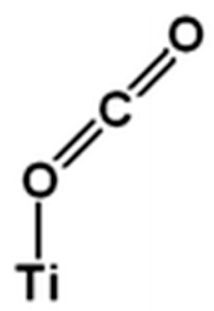

A1

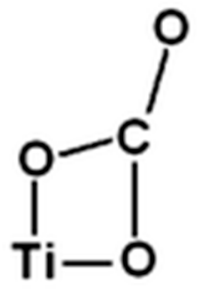

A2

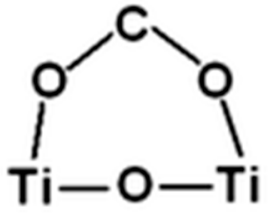

B1

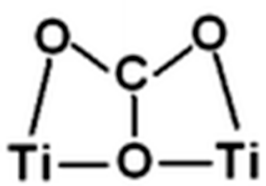

B2

Figure 26. DFT-modeled states of neutral/anionic $\mathrm{CO}_{2}$ adsorbed on $\mathrm{TiO}_{2}$ anatase (101) (reproduced from [316] with permission of the Royal Society of Chemistry).

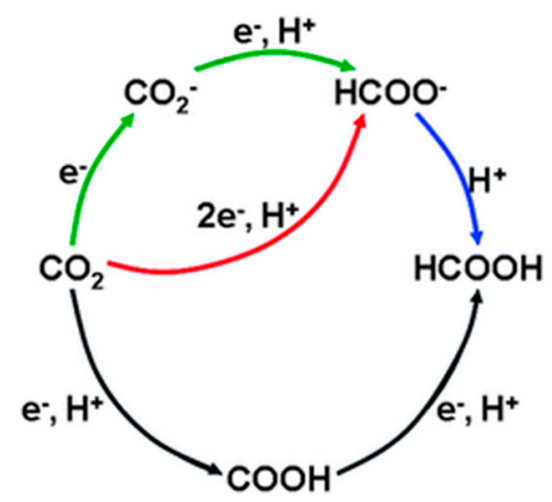

Figure 27. Pathways of $2 \mathrm{e}^{-} / 2 \mathrm{H}^{+}$photoreduction of $\mathrm{CO}_{2}$ to formic acid. DFT energy barriers $(<1 \mathrm{eV})$ favour the green route (via B1) and the red route (via A1) (reproduced from [316] with permission of the Royal Society of Chemistry).

It is evident from the literature [24,43,317] that earth-abundant $\mathrm{Cu}$ is a ubiquitous co-catalyst in $\mathrm{CO}_{2}$ reduction, yielding mainly methanol in gas-solid photocatalysis or methane by electrocatalysis. This selectivity effect has been rationalized [318] as due to reaction of the surface-bound methoxy $\left(\mathrm{CH}_{3} \mathrm{O}-\mathrm{Cu}\right)$ intermediate either with a co-adsorbed $\mathrm{H}$ atom (favouring $\mathrm{CH}_{3} \mathrm{OH}$ by a lateral surface mechanism) as in the industrial synthesis [319], or with a proton from aqueous solution (favouring $\mathrm{CH}_{4}$ via attack on the protruding $\mathrm{CH}_{3}$ moiety). The prevalence of $\mathrm{Cu}$ (or $\mathrm{CuO}_{x}$ ) in composite photocatalysts [41,43-45,320-323] and electrodes [319,324-326] suggests that the dark mechanism "post-formate" is still operative but in which water photo-oxidation provides the electron/proton pairs in Equation (25), i.e., the half-cell equivalents of $\mathrm{H}$ atoms from $\mathrm{H}_{2}$ dissociation. If this is the case, the thermal mechanism remains important [19] and an approach toward industrial synthesis conditions is worthy of study, e.g., mild heating/pressurization of $\mathrm{CO}_{2} / \mathrm{H}_{2} \mathrm{O}$ vapour under illumination. Publications have recently proliferated on the role of nanocarbons and graphenes as cocatalysts in composite photocatalysts [327-329], including photo- [40,330-332] and electro-reduction of $\mathrm{CO}_{2}$ [333]. This is linked mainly to their effectiveness in promoting charge separation [327-329,334], although there are tentative claims for visible sensitization, possibly due to adventitious C doping [40,327-329]. There is also growing evidence that graphene oxide can act as a photocatalyst per se [335] although $\mathrm{CH}_{3} \mathrm{OH}$ synthesis activity is improved by addition of $\mathrm{Cu}$ [336] and/or molecular sensitizers [337]. Otherwise, visible response has been conferred to $\mathrm{TiO}_{2}$ nanocomposites by incorporating $\mathrm{CdS} / \mathrm{Bi}_{2} \mathrm{~S}_{3}$ [338], CdSe quantum dots [339], or plasmonic metal deposits [340]. While promising advances have been made in "self-biasing" 
particulates, the tendency of methanol to act as an efficient hole scavenger may ultimately militate against a gas-phase photocatalytic approach in favour of a PEC (membrane-separated photo-electrode) arrangement, as shown in Figure 28. This is despite the known limitations of the latter, viz., $\mathrm{CO}_{2}$ solubility/mass transfer issues in the liquid phase [79], and a higher probability of obtaining $\mathrm{CH}_{4}$ on a photoelectrode [318,326].

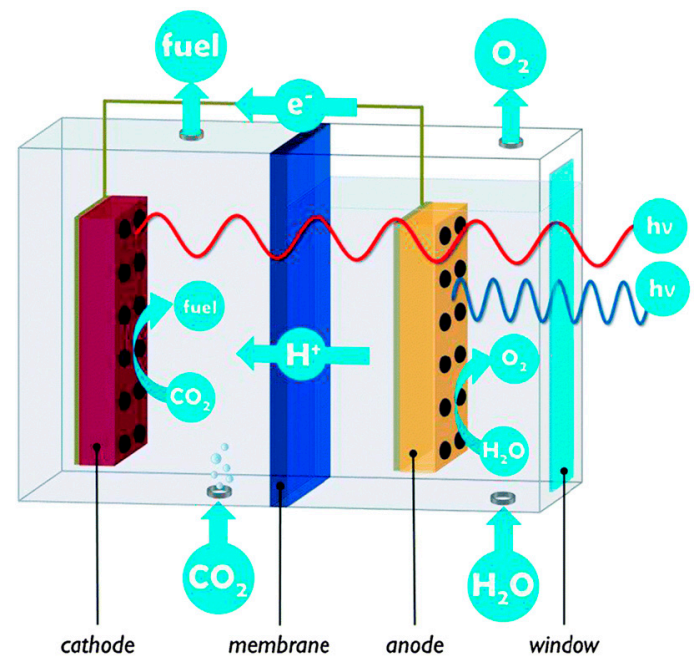

Figure 28. Liquid-phase 2-compartment $\mathrm{PEC}$ cell for $\mathrm{CO}_{2}$ photo-reduction. (reproduced from [79] with permission of the Royal Society of Chemistry).

As a potential solution, and borrowing concepts from PEM fuel cell technology, gas-phase electrocatalytic studies using a gas diffusion membrane electrode (GDM) configuration have given improved $\mathrm{CO}_{2}$ conversion rates (Faradaic efficiencies) and a selectivity shift towards oxygenates over carbon nanotube-supported Pt and Fe [333,341,342], as shown in Figure 29. The beneficial effect of mild heating is also evident.

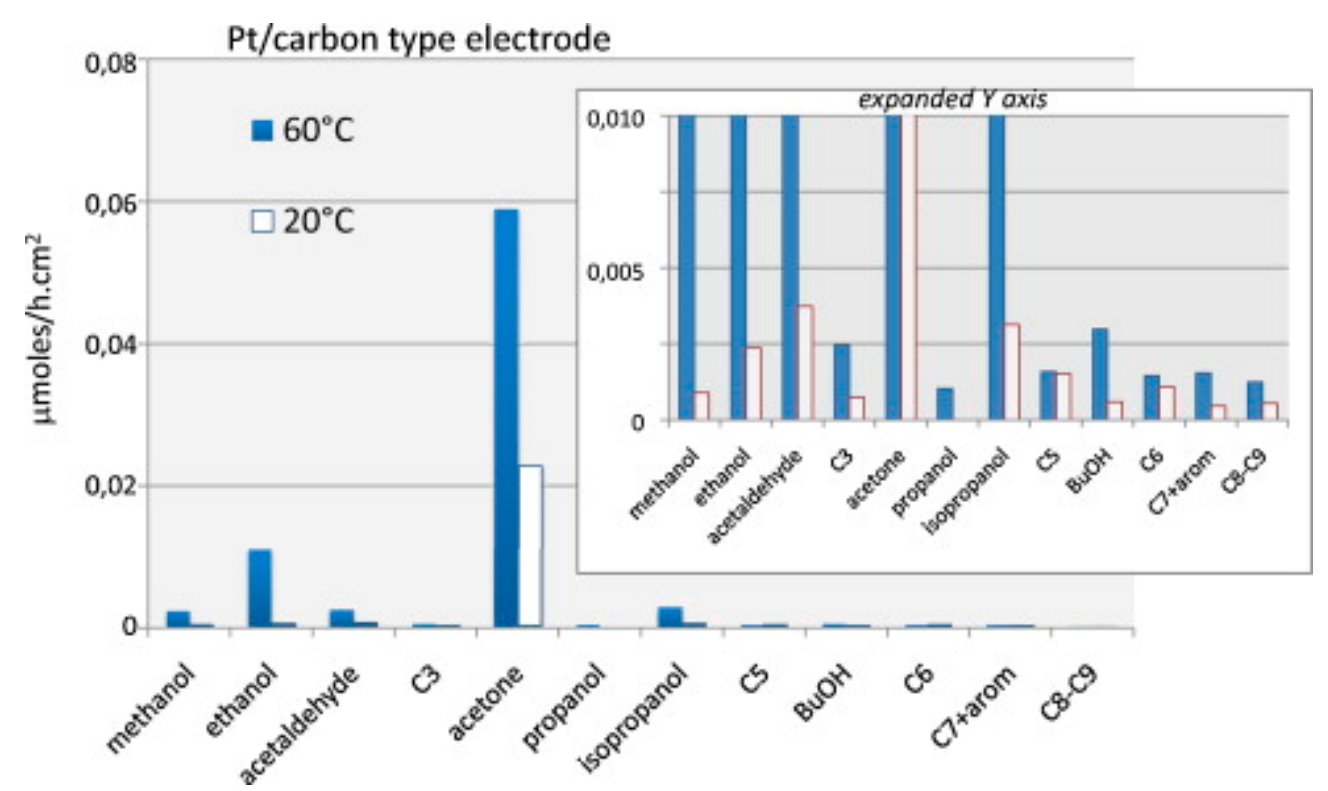

Figure 29. Temperature effect in gas phase $\mathrm{CO}_{2}$ electro-reduction on $10 \% \mathrm{Pt} / \mathrm{Carbon} /$ Nafion117 GDM electrode (reproduced from [333] with permission of Elsevier). 
Regarding the dark mechanism in industrial methanol synthesis (from $\mathrm{CO}_{2} / \mathrm{CO}$ ) over supported $\mathrm{Cu}$, a recent microkinetic/DFT modeling paper [343] casts doubt on the formate (HCOO) $\rightarrow$ dioxomethylene $\left(\mathrm{H}_{2} \mathrm{COO}\right)$ route in favour of carboxyl $(\mathrm{COOH}) \rightarrow$ formic acid $[\mathrm{HC}(\mathrm{OH}) \mathrm{O}] \rightarrow$ hydroxymethoxy $\left[\mathrm{H}_{2} \mathrm{C}(\mathrm{OH}) \mathrm{O}\right]$ $\rightarrow$ formaldehyde (hydroxyl) $\left[\mathrm{CH}_{2} \mathrm{O}(\mathrm{OH})\right] \rightarrow$ methoxy $\left(\mathrm{CH}_{3} \mathrm{O}\right)$. The hydroxymethoxy species is rightly considered the key intermediate but its identity as the conjugate base of methanediol or methylene glycol (formaldehyde hydrate) has seemingly not been recognized [343,344]. This species is implicated in the Cannizzaro disproportionation involving a hydride or proton-coupled $2 \mathrm{e}^{-}$transfer reaction [345-348]:

$$
2 \mathrm{H}_{2} \mathrm{C}(\mathrm{OH}) \mathrm{O} \rightarrow \mathrm{CH}_{3} \mathrm{O}+\mathrm{HCOO}+\mathrm{H}_{2} \mathrm{O}
$$

thereby providing a simpler (direct) path to methoxy.

\section{Summary and Outlook}

From this brief overview of a burgeoning field of research over the last two to three decades, it is somewhat puzzling and disappointing to admit that a "solar fuels" industry is still no more than a futuristic concept [349] with no clear indication as to when to expect its realization [58], or at least the emergence of (pre-commercial) demonstration systems. A recent review of the proliferating patent literature reveals that they are almost exclusively based on incremental advances at the fundamental level, many being filed by academic scientists [42]. However, looked at sub specie aeternatitis, one must recognize the enormity of the challenge facing Mankind, viz., a paradigm shift towards a sustainable global economy based on an entirely new foundation, or what could be termed "renewable petrochemistry" [350]. The expanding role of industrial catalysis in such a future will require a thorough evaluation of scalability issues, not least in global elemental resources [68] for a sector established largely on the exploitation of rare metals. Photocatalysis and the maturation of commercial photoreactor design [351] in environmental detoxification is certainly gaining an industrial foothold [13], but this reviewer has only come across one pertinent reference to $\mathrm{H}_{2}$ photogeneration on a pilot scale, and even this did not involve water splitting $\left(\mathrm{O}_{2}\right.$ co-generation) but photoreforming of aqueous organic contaminants over $\mathrm{Pt} / \mathrm{N}-\mathrm{TiO}_{2}$ and $\mathrm{Pt} / \mathrm{CdS} / \mathrm{ZnS}$ [352]. Otherwise, nanoparticulate suspensions have demonstrated very low efficiencies to date $(\leq 1 \%)$ and offer merely simplicity and convenience in operation. Disadvantages include unwieldy reactor size/catalyst charge and an associated explosion hazard in the absence of a $\mathrm{H}_{2} / \mathrm{O}_{2}$ separation stage. In contrast, implementation of a PEC-membrane-integrated tandem system that yields pure $\mathrm{H}_{2}$ at STH efficiencies already exceeding $10 \%$ in the laboratory (mandated to meet the US DOE cost target of USD 2.00-4.00 per $\mathrm{kg} \mathrm{H}_{2}$ [353]), is hampered by complexities associated with device design and scale-up, especially geometric factors and their role in loss (optical and overvoltage) minimization [354-356]. Indeed, the question as to whether an integrated (PV-PEC) design will ultimately outperform coupled PV-electrolyzers (with independently optimized components), or if their co-development has advantages [230,233,234,357], is still open to debate $[58,59,226,358,359]$. Certainly the former raises more materials compatibility issues since electrolyzers work best in acid or alkaline environments. According to McKone et al. [58], priority needs in fundamental work include: (a) Higher efficiency electrolysis in buffered pH-neutral electrolyte (for greater durability of earth-abundant absorbers and catalysts); (b) More conductive anion (alkaline) exchange membranes (thinner separators lead to higher efficiency electrolysis and faster $\mathrm{pH}$ 
equilibration); (c) More earth-abundant OER catalysts stable in acidic media (a major expansion in PEM-based devices will otherwise be limited by their present dependence on precious metal catalysts); (d) Optical transparency in lower mass-specific activity co-catalysts (minimal parasitic light absorption); and (e) A wider range of stable (acid/alkali -resistant) visible light absorbers and transparent (ultra-thin protective) layers for $\mathrm{Si}$.

Two excellent articles have appeared recently that address the technoeconomic feasibility of centralized facilities for solar hydrogen [60] and the more complex case of solar methanol, which includes the problem of $\mathrm{CO}_{2}$ sourcing [231]. Pinaud et al. [60] considered four types of reactor systems of increasing complexity designed to generate 1 ton per day of pure $\mathrm{H}_{2}$ at 20 bar from $0.1 \mathrm{M} \mathrm{KOH}$ solution/electrolyte. Type 1 was an array of 18 shallow plastic "baggies" $(323 \times 12 \times 0.1 \mathrm{~m})$ housing a single-bed photocatalyst particle suspension working at an assumed STH efficiency ( $\eta$ ) of $10 \%$ (theoretical $\eta_{\max } \approx 23 \%$ ). Type 2 was similar but had two (types of photocatalyst) beds for separate generation of $\mathrm{H}_{2}$ and $\mathrm{O}_{2}$ coupled by redox mediators (Z-scheme) $-\eta=5 \%\left(\eta_{\max } \approx 15 \%\right)$. Type 3 was a fixed panel array of $\sim 27,000$ monolithic tandem absorber PEC cells $-\eta=10 \%\left(\eta_{\max } \approx 30 \%\right)$, while Type 4 was similar but with a drastically reduced number of cells $(\sim 2,000$, generating equivalent power $)$ due to coupling with a tracking concentrator $(\times 10)$ assembly $-\eta=15 \%$. The estimated cost of $\mathrm{H}_{2}(\mathrm{per} \mathrm{kg})$ for the four cases was $\$ 1.60, \$ 3.20, \$ 10.40$, and $\$ 4.00$, respectively. These are encouraging figures but it should be recognized that the efficiencies assumed for the particulate systems were "target" values several times higher than the current state-of-the-art. Clearly, the most promising and realistic system for early demonstration would be Type 4. However, the inclusion of low-power concentrators adds further complexity [360] and raises the question as to how PEC-based systems actually respond to light intensification and to what extent it is influenced by device configuration. While it is well-known that efficiencies in PV arrays are maintained (or even improved) by concentration of sunlight [361,362], the progressive drop in photochemical quantum yields with increasing incident power in suspended particulate systems is notorious [363], explaining the virtual absence of concentrating optics in advanced oxidation photoreactors, excepting perhaps the compound parabolic reflector for improved collection of diffuse sunlight [351]. The problem is generally attributed to kinetic limitations in surface redox processes and/or $\mathrm{O}_{2}$ supply due to low aqueous solubility. Some of these "chemical" constraints are shared by PEC cells, such that a strong case can be made for a systematic evaluation of the sensitivity of water splitting efficiency to solar light concentration. The only positive evidence in the open literature is the NREL claim of a record-breaking 12\% efficiency (in 1998) using a prototype hybrid PV/PEC system comprising a $\mathrm{GaInP}_{2}$ photocathode voltage-biased by an underlying GaAs (PV) absorber under 11 Suns illumination [364].

Herron et al. [231] have taken a broader approach in designing a "transitional" solar refinery that produces $\mathrm{H}_{2}$ as an intermediate in the generation of liquid fuels but with sub-systems still dependent to some degree on fossil fuel energy input, as represented schematically in Figure 30. First, a feasibility study was made by assessing the energy balance for the indirect route based on existing (sub-system) efficiencies. The CAMERE process [365] was selected and modeled, viz., methanol synthesis (at $1 \mathrm{~kg} / \mathrm{s} \equiv 22.7 \mathrm{MWhнv}$ ) from $\mathrm{CO}_{2}$ (captured from a fossil fuel power station) with $\mathrm{H}_{2}$ (produced increasingly from solar energy), and defining the solar or primary "energy incorporation efficiency" (EIE) as being positive (viable) only when the methanol energy content exceeded the sum of all fossil energy inputs. This rather severe criterion was not satisfied even when all the $\mathrm{H}_{2}$ was derived from solar 
energy. Thus, there is a need for diversification and greater implementation of solar technologies in early demonstration systems. A good candidate (energy-intensive) process for fossil fuel substitution is solar heat-driven $\mathrm{CO}_{2}$ recovery in amine scrubbers and, ultimately, atmospheric trapping devices [20,21].

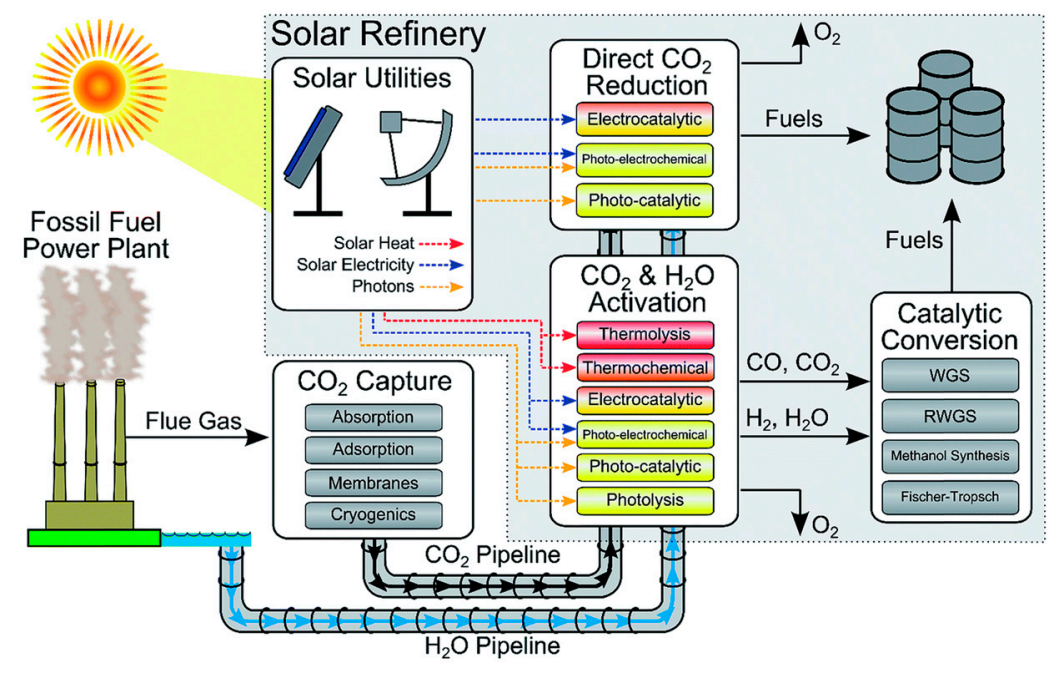

Figure 30. Scheme of a solar refinery based on $\mathrm{CO}_{2}$ reduction to methanol indirectly by renewable $\mathrm{H}_{2}$ (ex solar photon- or heat-driven electrolysis) or directly ("one pot") with $\mathrm{H}_{2} \mathrm{O}$ using solar-electricity (PEC) or solar photons (photocatalysis) (reproduced from [231] with permission of the Royal Society of Chemistry).

A case study estimating the threshold $\mathrm{CO}_{2}$ single-pass conversion for positive EIE based on a direct (photocatalytic) route was also made, assuming a reaction selectivity of $40 \%$ as below:

$$
\mathrm{CO}_{2}+2 \mathrm{H}_{2} \mathrm{O} \rightarrow 0.6 \mathrm{CH}_{4}+0.4 \mathrm{CH}_{3} \mathrm{OH}+1.8 \mathrm{O}_{2}
$$

and a catalyst mass-specific rate of $\sim 1 \mu \mathrm{mol} / \mathrm{g}_{\mathrm{cat}} / \mathrm{h}\left(\Phi_{\mathrm{uv}}=0.28 \%\right.$ over Ti-containing porous $\left.\mathrm{SiO}_{2}[366]\right)$. As shown in Figure 31, it is primarily the $\mathrm{CO}_{2}$ capture stage (from dilute flue gas) that impedes the energy efficiency break-even point $(\mathrm{EIE}=0)$, such that present costs of around $5.5 \mathrm{MJ} / \mathrm{kgCO} 2$ must be further reduced. If the enthalpy from burning the renewable $\mathrm{CH}_{4}$ co-product is valorized, positive energy incorporation is feasible below 50\% conversion. Better still, if a more selective catalyst can be developed, it would simplify the process and have a dramatic effect on minimum one-pass conversion (EIE $>0$ ), as shown in Figure 32. However, by the authors' own admission, this case is quite impractical due to the low activity of the photocatalyst, roughly 3 orders of magnitude below that required as discussed in Sections 4 and 5 . Even at $1 \mathrm{mmol} / \mathrm{g}_{\text {cat }} / \mathrm{h}$, for an overall production rate of $1 \mathrm{~kg} / \mathrm{s}$, it would need $100 \mathrm{metric}$ tons of catalyst and a reactor volume of $100 \mathrm{~m}^{3}$ severely constrained in one dimension by optical factors.

In closing, the author feels obliged to point out that the earlier review [19] was written on the premise that future market penetration by the renewable energy sector would be substantial and already impacting (slowing the rise of, if not stabilizing) global $\mathrm{CO}_{2}$ levels in the atmosphere. Unfortunately, governments have not provided sufficient incentives or regulatory measures to curb our dependence on fossil fuels and the oil industry has conducted very much a "business-as-usual" policy. In the last 20 years, the rate of emissions has increased by $50 \%$ and a cumulative level of $400 \mathrm{ppm} \mathrm{CO}_{2}$ has been reached, i.e., $50 \mathrm{ppm}$ in excess of the threshold considered necessary to avoid a mean global temperature rise of more than $2{ }^{\circ} \mathrm{C}$ with probable catastrophic effects. While the penetration of $\mathrm{CO}_{2}$-neutral energy systems will 
help to ease the burden on natural sinks for $\mathrm{CO}_{2}$, it now appears essential to augment these with artificial (man-made) disposal methods. The author's directions in research have broadened accordingly in recent years, favouring mineralization as the only technology that will guarantee $\mathrm{CO}_{2}$ sequestration on the requisite (geological) time-scale [367-371].

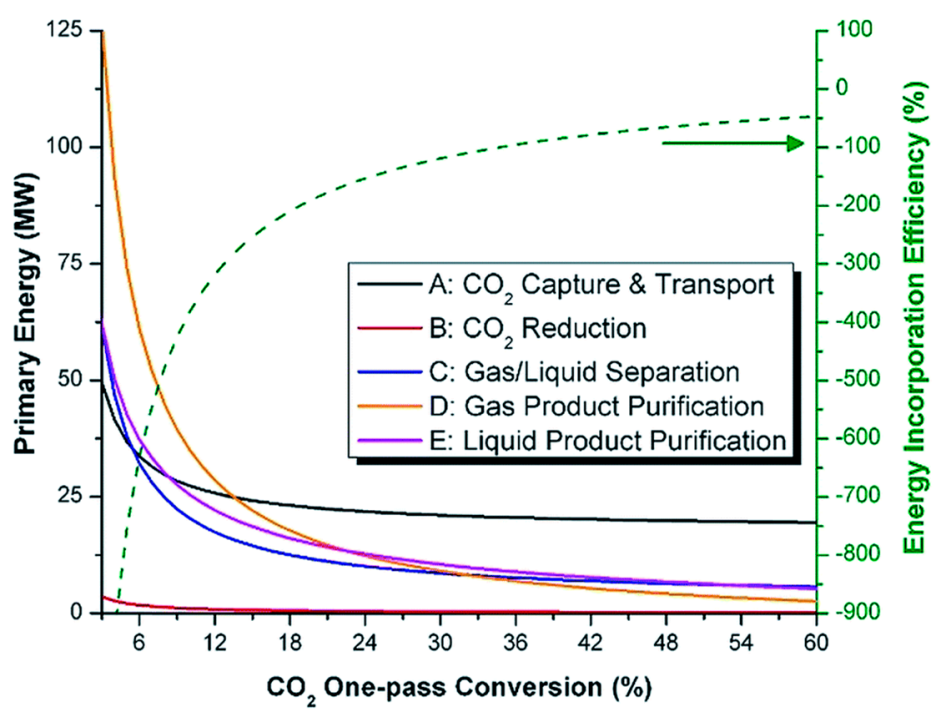

Figure 31. Dominance of $\mathrm{CO}_{2}$ capture stage on primary energy costs in photocatalytic $\mathrm{CH}_{3} \mathrm{OH}$ synthesis from $\mathrm{CO}_{2} / \mathrm{H}_{2} \mathrm{O}$ (reproduced from [232] with permission of the Royal Society of Chemistry).

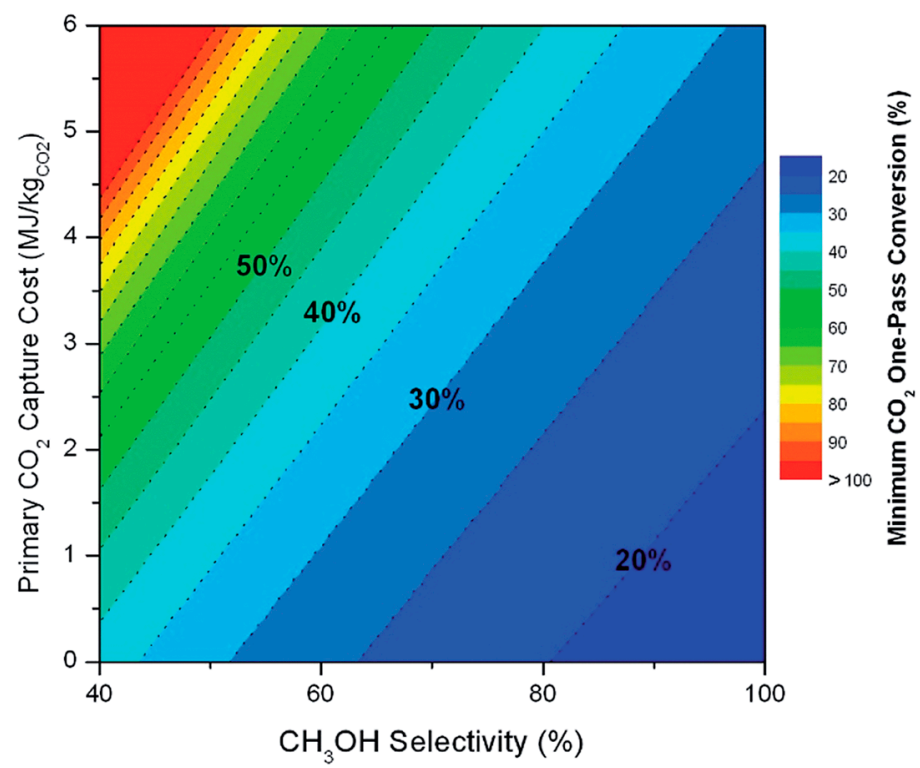

Figure 32. Effect of photocatalyst selectivity and $\mathrm{CO}_{2}$ capture cost on minimum one-pass conversion for positive energy incorporation efficiency (EIE $>0$ ) (reproduced from [231] with permission of the Royal Society of Chemistry).

\section{Acknowledgments}

The author is grateful to Eric Claude, Innovation Director at Axane (Air Liquide, Grenoble, France), for valuable advice on the hydrogen peroxide fuel cell. 


\section{Conflicts of Interest}

The author declares no conflict of interest.

\section{References}

1. Smalley, R.E. Future Global Energy Prosperity: The Terawatt Challenge. MRS Bull. 2005, 30, 412.

2. Bell, A.T. The Impact of Nanoscience on Heterogeneous Catalysis. Science 2003, 299, 1688-1691.

3. Rolison, D.R. Catalytic Nanoarchitectures-The Importance of Nothing and the Unimportance of Periodicity. Science 2003, 299, 1698-1701.

4. Nørskov, J.K.; Bligaard, T.; Rossmeisl, J.; Christensen, C.H. Towards the Computational Design of Solid Catalysts. Nat. Chem. 2009, 1, 37-46.

5. Semagina, N.; Kiwi-Minsker, L. Recent Advances in the liquid-phase synthesis of metal nanostructures with controlled shape and size for catalysis. Catal. Rev. Sci. Eng. 2009, 51, 147-217.

6. Cuenya, B.R. Synthesis and Catalytic Properties of Metal Nanoparticles: Size, Shape, Support, Composition, and Oxidation State Effects. Thin Solid Films 2010, 518, 3127-3150.

7. Yuan, Y.; Yan, N.; Dyson, P.J. Advances in the Rational Design of Rhodium Nanoparticle Catalysts: Control via Manipulation of the Nanoparticle Core and Stabilizer. ACS Catal. 2012, 2, 1057-1069.

8. Guo, Z.; Liu, B.; Zhang, Q.H.; Deng, W.P.; Wang, Y.; Yang, Y.H. Recent Advances in Heterogeneous Selective Oxidation Catalysis for Sustainable Chemistry. Chem. Soc. Rev. 2014, 43, 3480-3524.

9. Schlögl, R.; Abd Hamid, S.B. Nanocatalysis: Mature Science Revisited or Something Really New? Angew. Chem. Int. Ed. 2004, 43, 1628-1637.

10. Chen, X.; Li, C.; Grätzel, M.; Kostecki, R.; Mao, S.S. Nanomaterials for Renewable Energy Production and Storage. Chem. Soc. Rev. 2012, 41, 7909-7937.

11. Thomas, J.M. Heterogeneous Catalysis and the Challenges of Powering the Planet, Securing Chemicals for Civilised Life, and Clean Efficient Utilization of Renewable Feedstocks. ChemSusChem 2014, 7, 1801-1832.

12. Kondratenko, E.V.; Mul, G.; Baltrusaitis, J.; Larrazabal, G.O.; Perez-Ramirez, J. Status and Perspectives of $\mathrm{CO}_{2}$ Conversion into Fuels and Chemicals by Catalytic, Photocatalytic and Electrocatalytic Processes. Energy Environ. Sci. 2013, 6, 3112-3135.

13. Lu, M. Photocatalysis and Water Purification: From Fundamentals to Recent Applications; Pichat, P., Ed.; Wiley-VCH Verlag: Weinheim, Germany, 2013.

14. Ohtani, B. Photocatalysis A to Z-What We Know and What We Do Not Know in a Scientific Sense. J. Photochem. Photobiol. C Photochem. Rev. 2010, 11, 157-178.

15. Kalyanasundaram, K.; Grätzel, M. Artificial Photosynthesis: Biomimetic Approaches to Solar Energy Conversion and Storage. Curr. Opin. Biotechnol. 2010, 21, 298-310.

16. Wang, Y.; Chen, K.S.; Mishler, J.; Cho, S.C.; Adroher, X.C. A review of polymer electrolyte membrane fuel cells: Technology, applications, and needs on fundamental research. Appl. Energy 2011, 88, 981-1007.

17. Durbin, D.J.; Malardier-Jugroot, C. Review of Hydrogen Storage Techniques for On-Board Vehicle Applications. Int. J. Hydrogen Energy 2013, 38, 14595-14617. 
18. Muradov, N.Z.; Veziroglu, T.N. "Green" Path from Fossil-Based to Hydrogen Economy: An Overview of Carbon-Neutral Technologies. Int. J. Hydrogen Energy 2008, 33, 6804-6839.

19. Highfield, J.G. The Central Role of Catalysis in a Future Energy Cycle based on Renewable Hydrogen and Carbon Dioxide as Reactive Liquefier. Trends Phys. Chem. 1995, 5, 91-156.

20. Goeppert, A.; Czaun, M.; Prakash, G.K.S.; Olah, G.A. Air as the Renewable Carbon Source of the Future: An Overview of $\mathrm{CO}_{2}$ Capture from the Atmosphere. Energy Environ. Sci. 2012, 5, 7833-7853.

21. Lackner, K.S. The Thermodynamics of Direct Air Capture of Carbon Dioxide. Energy 2013, 50, 38-46.

22. Alonso, D.M.; Bond, J.Q.; Dumesic, J.A. Catalytic Conversion of Biomass to Biofuels. Green Chem. 2010, 12, 1493-1513.

23. Olah, G.A.; Goeppert, A.; Prakash, G.K.S. Beyond Oil and Gas: The Methanol Economy, 1st ed.; Wiley-VCH: Weinheim, Germany, 2006.

24. Goeppert, A.; Czaun, M.; Jones, J.P.; Prakash, G.K.S.; Olah, G.A. Recycling of Carbon Dioxide to Methanol and Derived Products-Closing the Loop. Chem. Soc. Rev. 2014, 43, 7995-8048.

25. Galindo Cifre, P.; Badr, O. Renewable Hydrogen Utilisation for the Production of Methanol. Energy Convers. Manag. 2007, 48, 519-527.

26. Wang, W.; Wang, S.; Ma, X.; Gong, J. Recent Advances in Catalytic Hydrogenation of Carbon Dioxide. Chem. Soc. Rev. 2011, 40, 3703-3727.

27. Velu, S.; Gangwal, S.K. A Review of Recent Literature to Search for an Efficient Catalytic Process for the Conversion of Syngas to Ethanol. Energy Fuels 2008, 22, 814-839.

28. Palo, D.R.; Dagle, R.A.; Holladay, J.D. Methanol Steam Reforming for Hydrogen Production. Chem. Rev. 2007, 107, 3992-4021.

29. Huang, L.; Choong, C.; Chen, L.W.; Wang, Z.; Zhong, Z.Y.; Campos-Cuerva, C.; Lin, J.Y. Monometallic Carbonyl-Derived $\mathrm{CeO}_{2}$-Supported $\mathrm{Rh}$ and $\mathrm{Co}$ Bicomponent Catalysts for CO-Free, High-Yield $\mathrm{H}_{2}$ Generation from Low-Temperature Ethanol Steam-Reforming. ChemCatChem 2013, 5, 220-234.

30. Mattos, L.V.; Jacobs, G.; Davis, B.H.; Noronha, F.B. Production of Hydrogen from Ethanol: Review of Reaction Mechanism and Catalyst Deactivation. Chem. Rev. 2012, 112, 4094-4123.

31. De la Piscina, P.R.; Homs, N. The Use of Biofuels to Produce Hydrogen (Reformation Processes). Chem. Soc. Rev. 2008, 37, 2459-2467.

32. De Rogatis, L.; Fornasiero, P.; Catalyst Design for Reforming of Oxygenates. In Catalysis for Sustainable Energy Production; Barbaro, P., Bianchini, C., Eds.; Wiley-VCH Verlag GmbH: Weinheim, Germany, 2009; Chapter 6, pp. 173-232.

33. Tran, N.H.; Kannangara, G.S.K. Conversion of Glycerol to Hydrogen Rich Gas. Chem. Soc. Rev. 2013, 42, 9454-9479.

34. Chheda, J.N.; Huber, G.W.; Dumesic, J.A. Liquid-Phase Catalytic Processing of Biomass-Derived Oxygenated Hydrocarbons to Fuels and Chemicals. Angew. Chem. Int. Ed. 2007, 46, 7164-7183.

35. Bowker, M. Photocatalytic Hydrogen Production and Oxygenate Photoreforming. Catal. Lett. 2012, 142, 923-929.

36. Jiang, Z.; Xiao, T.; Kuznetsov, V.L.; Edwards, P.P. Turning Carbon Dioxide into Fuel. Philos. Trans. R. Soc. A 2010, 368, 3343-3364. 
37. Li, C.; Domen, K.; Hutchings, G.J. Special Issue on Photocatalysis and Photoelectrolysis. J. Catal. 2014, 310, 1-108.

38. Dasgupta, S.; Brunschwig, B.S.; Winkler, J.R.; Gray, H.B. Solar Fuels Editorial. Chem. Soc. Rev. 2013, 42, 2205-2472.

39. Qu, Y.; Duan, X. Progress, Challenge and Perspective of Heterogeneous Photocatalysts. Chem. Soc. Rev. 2013, 42, 2568-2580.

40. Sun, H.; Wang, S. Research Advances in the Synthesis of Nanocarbon-based Photocatalysts and Their Applications for Photocatalytic Conversion of Carbon Dioxide to Hydrocarbon Fuels. Energy Fuels 2014, 28, 22-36.

41. Li, K.; An, X.; Park, K.H.; Khraisheh, M.; Tang, J. A Critical Review of $\mathrm{CO}_{2}$ Photoconversion: Catalysts and Reactors. Catal. Today 2014, 224, 3-12.

42. Protti, S.; Albini, A.; Serpone, N. Photocatalytic Generation of Solar Fuels from the Reduction of $\mathrm{H}_{2} \mathrm{O}$ and $\mathrm{CO}_{2}$ : A Look at the Patent Literature. Phys. Chem. Chem. Phys. 2014, 16, 19790-19827.

43. Habisreutinger, S.N.; Schmidt-Mende, L.; Stolarczyk, J.K. Photocatalytic Reduction of $\mathrm{CO}_{2}$ on $\mathrm{TiO}_{2}$ and Other Semiconductors. Angew. Chem. Int. Ed. 2013, 52, 7372-7408.

44. Izumi, Y. Recent Advances in the Photocatalytic Conversion of Carbon Dioxide to Fuels with Water and/or Hydrogen Using Solar Energy and Beyond. Coord. Chem. Rev. 2013, 257, 171-186.

45. Dhakshinamoorthy, A.; Navalon, S.; Corma, A.; Garcia, H. Photocatalytic $\mathrm{CO}_{2}$ Reduction by $\mathrm{TiO}_{2}$ and Related Titanium Containing Solids. Energy Environ. Sci. 2012, 5, 9217-9233.

46. Nocera, D.G. The Artificial Leaf. Acc. Chem. Res. 2012, 45, 767-776.

47. Hoffmann, M.R.; Moss, J.A.; Baum, M.M. Artificial Photosynthesis: Semiconductor Photocatalytic Fixation of $\mathrm{CO}_{2}$ to Afford Higher Organic Compounds. Dalton Trans. 2011, 40, 5151-5158.

48. Ismail, A.A.; Bahnemann, D.W. Photochemical Splitting of Water for Hydrogen Production by Photocatalysis: A Review. Sol. Energy Mater. Sol. Cells 2014, 128, 85-101.

49. Hisatomi, T.; Kubota, J.; Domen, K. Recent Advances in Semiconductors for Photocatalytic and Photoelectrochemical Water Splitting. Chem. Soc. Rev. 2014, 43, 7520-7535.

50. Maeda, K. Z-Scheme Water Splitting Using Two Different Semiconductor Photocatalysts. ACS Catal. 2013, 3, 1486-1503.

51. Yang, J.; Wang, D.; Han, H.; Li, C. Roles of Cocatalysts in Photocatalysis and Photoelectrocatalysis. Acc. Chem. Res. 2013, 46, 1900-1909.

52. Horiuchi, Y.; Toyao, T.; Takeuchi, M.; Matsuoka, M.; Anpo, M. Recent Advances in Visible-Light-Responsive Photocatalysts for Hydrogen Production and Solar Energy Conversion-From Semiconducting $\mathrm{TiO}_{2}$ to MOF/PCP Photocatalysts. Phys. Chem. Chem. Phys. 2013, 15, 13243-13253.

53. Yang, J.; Yan, H.; Zong, X.; Wen, F.; Liu, M.; Li, C. Roles of Cocatalysts in Semiconductor-Based Photocatalytic Hydrogen Production. Philos. Trans. R. Soc. A 2013, 371, 20110430.

54. Cargnello, M.; Diroll, B.T. Tailoring Photocatalytic Nanostructures for Sustainable Hydrogen Production. Nanoscale 2014, 6, 97-105.

55. Cargnello, M.; Gasparotto, A.; Gombac, V.; Montini, T.; Barreca, D.; Fornasiero, P. Photocatalytic $\mathrm{H}_{2}$ and Added-Value By-Products-The Role of Metal Oxide Systems in Their Synthesis from Oxygenates. Eur. J. Inorg. Chem. 2011, 28, 4309-4323. 
56. Navarro, R.M.; Sánchez-Sánchez, M.C.; Alvarez-Galvan, M.C.; del Valle, F.; Fierro, J.L.G. Hydrogen Production from Renewable Sources: Biomass and Photocatalytic Opportunities. Energy Environ. Sci. 2009, 2, 35-54.

57. Smestad, G.P.; Steinfeld, A. Review: Photochemical and Thermochemical Production of Solar Fuels from $\mathrm{H}_{2} \mathrm{O}$ and $\mathrm{CO}_{2}$ using Metal Oxide Catalysts. Ind. Eng. Chem. Res. 2012, 51, 11828-11840.

58. McKone, J.R.; Lewis, N.S.; Gray, H.B. Will Solar-Driven Water-Splitting Devices See the Light of Day? Chem. Mater. 2013, 26, 407-414.

59. Nielander, A.C.; Shaner, M.R.; Papadantonakis, K.M.; Francis, S.A.; Lewis, N.S. A Taxonomy for Solar Fuels Generators. Energy Environ. Sci. 2015, 8, 16-25.

60. Pinaud, B.A.; Benck, J.D.; Seitz, L.C.; Forman, A.J.; Chen, Z.; Deutsch, T.G.; James, B.D.; Baum, G.N.; Ardo, S.; Wang, H.; et al. Technical and Economic Feasibility of Centralized Facilities for Solar Hydrogen Production via Photocatalysis and Photoelectrochemistry. Energy Environ. Sci. 2013, 6, 1983-2002.

61. Brillet, J.; Yum, J.H.; Cornuz, M.; Hisatomi, T.; Solarska, R.; Augustynski, J.; Graetzel, M.; Sivula, K. Highly Efficient Water Splitting by a Dual-Absorber Tandem Cell. Nat. Photon. 2012, 6, 824-828.

62. Reece, S.Y.; Hamel, J.A.; Sung, K.; Jarvi, T.D.; Esswein, A.J.; Pijpers, J.J.H.; Nocera, D.G. Wireless Solar Water Splitting Using Silicon-Based Semiconductors and Earth-Abundant Catalysts. Science 2011, 334, 645-648.

63. McKone, J.R.; Marinescu, S.C.; Brunschwig, B.S.; Winkler, J.R.; Gray, H.B. Earth-Abundant Hydrogen Evolution Electrocatalysts. Chem. Sci. 2014, 5, 865-878.

64. Bozic-Weber, B.; Constable, E.C.; Housecroft, C.E. Light Harvesting with Earth-Abundant d-Block Metals: Development of Sensitizers in Dye-Sensitized Solar Cells (DSCs). Coord. Chem. Rev. 2013, 257, 3089-3106.

65. Thoi, V.S.; Sun, Y.J.; Long, J.R.; Chang, C.J. Complexes of Earth-Abundant Metals for Catalytic Electrochemical Hydrogen Generation under Aqueous Conditions. Chem. Soc. Rev. 2013, 42, 2388-2400.

66. Tran, P.D.; Pramana, S.S.; Kale, V.S.; Nguyen, M.; Chiam, S.Y.; Batabyal, S.K.; Wong, L.H.; Barber, J.; Loo, J. Novel Assembly of an $\mathrm{MoS}_{2}$ Electrocatalyst onto a Silicon Nanowire Array Electrode to Construct a Photocathode Composed of Elements Abundant on the Earth for Hydrogen Generation. Chem. Eur. J. 2012, 18, 13994-13999.

67. Du, P.W.; Eisenberg, R. Catalysts Made of Earth-Abundant Elements (Co, Ni, Fe) for Water Splitting: Recent Progress and Future Challenges. Energy Environ. Sci. 2012, 5, 6012-6021.

68. Vesborg, P.C.K.; Jaramillo, T.F. Addressing the Terawatt Challenge: Scalability in the Supply of Chemical Elements for Renewable Energy. RSC Adv. 2012, 2, 7933-7947.

69. Bolton, J.R.: Strickler, S.J; Connolly, J.S. Limiting and Realizable Efficiencies of Solar Photolysis of Water. Nature 1985, 316, 495-500.

70. Archer, M.D; Bolton, J.R. Requirements for Ideal Performance of Photochemical and Photovoltaic Solar Energy Converters. J. Phys. Chem. 1990, 94, 8028-8036.

71. Bolton, J.R. Solar Photoproduction of Hydrogen: A Review. Sol. Energy 1996, 57, 37-50. 
72. Smestad, G.P; Krebs, F.C; Lampert, C.M; Granqvist, C.G.; Chopra, K.L.; Mathew, X.; Takakura, H. Reporting Solar Cell Efficiencies in Solar Energy Materials and Solar Cells. Sol. Energy Mater. Sol. Cells 2008, 92, 371-373.

73. Emeline, A.V.; Kuznetsov, V.N.; Ryabchuk, V.K.; Serpone, N. On the Way to the Creation of Next Generation Photoactive Materials. Environ. Sci. Pollut. Res. 2012, 19, 3666-3675.

74. Serpone, N.; Emeline, A.V. Semiconductor Photocatalysis-Past, Present, and Future Outlook. J. Phys. Chem. Lett. 2012, 3, 673-677.

75. Bard, A.J. Photoelectrochemistry and Heterogeneous Photocatalysis at Semiconductors. J. Photochem. 1979, 10, 59-75.

76. Grätzel, M. Photoelectrochemical Cells. Nature 2001, 414, 338-344.

77. Luo, J.; Im, J.H.; Mayer, M.T.; Schrieier, M.; Nazeeruddin, K.; Park, N.G.; Tilley, S.D.; Fan, H.J.; Grätzel, M. Water Photolysis at 12.3\% Efficiency via Perovskite Photovoltaics and Earth-Abundant Catalysts. Science 2014, 345, 1593-1596.

78. Cox, C.R.; Lee, J.Z.; Nocera, D.G.; Buonassisi, T. Ten-Percent Solar-to-Fuel Conversion with Nonprecious Materials. Proc. Natl. Acad. Sci. USA 2014, 111, 14057-14061.

79. Rongé, J.; Bosserez, T.; Martel, D.; Nervi, C.; Boarino, L.; Taulelle, F.; Decher, G.; Bordiga, S.; Martens, J.A. Monolithic Cells for Solar Fuels. Chem. Soc. Rev. 2014, 43, 7963-7981.

80. Fujishima, A.K.; Honda, K. Electrochemical Photolysis of Water at a Semiconductor Electrode. Nature 1972, 238, 37-38.

81. Borgarello, E.; Kiwi, J.; Pelizzetti, E.; Visca, M.; Graetzel, M. Photochemical Cleavage of Water by Photocatalysis. Nature 1981, 289, 158-160.

82. Wang, Z.; Liu, Y.; Huang, B.; Dai, Y.; Lou, Z.; Wang, G.; Zhang, X.; Qin, X. Progress on Extending the Light Absorption Spectra of Photocatalysts. Phys. Chem. Chem. Phys. 2014, 16, 2758-2774.

83. Varghese, O.K.; Grimes, C.A. Appropriate Strategies for Determining the Photoconversion Efficiency of Water Photoelectrolysis Cells: A Review with Examples using Titania Nanotube Array Photoanodes. Sol. Energy Mater. Sol. Cells 2008, 92, 374-384.

84. Grätzel, M. Conversion of Sunlight to Electric Power by Nanocrystalline Dye-Sensitized Solar Cells. J. Photochem. Photobiol. A 2004, 164, 3-14.

85. Mathew, S.; Yella, A.; Gao, P.; Humphry-Baker, R.; Churchod, B.F.E.; Ashari-Astani, N.; Tavernelli, I.; Rothlisberger, U.; Nazeeruddin, M.K.; Grätzel, M. Dye-Sensitized Solar Cells with $13 \%$ Efficiency Achieved through the Molecular Engineering of Porphyrin Sensitizers. Nat. Chem. 2014, 6, 242-247.

86. Hardin, B.E.; Snaith, H.J.; McGehee, M.D. The Renaissance of Dye-Sensitized Solar Cells. Nat. Photon. 2012, 6, 162-169.

87. Li, L.L.; Diau, E.W. Porphyrin-Sensitized Solar Cells. Chem. Soc. Rev. 2013, 42, 291-304.

88. Balasingam, S.K.; Lee, M.; Kang, M.G.; Jun, Y. Improvement of Dye-Sensitized Solar Cells Toward the Broader Light Harvesting of the Solar Spectrum. Chem. Commun. 2013, 49, 1471-1487.

89. Macor, L.; Fungo, F.; Tempesti, T.; Durantini, E.N.; Otero, L.; Barea, E.M.; Fabregat-Santiago, F.; Bisquert, J. Near-IR Sensitization of Wide Band Gap Oxide Semiconductor by Axially Anchored Si-Naphthalocyanines. Energy Environ. Sci. 2009, 2, 529-534.

90. Ono, T.; Yamaguchi, T.; Arakawa, H. Study on Dye-Sensitized Solar Cell using Novel Infrared Dye. Sol. Energy Mater. Sol. Cells 2009, 93, 831-835. 
91. Altobello, S.; Argazzi, R.; Caramori, S.; Contado, C.; da Fré, S.; Rubino, P.; Chon, C.; Larramona, G.; Bignozzi, C.A. Sensitization of Nanocrystalline $\mathrm{TiO}_{2}$ with Black Absorbers based on Os and $\mathrm{Ru}$ Polypyridine Complexes. J. Am. Chem. Soc. 2005, 127, 15342-15343.

92. Persson, P.; Bergstrom, R.; Lunell, S. Quantum Chemical Study of Photoinjection Processes in Dye-sensitized $\mathrm{TiO}_{2}$ Nanoparticles. J. Phys. Chem. B 2000, 104, 10348-10351.

93. Ooyama, Y.; Yamada, T.; Fujita, T.; Harima, Y.; Ohshita, J. Development of D- $\pi$-Cat Fluorescent Dyes with a Catechol Group for Dye-Sensitized Solar Cells based on Dye-to- $\mathrm{TiO}_{2}$ Charge Transfer. J. Mater. Chem. A 2014, 2, 8500-8511.

94. Pratik, S.M.; Datta, A. Computational Design of Concomitant Type-I and Type-II Porphyrin Sensitized Solar Cells. Phys. Chem. Chem. Phys. 2013, 15, 18471-18481.

95. Zhang, G.; Kim, G.; Choi, W. Visible-light driven photocatalysis mediated via ligand-to-metal charge transfer (LMCT): An alternative approach to solar activation of Titania. Energy Environ. Sci. 2014, 7, 954-966.

96. Cheng, Y.H.; Subramaniam, V.P.; Gong, D.G.; Tang, Y.; Highfield, J.; Pehkonen, S.O.; Pichat, P.; Schreyer, M.K.; Chen, Z. Nitrogen-Sensitized Dual Phase Titanate/Titania for Visible-Light Driven Phenol Degradation. J. Solid State Chem. 2012, 196, 518-527.

97. Grätzel, M. The Light and Shade of Perovskite Solar Cells. Nat. Mater. 2014, 13, 838-842.

98. Green, M.A.; Ho-Baillie, A.; Snaith, H.J. The Emergence of Perovskite Solar Cells. Nat. Photon. 2014, 8, 506-514.

99. Gao, P.; Grätzel, M.; Nazeeruddin, M.K. Organohalide lead perovskites for photovoltaic applications. Energy Environ. Sci. 2014, 7, 2448-2463.

100. Kazim, S.; Nazeeruddin, M.K.; Grätzel, M.; Ahmad, S. Perovskite as Light Harvester: A Game Changer in Photovoltaics. Angew. Chem. Int. Ed. 2014, 53, 2812-2824.

101. Nowotny, M.K.; Sheppard, L.R.; Bak, T.; Nowotny, J. Defect Chemistry of Titanium Dioxide. Application of Defect Engineering in Processing of $\mathrm{TiO}_{2}$-Based Photocatalysts. J. Phys. Chem. C 2008, 112, 5275-5300.

102. Mizushima, K.; Tanaka, M.; Asai, A.; Iiga, S.; Goodenough, J.B. Impurity levels of Iron-Group Ions in $\mathrm{TiO}_{2}$ (II). J. Phys. Chem. Solids 1979, 40, 1129-1140.

103. Choi, W.; Termin, A.; Hoffmann, M.R. The Role of Metal Ion Dopants in Quantum-Sized $\mathrm{TiO}_{2}$ : Correlation between Photoreactivity and Charge Carrier Recombination Dynamics. J. Phys. Chem. 1994, 98, 13669-13679.

104. Moser, J.; Grätzel, M.; Gallay, R. Inhibition of Electron-Hole Recombination in Substitution-ally Doped Colloidal Semiconductor Crystallites. Helv. Chim. Acta 1987, 70, 1596-1604.

105. Choi, J.; Park, H.; Hoffmann, M.R. Effects of Single Metal-Ion Doping on the Visible-Light Photoreactivity of $\mathrm{TiO}_{2}$. J. Phys. Chem. C 2010, 114, 783-792.

106. Kernazhitsky, L.; Shymanovska, V.; Gavrilko, T.; Naumov, V.; Kshnyakin, V.; Khalyavka, T. A Comparative Study of Optical Absorption and Photocatalytic Properties of Nanocrystalline Single-Phase Anatase and Rutile $\mathrm{TiO}_{2}$ Doped with Transition Metal Cations. J. Solid State Chem. 2013, 198, 511-519.

107. Maeda, K. (Oxy)nitrides with $\mathrm{d}^{\circ}$-Electronic Configuration as Photocatalysts and Photoanodes that Operate under a Wide Range of Visible Light for Overall Water Splitting. Phys. Chem. Chem. Phys. 2013, 15, 10537-10548. 
108. Teoh, W.Y.; Scott, J.A.; Amal, R. Progress in Heterogeneous Photocatalysis: From Classical Radical Chemistry to Engineering Nanomaterials and Solar Reactors. J. Phys. Chem. Lett. 2012, 3, 629-639.

109. Chen, X.B.; Liu, L.; Yu, P.Y.; Mao, S.S. Increasing Solar Absorption for Photocatalysis with Black Hydrogenated Titanium Dioxide Nanocrystals. Science 2011, 331, 746-750.

110. Pesci, F.M.; Wang, G.; Klug, D.R.; Li, Y.; Cowan, A.J. Efficient Suppression of Electron-Hole Recombination in Oxygen-Deficient Hydrogen-Treated $\mathrm{TiO}_{2}$ Nanowires for Photoelectro-chemical Water Splitting. J. Phys. Chem. C 2013, 117, 25837-25844.

111. Liu, L.; Yu, P.Y.; Chen, X.; Mao, S.S.; Shen, D.Z. Hydrogenation and Disorder in Engineered Black TiO2. Phys. Rev. Lett. 2013, 111, 065505-(1-5).

112. Su, J.; Zou, X.; Chen, J.S. Self-Modification of Titanium Dioxide Materials by $\mathrm{Ti}^{3+}$ and/or Oxygen Vacancies: New Insights into Defect Chemistry of Metal Oxides. RSC Adv. 2014, 4, 13979-13988.

113. Fresno, F.; Portela, R.; Suárez, S.; Coronado, J.M. Photocatalytic Materials: Recent Achievements and Near Future Trends. J. Mater. Chem. A 2014, 2, 2863-2884.

114. Asahi, R.; Morikawa, T.; Ohwaki, T.; Aoki, K.; Taga, Y. Visible-Light Photocatalysis in Nitrogen-Doped Titanium Oxides. Science 2001, 293, 269-271.

115. Khan, S.U.M.; al-Shahry, M.; Ingler, W.B. Efficient Photochemical Water Splitting by a Chemically Modified n-TiO 2 . Science 2002, 297, 2243-2245.

116. Diwald, O.; Thompson, T.L.; Goralski, E.G.; Walck, S.D.; Yates, J.T. The Effect of Nitrogen Ion Implantation on the Photoactivity of $\mathrm{TiO}_{2}$ Rutile Single Crystals. J. Phys. Chem. B 2004, 108, $52-57$.

117. Di Valentin, C.; Pacchioni, G.; Selloni, A. Origin of the Different Photoactivity of N-Doped Anatase and Rutile $\mathrm{TiO}_{2}$. Phys. Rev. B 2004, 70, 085116.

118. Nakamura, R.; Tanaka, T.; Nakato, Y. Mechanism for Visible Light Responses in Anodic Photocurrents at N-Doped $\mathrm{TiO}_{2}$ Film Electrodes. J. Phys. Chem. B 2004, 108, 10617-10620.

119. Choi, Y.; Umebayashi, T.; Yoshikawa, M. Fabrication and Characterization of C-Doped Anatase $\mathrm{TiO}_{2}$ Photocatalysts. J. Mater. Sci. 2004, 39, 1837-1839.

120. Yu, J.C.; Yu, J.G.; Ho, W.K.; Jiang, Z.T.; Zhang, L.Z. Effects of F-Doping on the Photocatalytic Activity and Microstructures of Nanocrystalline $\mathrm{TiO}_{2}$ Powders. Chem. Mater. 2002, 14, 3808-3816.

121. Ohno, T.; Akiyoshi, M.; Umebayashi, T.; Asai, K.; Mitsui, T.; Matsumura, M. Preparation of S-Doped $\mathrm{TiO}_{2}$ Photocatalysts and Their Photocatalytic Activities under Visible Light. Appl. Catal. A Gen. 2004, 265, 115-121.

122. Lin, L.; Lin, W.; Zhu, Y.X.; Zhao, B.Y.; Xie, Y.C. Phosphor-Doped Titania-A Novel Photocatalyst Active in Visible Light. Chem. Lett. 2005, 34, 284-285.

123. Yin, S.; Ihara, K.; Aita, Y.; Komatsu, M.; Sato, T. Visible-Light Induced Photocatalytic Activity of $\mathrm{TiO}_{(2-\mathrm{x})} \mathrm{A}(\mathrm{y})(\mathrm{A}=\mathrm{N}, \mathrm{S})$ Prepared by Precipitation Route. J. Photochem. Photobiol. A Chem. 2006, 179, 105-114.

124. Chen, D.M.; Jiang, Z.Y.; Geng, J.Q.; Wang, Q.; Yang, D. Carbon and Nitrogen Co-Doped $\mathrm{TiO}_{2}$ with Enhanced Visible-Light Photocatalytic Activity. Ind. Eng. Chem. Res. 2007, 46, 2741-2746.

125. In, S.; Orlov, A.; Berg, R.; Garcia, F.; Pedrosa-Jimenez, S.; Tikhov, M.S.; Wright, D.S.; Lambert, R.M. Effective Visible Light-Activated B-Doped and B,N-Co-Doped $\mathrm{TiO}_{2}$ Photocatalysts. J. Am. Chem. Soc. 2007, 129, 13790-13791. 
126. Di Valentin, C.; Finazzi, E.; Pacchioni, G.; Selloni, A.; Livraghi, S.; Paganini, M.C.; Giamello, E.; N-Doped $\mathrm{TiO}_{2}$ : Theory and Experiment. Chem. Phys. 2007, 339, 44-56.

127. Harb, M.; Sautet, P.; Raybaud, P. Origin of the Enhanced Visible-Light Absorption in N-Doped Bulk Anatase $\mathrm{TiO}_{2}$ from First-Principles Calculations. J. Phys. Chem. C2011, 115, 19394-19404.

128. Marschall, R.; Wang, L.Z. Non-Metal Doping of Transition Metal Oxides for Visible-Light Photocatalysis. Catal. Today 2014, 225, 111-135.

129. Gomathi Devi, L.; Kavitha, R. Review on Modified $\mathrm{N}_{-} \mathrm{TiO}_{2}$ for Green Energy Applications under UV/Visible Light: Selected Results and Reaction Mechanisms. RSC Adv. 2014, 4, 28265-28299.

130. Asahi, R.; Morikawa, T.; Irie, H.; Ohwaki, T. Nitrogen-Doped Titanium Dioxide as Visible-Light-Sensitive Photocatalyst: Designs, Developments, and Prospects. Chem. Rev. 2014, 114, 9824-9852.

131. Mrowetz, M.; Balcerski, W.; Colussi, A.J.; Hoffmann, M.R. Oxidative Power of Nitrogen-Doped $\mathrm{TiO}_{2}$ Photocatalysts under Visible Illumination. J. Phys. Chem. B 2004, 108, 17269-17273.

132. Lindgren, T.; Lu, J.; Hoel, A.; Granqvist, C.G.; Torres, G.R.; Lindquist, S.E. Photoelectrochemical Study of Sputtered Nitrogen-Doped Titanium Dioxide Thin Films in Aqueous Electrolyte. Sol. Energy Mater. Sol. Cells 2004, 84, 145-157.

133. Tang, J.; Cowan, A.J.; Durrant, J.R.; Klug, D.R. Mechanism of $\mathrm{O}_{2}$ Production from Water Splitting: Nature of Charge Carriers in Nitrogen Doped Nanocrystalline $\mathrm{TiO}_{2}$ Films and Factors Limiting $\mathrm{O}_{2}$ Production. J. Phys. Chem. C 2011, 115, 3143-3150.

134. Di Valentin, C.; Pacchioni, G. Trends in Non-Metal Doping of Anatase $\mathrm{TiO}_{2}$ : B, C, N and F. Catal. Today 2013, 206, 12-18.

135. Yin, W.J.; Tang, H.W.; Wei, S.H.; Al-Jassim, M.M.; Turner, J.; Yan, Y.F. Band Structure Engineering of Semiconductors for Enhanced Photoelectrochemical Water Splitting: The Case of $\mathrm{TiO}_{2}$. Phys. Rev. B 2010, 82, 045106-(1-6).

136. Zhu, W.; Qiu, X.; Iancu, V.; Chen, X.Q.; Pan, H.; Wang, W.; Dimitrijevic, N.M.; Rajh, T.; Meyer, H.M., III; Paranthaman, M.P.; et al. Band Gap Narrowing of Titanium Oxide Semiconductors by Non-Compensated Anion-Cation Codoping for Enhanced Visible Light Photoactivity. Phys. Rev. Lett. 2009, 103, 226401:1-226401:4.

137. Czoska, A.M.; Livraghi, S.; Paganini, M.C.; Giamello, E.; di Valentin, C.; Pacchioni, G. The Nitrogen-Boron Paramagnetic Center in Visible Light-Sensitized N-B-Codoped $\mathrm{TiO}_{2}$. Experimental and Theoretical Characterization. Phys. Chem. Chem. Phys. 2011, 13, 136-143.

138. Balcerski, W.; Ryu, S.Y.; Hoffmann, M.R. Visible-Light Photoactivity of Nitrogen-Doped $\mathrm{TiO}_{2}$ : Photo-Oxidation of $\mathrm{HCO}_{2} \mathrm{H}$ to $\mathrm{CO}_{2}$ and $\mathrm{H}_{2} \mathrm{O}$. J. Phys. Chem. C 2007, 111, 15357-15362.

139. Mitoraj, D.; Kisch, H. The Nature of Nitrogen-Modified Titanium Dioxide Photocatalysts Active in Visible Light. Angew. Chem. Int. Ed. 2008, 47, 9975-9978.

140. Mitoraj, D.; Kisch, H. On the Mechanism of Urea-Induced Titania Modification. Chem. Eur. J. 2010, 16, 261-269.

141. Ang, T.P.; Chan, Y.M. Comparison of the Melon Nanocomposites in Structural Properties and Photocatalytic Activities. J. Phys. Chem. C2011, 115, 15965-15972.

142. Gong, D.; Highfield, J.G.; Zhong, E.N.; Tang, Y.; Ho, W.C.J.; Tay, Q.; Chen, Z. Poly Tri-s-triazines as Visible Light Sensitizers in Titania-Based Composite Photocatalysts: Promotion of Melon Development from Urea over Acid Titanates. ACS Sustain. Chem. Eng. 2014, 2, 149-157. 
143. Wang, Y.; Wang, X.; Antonietti, M. Polymeric Graphitic Carbon Nitride as a Heterogeneous Organocatalyst: From Photochemistry to Multipurpose Catalysis to Sustainable Chemistry. Angew. Chem. Int. Ed. 2012, 51, 68-89.

144. Gole, J.L.; Stout, J.D.; Burda, C.; Lou, Y.; Chen, X. Highly Efficient Formation of Visible-Light Tunable $\mathrm{TiO}_{2-\mathrm{x}} \mathrm{N}_{\mathrm{x}}$ Photocatalysts and Their Transformation at the Nanoscale. J. Phys. Chem. B 2004, 108, 1230-1240.

145. Cantau, C.; Pigot, T.; Dupin. J.C.; Lacombe, S. N-Doped $\mathrm{TiO}_{2}$ by Low Temperature Synthesis: Stability, Photo-Reactivity, and Singlet Oxygen Formation in the Visible Range. J. Photochem. Photobiol. A Chem. 2010, 216, 201-208.

146. Spadavecchia, F.; Cappelletti, G.; Ardizzone, S.; Bianchi, C.L.; Cappelli, S.; Oliva, C.; Scardi, P.; Leoni, M.; Fermo, P. Solar Photoactivity of Nano-N-TiO 2 from Tertiary Amine: Role of Defects and Paramagnetic Species. Appl. Catal. B: Environ. 2010, 96, 314-322.

147. Cheng, Y.H.; Huang, Y.; Kanhere, P.D.; Subramaniam, V.P.; Gong, D.; Zhang, S.; Highfield, J.; Schreyer, M.K.; Chen, Z. Dual-Phase Titanate/Anatase with Nitrogen Doping for Enhanced Degradation of Organic Dye under Visible Light. Chem. Eur. J. 2011, 17, 2575-2578.

148. Zhao, Y.; Qiu, X.; Burda, C. The Effects of Sintering on the Photocatalytic Activity of N-doped $\mathrm{TiO}_{2}$ Nanoparticles. Chem. Mater. 2008, 20, 2629-2636.

149. Tian, Y.; Tatsuma, T. Mechanisms and Applications of Plasmon-Induced Charge Separation at $\mathrm{TiO}_{2}$ Films Loaded with Gold Nanoparticles. J. Am. Chem. Soc. 2005, 127, 7632-7637.

150. Kowalska, E.; Mahaney, O.O.P.; Abe, R.; Ohtani, B. Visible-Light-Induced Photocatalysis through Surface Plasmon Excitation of Gold on Titania Surfaces. Phys. Chem. Chem. Phys. 2010, 12, 2344-2355.

151. Gong, D.; Ho, W.C.J.; Tang, Y.; Tay, Q.; Lai, Y.; Highfield, J.G.; Chen, Z. Silver-Decorated Titanate/Titania Nanostructures for Efficient Solar Driven Photocatalysis. J. Solid State Chem. 2012, 189, 117-122.

152. Sellapan, R.; Nielsen, M.G.; Gonzalez-Posada, F.; Vesborg, P.C.K.; Chorkendorff, I.; Chakarov, D. Effects of Plasmon Excitation on Photocatalytic Activity of $\mathrm{Ag} / \mathrm{TiO}{ }_{2}$ and $\mathrm{Au} / \mathrm{TiO}_{2}$ Nanocomposites. J. Catal. 2013, 307, 214-221.

153. Mubeen, S.; Lee, J.; Singh, N.; Krämer, S.; Stucky, G.D.; Moskovits, M. An autonomous photosynthetic device in which all charge carriers derive from surface Plasmons. Nat. Nanotechnol. 2013, 8, 247-251.

154. Ma, X.; Dai, Y.; Yu, L.; Huang, B. New Basic Insights into the Low Hot Electron Injection Efficiency of Gold-Nanoparticle-Photosensitized Titanium Dioxide. ACS Appl. Mater. Interfaces 2014, 6, 12388-12394.

155. Clavero, C. Plasmon-Induced Hot-Electron Generation at Nanoparticle/Metal-Oxide Interfaces for Photovoltaic and Photocatalytic Devices. Nat. Photon. 2014, 8, 95-103.

156. Xu, H.; Ouyang, S.; Liu, L.; Reunchan, P.; Umezawa, N.; Ye, J. Recent Advances in $\mathrm{TiO}_{2}$-based Photocatalysis. J. Mater. Chem. A 2014, 2, 12642-12661.

157. Warren, S.C.; Thimsen, E. Plasmonic Solar Water Splitting. Energy Environ. Sci. 2012, 5, 5133-5146.

158. Linic, S.; Christopher, P.; Ingram, D.B. Plasmonic-Metal Nanostructures for Efficient Conversion of Solar to Chemical Energy. Nat. Mater. 2011, 10, 911-921. 
159. Zhou, X.M.; Liu, G.; Yu, J.G.; Fan, W.H. Surface Plasmon Resonance-Mediated Photocatalysis by Noble Metal-Based Composites under Visible Light. J. Mater. Chem. 2012, 22, 21337-21354.

160. DuChene, J.S.; Sweeny, B.C.; Johnston-Peck, A.C.; Su, D.; Stach, E.A.; Wei, W.D. Prolonged Hot Electron Dynamics in Plasmonic-Metal/Semiconductor Heterostructures with Implications for Solar Photocatalysis. Angew. Chem. Int. Ed. 2014, 53, 7887-7891.

161. Ingram, D.B.; Christopher, P.; Bauer, J.L.; Linic, S. Predictive Model for the Design of Plasmonic Metal/Semiconductor Composite Photocatalysts. ACS Catal. 2011, 1, 1441-1447.

162. Thimsen, E.; le Formal, F.; Grätzel, M.; Warren, S.C. Influence of Plasmonic Au Nanoparticles on the Photoactivity of $\mathrm{Fe}_{2} \mathrm{O}_{3}$ Electrodes for Water Splitting. Nano Lett. 2011, 11, 35-43.

163. Logar, M.; Bračko, I.; Potočnik, A.; Jančar, B. Cu and CuO/Titanate Nanobelt Based Network Assemblies for Enhanced Visible Light Photocatalysis. Langmuir 2014, 30, 4852-4862.

164. Nogawa, T.; Isobe, T.; Matsushita, S.; Nakajima, A. Preparation and Visible-Light Photo-catalytic Activity of Au- and $\mathrm{Cu}$-modified $\mathrm{TiO}_{2}$ Powders. Mater. Lett. 2012, 82, 174-177.

165. Kazuma, E.; Yamaguchi, T.; Sakai, N.; Tatsuma, T. Growth Behaviour and Plasmon Resonance Properties of Photocatalytically Deposited Cu Nanoparticles. Nanoscale 2011, 3, 3641-3645.

166. Knight, M.W.; King, N.S.; Liu, L.; Everitt, H.O.; Nordlander, P.; Halas, N.J. Aluminum for Plasmonics. ACS Nano 2014, 8, 834-840.

167. Lounis, S.D.; Runnerstrom, E.L.; Llordés, Milliron, D.J. Defect Chemistry and Plasmon Physics of Colloidal Metal Oxide Nanocrystals. J. Phys. Chem. Lett. 2014, 5, 1564-1574.

168. Henderson, M.A. A Surface Science Perspective on $\mathrm{TiO}_{2}$ Photocatalysis. Surf. Sci. Rep. 2011, 66, $185-297$.

169. Hernández-Alonso, M.D.; Fresno, F.; Suárez, S.; Coronado, J.M. Development of Alternative Photocatalysts to $\mathrm{TiO}_{2}$ : Challenges and Opportunities. Energy Environ. Sci. 2009, 2, 1231-1257.

170. Chen, X.; Mao, S.S. Titanium Dioxide Nanomaterials: Synthesis, Properties, Modifications, and Applications. Chem. Rev. 2007, 107, 2891-2959.

171. Zhang, J.; Xu, Q.; Li, M.; Li, C. Importance of the Relationship between Surface Phases and Photocatalytic Activity of $\mathrm{TiO}_{2}$. Angew. Chem. Int. Ed. 2008, 47, 1766-1769.

172. Li, G.; Gray, K.A. The Solid-Solid Interface: Explaining the High and Unique Photocatalytic Reactivity of $\mathrm{TiO}_{2}$-Based Nanocomposite Materials. Chem. Phys. 2007, 339, 173-187.

173. Chen, X.; Selloni, A. Introduction: Titanium Dioxide $\left(\mathrm{TiO}_{2}\right)$ Nanomaterials. Chem. Rev. 2014, 114, 9281-9282.

174. Kapilashrami, M.; Zhang, Y.; Liu, Y.S.; Hagfeldt, A.; Guo, J. Probing the Optical Property and

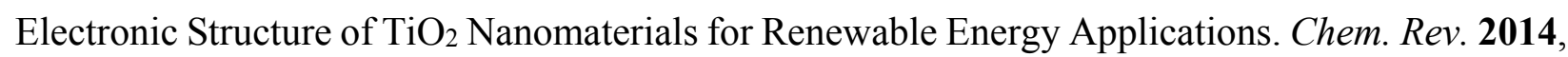
114, 9662-9707.

175. Schneider, J.; Matsuoka, M.; Takeuchi, M.; Zhang, J.; Horiuchi, Y.; Anpo, M.; Bahnemann, D.W. Understanding $\mathrm{TiO}_{2}$ Photocatalysis: Mechanisms and Materials. Chem. Rev. 2014, 114, 9919-9986.

176. Di Iorio, Y.; Aguirre, M.E.; Brusam M.A.; Grela, M.A. Surface Chemistry Determines Electron Storage Capabilities in Alcoholic Sols of Titanium Dioxide Nanoparticles. A Combined FTIR and Room Temperature EPR Investigation. J. Phys. Chem. C 2012, 116, 9646-9652.

177. Murakami, N.; Mahaney, O.O.P.; Abe, R.; Torimoto, T.; Ohtani, B. Double-Beam Photo- acoustic Spectroscopic Studies on Transient Absorption of Titanium(IV) Oxide Photocatalyst Powders. J. Phys. Chem. C2007, 111, 11927-11935. 
178. Chen, T.; Feng, Z.; Wu, G.; Shi, J.; Ma, G.; Ying, P.; Li, C. Mechanistic Studies of Photocatalytic Reaction of Methanol for Hydrogen Production on $\mathrm{Pt} / \mathrm{TiO}_{2}$ by In-Situ Fourier-Transform IR and Time-Resolved IR Spectroscopy. J. Phys. Chem. C 2007, 111, 8005-8014.

179. Yamakata, A.; Ishibashi, T.; Onishi, H. Effects of Water Addition on the Methanol Oxidation on $\mathrm{Pt} / \mathrm{TiO}_{2}$ Photocatalyst Studied by Time-Resolved Infrared Absorption Spectroscopy. J. Phys. Chem. B 2003, 107, 9820-9823.

180. Szczepankiewicz, S.H.; Moss, J.A.; Hoffmann, M.R. Slow Surface Charge Trapping Kinetics on Irradiated $\mathrm{TiO}_{2}$. J. Phys. Chem. B 2002, 106, 2922-2927.

181. Highfield, J.G.; Grätzel, M. Discovery of Reversible Photochromism in Titanium Dioxide using Photoacoustic Spectroscopy: Implications for the Investigation of Light-Induced Charge Separation and Surface Redox Processes in Titanium Dioxide. J. Phys. Chem. 1988, 92, 464-467.

182. Di Valentin, C.; Selloni, A. Bulk and Surface Polarons in Photoexcited Anatase. J. Phys. Chem. Lett. 2011, 2, 2223-2228.

183. Peter, L.M.; Wijayantha, K.G.U. Photoelectrochemical Water Splitting at Semiconductor Electrodes: Fundamental Problems and New Perspectives. ChemPhysChem 2014, 15, 1983-1995.

184. Wang, X.C.; Biechert, S.; Antonietti, M. Polymeric Graphitic Carbon Nitride for Heterogeneous Photocatalysis. ACS Catal. 2012, 2, 1596-1606.

185. Martin, D.J.; Qiu, K.P.; Shevlin, S.A.; Handoko, A.D.; Chen, X.W.; Guo, Z.X.; Tang, J.W. Highly Efficient Photocatalytic $\mathrm{H}_{2}$ Evolution from Water Using Visible Light and Structure-Controlled Graphitic Carbon Nitride. Angew. Chem. Int. Ed. 2014, 53, 9240-9245.

186. Hollmann, D.; Karnahl, M.; Tschierlei, S.; Kailasam, K.; Schneider, M.; Radnik, J.; Grabow, K.; Bentrup, U.; Junge, H.; Beller, M.; et al. Structure-Activity Relationships in Bulk Polymeric and Sol-Gel Derived Carbon Nitrides During Photocatalytic Hydrogen Production. Chem. Mater. 2014, 26, 1727-1733.

187. Wirth, J.; Neumann, R.; Antonietti, M.; Saalfrank, P. Adsorption and Photocatalytic Splitting of Water on Graphitic Carbon Nitride: A First Principles and Semi-Empirical Study. Phys. Chem. Chem. Phys. 2014, 16, 15917-15926.

188. Maeda, K.; Wang, X.; Nishihara, Y.; Lu, D.; Antonietti, M.; Domen. K. Photocatalytic Activities of Graphitic Carbon Nitride Powder for Water Oxidation and Reduction under Visible Light. J. Phys. Chem. C 2009, 113, 4940-4947.

189. Wang, X.; Pehkonen, S.O.; Rämö, J.; Väänänen, M.; Highfield, J.G.; Laasonen, K. Experimental and Computational Studies of Nitrogen-Doped Degussa P25 TiO2: Application to Visible-Light Driven Photo-Oxidation of As (III). Catal. Sci. Technol. 2012, 2, 784-793.

190. Sivula, K.; le Formal, F.; Grätzel, M. Solar Water Splitting: Progress Using Hematite $\left(\alpha-\mathrm{Fe}_{2} \mathrm{O}_{3}\right)$ Photoelectrodes. ChemSusChem 2011, 4, 432-449.

191. Warren, S.C.; Voitchovsky, K.; Dotan, H.; Leroy, C.M.; Cornuz, M.; Stellacci, F.; Hébert, C.; Rothschild, A.; Grätzel, M. Identifying Champion Nanostructures for Solar Water-Splitting. Nat. Mater. 2013, 12, 842-849.

192. Shinar, R.; Kennedy, J.H. Photoactivity of Doped $\alpha-\mathrm{Fe}_{2} \mathrm{O}_{3}$ Electrodes. Sol. Energy Mater. 1982, 6 , 323-335.

193. Dare-Edwards, M.P.; Goodenough, J.B.; Hamnett, A.; Trevellick, P.R. Electrochemistry and Photoelectrochemistry of Iron(III) Oxide. J. Chem. Soc. Faraday Trans. I 1983, 79, 2027-2041. 
194. Itoh, K.; Bockris, J.O. Thin Film Photoelectrochemistry: Iron Oxide. J. Electrochem. Soc. 1984, 131, 1266-1271.

195. Kennedy, J.H.; Frese, K.W. Photooxidation of Water at $\alpha-\mathrm{Fe}_{2} \mathrm{O}_{3}$ Electrodes. J. Electrochem. Soc. 1978, 125, 709-714.

196. Wang, K.X.Z.; Wu, Z.F.; Liu, V.; Brongersma, M.L.; Jaramillo, T.F.; Fan, S.H. Nearly Total Solar Absorption in Ultrathin Nanostructured Iron Oxide for Efficient Photoelectrochemical Water Splitting. ACS Photon. 2014, 1, 235-240.

197. Wheeler, D.A.; Wang, G.M.; Ling, Y.C.; Li, Y.; Zhang, J.Z. Nanostructured hematite: Synthesis, characterization, charge carrier dynamics, and photoelectrochemical properties. Energy Environ. Sci. 2012, 5, 6682-6702.

198. Pendlebury, S.R.; Cowan, A.J.; Barroso, M.; Sivula, K.; Ye, J.; Grätzel, M.; Klug, D.R.; Tang, J.; Durrant, J.R. Correlating Long-Lived Photogenerated Hole Populations with Photocurrent Densities in Hematite Water Oxidation Photoanodes. Energy Environ. Sci. 2012, 5, 6304-6312.

199. Le Formal, F.; Pendlebury, S.R.; Cornuz, M.; Tilley, S.D.; Grätzel, M.; Durrant, J.R. Back Electron-Hole Recombination in Hematite Photoanodes for Water Splitting. J. Am. Chem. Soc. 2014, 136, 2564-2574.

200. Peter, L.M. Energetics and Kinetics of Light-Driven Oxygen Evolution at Semiconductor Electrodes: The Example of Hematite. J. Solid State Electrochem. 2013, 17, 315-326.

201. Braun, A.; Sivula, K.; Bora, D.K.; Zhu, J.; Zhang, L.; Grätzel, M.; Guo, J.; Constable, E.C. Direct Observation of Two Electron Holes in a Hematite Photoanode During Photoelectro-chemical Water Splitting. J. Phys. Chem. C 2012, 116, 16870-16875.

202. Serpone, N.; Borgarello, E.; Grätzel, M. Visible Light Induced Generation of $\mathrm{H}_{2}$ from $\mathrm{H}_{2} \mathrm{~S}$ in Mixed Semiconductor Dispersions: Improved Efficiency through Interparticle Electron Transfer. J. Chem. Soc. Chem. Commun. 1984, 342-344.

203. Yan, H.; Yang, J.; Ma, G.; Wu, G.; Lei, Z.; Shi, J.; Li, C. Visible-Light-Driven Hydrogen Production with Extremely High Quantum Efficiency on Pt-PdS/CdS Photocatalyst. J. Catal. 2009, 266, 165-168.

204. Yang, J.; Yan, H.; Wang, X.; Wen, F.; Wang, Z.; Fan, D.; Shi, J.; Li, C. Roles of Cocatalysts in Pt-PdS/CdS with Exceptionally High Quantum Efficiency for Photocatalytic Hydrogen Production. J. Catal. 2012, 290, 151-157.

205. Ehsan, M.A.; Ming, H.N.; McKee, V.; Peiris, T.A.N.; Gamage, U.W.K.; Arifin, Z.; Mazhar, M.; Vysotskite Structured Photoactive Palladium Sulphide Thin Films from Dithiocarbamate. Derivatives. New J. Chem. 2014, 38, 4083-4091.

206. Ferrer, I.J.; Díaz-Chao, P.; Sánchez, C. An Investigation on Palladium Sulphide (PdS) Thin Films as a Photovoltaic Material. Thin Solid Films 2007, 515, 5783-5786.

207. Meng, J.; Yu, Z.; Li, Y.; Li, Y. PdS-Modified CdS/NiS Composite as an Efficient Photocatalyst for $\mathrm{H}_{2}$ evolution in Visible Light. Catal. Today 2014, 225, 136-141.

208. Zhang, S.; Chen, Q.; Jing, D.; Wang, Y.; Guo, L. Visible Photoactivity and Anticorrosion Performance of PdS-CdS Photocatalysts Modified by Polyaniline. Int. J. Hydrog. Energy 2012, 37, 791-796.

209. Ran, J.R.; Zhang, J.; Yu, J.G.; Jaroniec, M.; Qiao, S.Z. Earth-Abundant Cocatalysts for Semiconductor-Based Photocatalytic Water Splitting. Chem. Soc. Rev. 2014, 43, 7787-7812.

210. Dinh, C.; Pham, M.; Kleitz, F.; Do, T. Design of Water-Soluble CdS-Titanate-Nickel Nanocomposites for Photocatalytic Hydrogen production Under Sunlight. J. Mater. Chem. A 2013, 1, 13308-13313. 
211. McKone, J.R.; Warren, E.L.; Bierman, M.J.; Boettcher, S.W.; Brunscwig, B.S.; Lewis, N.S.; Gray, H.B. Evaluation of Pt, Ni, and Ni-Mo Electrocatalysts for Hydrogen Evolution on Crystalline Si Electrodes. Energy Environ. Sci. 2011, 4, 3573-3583.

212. Highfield, J.G.; Claude, E.; Oguro, K. Electrocatalytic Synergism in Ni/Mo Cathodes for Hydrogen Evolution in Acid Medium: A New Model. Electrochim. Acta 1999, 44, 2805-2814.

213. Yu, J.G.; Ran, J.R. Facile Preparation and Enhanced Photocatalytic $\mathrm{H}_{2}$-Production Activity of $\mathrm{Cu}(\mathrm{OH})_{2}$ Cluster Modified $\mathrm{TiO}_{2}$. Energy Environ. Sci. 2011, 4, 1364-1371.

214. Gagliardi, C.J.; Vannucci, A.K.; Concepcion, J.J.; Chen, Z.; Mayer, T.J. The Role of Proton Coupled Electron Transfer in Water Oxidation. Energy Environ. Sci. 2012, 5, 7704-7717.

215. Armstrong, F.A. Why Did Nature Choose Manganese to Make Oxygen? Philos. Trans. R. Soc. B 2008, 363, 1263-1270.

216. Carmo, M.; Fritz, D.L.; Mergel, J.; Stolten, D. A Comprehensive Review on PEM Water Electrolysis. Int. J. Hydrog. Energy 2013, 38, 4901-4934.

217. Fabbri, E.; Habereder, A.; Waltar, K.; Kötz, R.; Schmidt, T.J. Developments and Perspectives of Oxide-Based Catalysts for the Oxygen Evolution Reaction. Catal. Sci. Technol. 2014, 4, 3800-3821.

218. Zhang, F.; Yamakata, A.; Maeda, K.; Moriya, Y.; Takata, T.; Kubota, J.; Teshima, K.; Oishi, S.; Domen, K. Cobalt-Modified Porous Single-Crystalline $\mathrm{LaTiO}_{2} \mathrm{~N}$ for Highly Efficient Water Oxidation Under Visible Light. J. Am. Chem. Soc. 2012, 134, 8348-8351.

219. Liu, L.C.; Li, Z.Y.; Zou, W.X.; Gu, X.R.; Deng, Y.; Gao, F.; Tang, C.J.; Dong, L. In Situ Loading Transition Metal Oxide Clusters on $\mathrm{TiO}_{2}$ Nanosheets as Co-Catalysts for Exceptional High Photoactivity. ACS Catal. 2013, 3, 2052-2061.

220. Kudo, A.; Miseki, Y. Heterogeneous Photocatalytic Materials for Water Splitting. Chem. Soc. Rev. 2009, 38, 253-278.

221. Maeda, K.; Domen, K. Photocatalytic Water Splitting: Recent Progress and Future Challenges. J. Phys. Chem. Lett. 2010, 1, 2655-2661.

222. Maeda, K.; Higashi, M.; Lu, D.; Abe, R.; Domen, K. Efficient Non-Sacrificial Water Splitting through Two-Step Photoexcitation by Visible Light Using a Modified Oxynitride as a Hydrogen Evolution Photocatalyst. J. Am. Chem. Soc. 2010, 132, 5858-5868.

223. Sasaki, Y.; Nemoto, H.; Saito, K.; Kudo, A. Solar Water Splitting Using Powdered Photocatalysts Driven by Z-Schematic Interparticle Electron Transfer without an Electron Mediator. J. Phys. Chem. C 2009, 113, 17536-17542.

224. Zhou, P.; Yu, J.; Jaroniec, M. All-Solid-State Z-Scheme Photocatalytic Systems. Adv. Mater. 2014, 26, 4920-4935.

225. Wang, Y.; Wang, Q.; Zhan, X.; Wang, F.; Safdar, M.; He, J. Visible Light Driven Type II Heterostructures and Their Enhanced Photocatalysis Properties: A Review. Nanoscale 2013, 5, 8326-8339.

226. Prévot, M.S.; Sivula, K. Photoelectrochemical Tandem Cells for Solar Water Splitting. J. Phys. Chem. C 2013, 117, 17879-17893.

227. Hu, S.; Xiang, C.; Haussener, S.; Berger, A.D.; Lewis, N.S. An Analysis of the Optimal Band Gaps of Light Absorbers in Integrated Tandem Photoelectrochemical Water-Splitting Systems. Energy Environ. Sci. 2013, 6, 2984-2993. 
228. Kanan, M.W.; Nocera, D.G. In Situ Formation of an Oxygen-Evolving Catalyst in Neutral Water Containing Phosphate and $\mathrm{Co}^{2+}$. Science 2008, 321, 1072-1075.

229. Bediako, D.K.; Lasalle-Kaiser, B.; Surendranath, Y.; Yano, J.; Yachandra, V.K.; Nocera, D.G. Structure-Activity Correlations in a Nickel-Borate Oxygen Evolution Catalyst. J. Am. Chem. Soc. 2012, 134, 6801-6809.

230. Gibson, T.L.; Kelly, N.A. Optimization of Solar Powered Hydrogen Production Using Photovoltaic Electrolysis Devices. Int. J. Hydrog. Energy 2008, 33, 5931-5940.

231. Herron, J.A.; Kim, J.; Upadhye, A.A.; Huber, G.W.; Maravelias, C.T. A General Framework for the Assessment of Solar Fuel Technologies. Energy Environ. Sci. 2015, 8, 126-157.

232. Hernández-Pagán, E.A.; Vargas-Barbosa, N.M.; Wang, T.H.; Zhao, Y.; Smotkin, E.S. Resistance and Polarization Losses in Aqueous Buffer-Membrane Electrolytes for Water-Splitting Photoelectrochemical Cells. Energy Environ. Sci. 2012, 5, 7582-7589.

233. Jacobsson, T.J.; Fjällstrom, V.; Edoff, M.; Edvinsson, T. Sustainable Solar Hydrogen Production: From Photoelectrochemical cells to PV-Electrolyzers and Back Again. Energy Environ. Sci. 2014, 7, 2056-2070.

234. Tributsch, H. Photovoltaic Hydrogen Generation. Int. J. Hydrog. Energy 2008, 33, 5911-5930.

235. Campos-Martin, J.M.; Blanco-Brieva, G.; Fierro, J.L.G. Hydrogen Peroxide Synthesis: An Outlook beyond the Anthraquinone Process. Angew. Chem. Int. Ed. 2006, 45, 6962-6984.

236. García-Serna, J.; Moreno, T.; Biasi, P.; Cocero, M.J.; Mikkola, J.P.; Salmi, T.O. Engineering in Direct Synthesis of Hydrogen Peroxide: Targets, Reactors and Guidelines for Operational Conditions. Green Chem. 2014, 16, 2320-2345.

237. Samanta, C. Direct Synthesis of Hydrogen Peroxide from Hydrogen and Oxygen: An Overview of Recent Developments in the Process. Appl. Catal. A Gen. 2008, 350, 133-149.

238. Edwards, J.K.; Solsona, B.; Ntainjua, E.; Carley, A.F.; Herzing, A.A.; Kiely, C.J.; Hutchings, G.J. Switching Off Hydrogen Peroxide Hydrogenation in the Direct Synthesis Process. Science 2009, 323, 1037-1041.

239. Siahrostami, S.; Verdaguer-Casadevall, A.; Karamad, M.; Deiana, D.; Malacrida, P.; Wickman, B.; Escudero-Escribano, M.; Paoli, E.A.; Frydendal, R.; Hansen, T.W.; et al. Enabling Direct $\mathrm{H}_{2} \mathrm{O}_{2}$ Production Through Rational Electrocatalyst Design. Nat. Mater. 2013, 12, 1137-1143.

240. Sanli, A.E. A Possible Future Fuel Cell: the Peroxide/Peroxide Fuel Cell. Int. J. Energy Res. 2013, 37, 1488-1497.

241. Kato, S.; Jung, J.; Suenobu, T.; Fukuzumi, S. Production of Hydrogen Peroxide as a Sustainable Solar Fuel from Water and Dioxygen. Energy Environ. Sci. 2013, 6, 3756-3764.

242. Fukuzumi, S.; Yamada, Y.; Karlin, K.D. Hydrogen Peroxide as a Sustainable Energy Carrier: Electrocatalytic Production of Hydrogen Peroxide and the Fuel Cell. Electrochim. Acta 2012, 82, 493-511.

243. Sanli, A.E.; Aytaç, A. Response to Disselkamp: Direct Peroxide/Peroxide Fuel Cell as a Novel Type Fuel Cell. Int. J. Hydrog. Energy 2011, 36, 869-875.

244. Disselkamp, R.S. Can Aqueous Hydrogen Peroxide be used as a Standalone Energy Source? Int. J. Hydrogen Energy 2010, 35, 1049-1053. 
245. Yamazaki, S.; Siroma, Z.; Senoh, H.; Iroi, T.; Fujiwara, N.; Yasuda, K. A Fuel Cell with Selective Electrocatalysts Using Hydrogen Peroxide as Both an Electron Acceptor and a Fuel. J. Power Sources 2008, 178, 20-25.

246. Disselkamp, R.S. Energy Storage Using Aqueous Hydrogen Peroxide. Energy Fuels 2008, 22, 2771-2774.

247. Bussayajarn, N.; Harrington, D.A.; Therdthianwong, S.; Therdthianwong, A.; Djilali, N. The Cathodic Polarization Prediction of $\mathrm{H}_{2} / \mathrm{H}_{2} \mathrm{O}_{2}$ Fuel Cells using EIS Spectra. In Paper A-012, Proceedings of the 2nd Joint International Conference on Sustainable Energy \& Environment, Bankok, Thailand, 21-23 November 2006.

248. Ponce de León, Walsh, F.C.; Rose, A.; Lakeman, J.B.; Browning, D.J.; Reeve, R.W. A Direct Borohydride-Acid Peroxide Fuel Cell. J. Power Sources 2007, 164, 441-448.

249. Miley, G.H.; Luo, N.; Mather, J.; Burton, R.; Hawkins, G.; Gu, L.; Byrd, E.; Gimlin, R.; Shrestha, P.J.; Benavides, G.; et al. Direct $\mathrm{NaBH}_{4} / \mathrm{H}_{2} \mathrm{O}_{2}$ Fuel Cells. J. Power Sources 2007, 165, 509-516.

250. An, L.; Zhao, T.S.; Zhou, X.L.; Wei, L.; Yan, X.H. A High Performance Ethanol-Hydrogen Peroxide Fuel Cell. RSC Adv. 2014, 4, 65031-65034.

251. Amirfakhri, S.J.; Meunier, J.L.; Berk, D. Electrocatalytic Activity of $\mathrm{LaNiO}_{3}$ toward $\mathrm{H}_{2} \mathrm{O}_{2}$ Reduction Reaction: Minimization of Oxygen Evolution. J. Power Sources 2014, 272, 248-258.

252. Compton, O.C.; Osterloh, F.E. Niobate Nanosheets as Catalysts for Photochemical Water Splitting into Hydrogen and Hydrogen Peroxide. J. Phys. Chem. C 2009, 113, 479-485.

253. Daskalaki, V.M.; Panagiotopoulou, P.; Kondarides, D.I. Production of Peroxide Species in Pt/TiO 2 Suspensions under Conditions of Photocatalytic Water Splitting and Glycerol Photo-Reforming. Chem. Eng. J. 2011, 170, 433-439.

254. Arakawa, H. Water Photolysis by $\mathrm{TiO}_{2}$ Particles-Significant Effect of $\mathrm{Na}_{2} \mathrm{CO}_{3}$ Addition on Water Splitting. In Photocatalysis Science and Technology; Kaneko, M., Okura, I., Eds.; Springer: New York, NY, USA, 2002; p. 235.

255. Yesodharan, E.; Yesodharan, S.; Grätzel, M. Photolysis of Water with Supported Noble Metal Cluster. The Fate of Oxygen in Titania Based Water Cleavage Systems. Sol. Energy Mater. 1984, 10, 287-302.

256. Hoffman, A.J.; Carraway, E.R.; Hoffmann, M.R. Photocatalytic Production of $\mathrm{H}_{2} \mathrm{O}_{2}$ and Organic Peroxides on Quantum-Sized Semiconductor Colloids. Environ. Sci. Technol. 1994, 28, 776-785.

257. Maurino, V.; Minero, C.; Mariella, G.; Pelizzetti, E. Sustained Production of $\mathrm{H}_{2} \mathrm{O}_{2}$ on Irradiated $\mathrm{TiO}_{2}$-Fluoride Systems. Chem. Commun. 2005, 2627-2629.

258. Moon, G.M.; Kim, W.; Bokare, A.; Sung, N.; Choi, W. Solar Production of $\mathrm{H}_{2} \mathrm{O}_{2}$ on Reduced Graphene Oxide- $\mathrm{TiO}_{2}$ Hybrid Photocatalysts Consisting of Earth-Abundant Elements Only. Energy Environ. Sci. 2014, 7, 4023-4028.

259. Tsukamoto, D.; Shiro, A.; Shiraishi, Y.; Sugano, Y.; Ichikawa, S.; Tanaka, S.; Hirai, T. Photocatalytic $\mathrm{H}_{2} \mathrm{O}_{2}$ Production from Ethanol/ $\mathrm{O}_{2}$ System Using $\mathrm{TiO}_{2}$ Loaded with Au-Ag Bimetallic Alloy Nanoparticles. ACS Catal. 2012, 2, 599-603.

260. Diesen, V.; Jonsson, M. Formation of $\mathrm{H}_{2} \mathrm{O}_{2}$ in $\mathrm{TiO}_{2}$ Photocatalysis of Oxygenated and Deoxygenated Aqueous Systems: A Probe for Photocatalytically Produced Hydroxyl Radicals. J. Phys. Chem. C 2014, 118, 10083-10087.

261. Lousada, C.M.; Johansson, A.J.; Brinck, T.; Jonsson, M. Mechanism of $\mathrm{H}_{2} \mathrm{O}_{2}$ Decomposition on Transition Metal Oxide Surfaces. J. Phys. Chem. C2012, 116, 9533-9543. 
262. Bokare, A.D.; Choi, W. Review of Iron-Free Fenton-like Systems for Activating $\mathrm{H}_{2} \mathrm{O}_{2}$ in Advanced Oxidation Processes. J. Hazard. Mater. 2014, 275, 121-135.

263. Koppenol, W.H. The Haber-Weiss Cycle-70 Years Later. Redox Rep. 2001, 6, 229-234.

264. Shiraishi, Y.; Kanazawa, S.; Sugano, Y.; Tsukamoto, D.; Sakamoto, H.; Ichikawa, S.; Hirai, T. Highly Selective Production of Hydrogen Peroxide on Graphitic Carbon Nitride $\left(\mathrm{g}_{-} \mathrm{C}_{3} \mathrm{~N}_{4}\right)$ Photocatalyst Activated by Visible Light. ACS Catal. 2014, 4, 774-780.

265. Zhang, J.; Chen, X.; Takanabe, K.; Maeda, K.; Domen, K.; Epping, J.D.; Fu, X.; Antonietti, M.; Wang, X. Synthesis of a Carbon Nitride Structure for Visible-Light Catalysis by Copolymerization. Angew. Chem. Int. Ed. 2010, 49, 441-444.

266. Abe, R.; Takami, H.; Murakami, N.; Ohtani, B. Pristine Simple Oxides as Visible Light Driven Photocatalysts: Highly Efficient Decomposition of Organic Compounds over Platinum-Loaded Tungsten Oxide. J. Am. Chem. Soc. 2008, 130, 7780-7781.

267. Rostrup-Nielsen, J.R. Steam Reforming and Chemical Recuperation. Catal. Today 2009, 145, 72-75.

268. Hodoshima, S.; Shono, A.; Saito, Y. Chemical Recuperation of Low-Quality Waste Heats by Catalytic Dehydrogenation of Organic Chemical Hydrides and Its Exergy Analysis. Energy Fuels 2008, 22, 2559-2569.

269. Poullikkas, A. An Overview of Current and Future Sustainable Gas Turbine Technologies. Renew. Sustain. Energy Rev. 2005, 9, 409-443.

270. Sun, J.; Wang, Y. Recent Advances in Catalytic Conversion of Ethanol to Chemicals. ACS Catal. 2014, 4, 1078-1090.

271. Makshina, E.V.; Dusselier, M.; Janssens, W.; Degrève, J.; Jacobs, P.A.; Sels, B.F. Review of Old Chemistry and New Catalytic Advances in the On-Purpose Synthesis of Butadiene. Chem. Soc. Rev. 2014, 43, 7917-7953.

272. Alcalá, R.; Mavrikakis, M.; Dumesic, J.A. DFT Studies for Cleavage of $\mathrm{C}-\mathrm{C}$ and $\mathrm{C}-\mathrm{O}$ Bonds in Surface Species Derived from Ethanol on Pt(111). J. Catal. 2003, 218, 178-190.

273. Ferrin, P.; Simonetti, D.; Kandoi, S.; Kunkes, E.; Dumesic, J.A.; Nørskov, J.K.; Mavrikakis, M. Modeling Ethanol Decomposition on Transition Metals: A Combined Application of Scaling and Brønsted-Evans-Polanyi Relations. J. Am. Chem. Soc. 2009, 131, 5809-5815.

274. Salemme, L.; Menna, L.; Simeone, M. Thermodynamic Analysis of Ethanol Processors_-PEM Fuel Cell Systems. Int. J. Hydrog. Energy 2010, 35, 3480-3489.

275. Ni, M.; Leung, D.Y.C.; Leung, M.K.H. A Review on Reforming Bio-Ethanol for Hydrogen Production. Int. J. Hydrog. Energy 2007, 32, 3238-3247.

276. Xu, W.Q.; Liu, Z.Y.; Johnston-Peck, A.C.; Senanayake, S.D.; Zhou, G.; Stacchiloa, D.; Stach, E.A.; Rodriguez, J.A. Steam Reforming of Ethanol on $\mathrm{Ni} / \mathrm{CeO}_{2}$ : Reaction Pathway and Interaction between $\mathrm{Ni}$ and the $\mathrm{CeO}_{2}$ Support. ACS Catal. 2013, 3, 975-984.

277. Sanchez-Sanchez, M.C.; Yerga, R.M.N.; Kondarides, D.I.; Verykios, X.E.; Fierro, J.L.G. Mechanistic Aspects of the Ethanol Steam Reforming Reaction for Hydrogen Production on Pt, $\mathrm{Ni}$, and Pt/Ni Catalysts Supported on $\gamma-\mathrm{Al}_{2} \mathrm{O}_{3}$. J. Phys. Chem. A 2010, 114, 3873-3882.

278. Highfield, J.; Geiger, F.; Uenala, E.; Schucan, T. Hydrogen Release by Steam-Reforming of Ethanol for Efficient \& Clean Fuel Applications. In Proceedings of the 10th World Hydrogen Energy Conference, Cocoa Beach, FL, USA, 20-24 June 1994; Hydrogen Energy Progress X; Block, D.L., Veziroglu, T.N., Eds.; Volume 2, p. 1039. 
279. Sutton, J.E.; Panagiotopoulou, P.; Verykios, X.E.; Vlachos, D.G. Combined DFT, Microkinetic, and Experimental Study of Ethanol Steam Reforming on Pt. J. Phys. Chem. C 2013, 117, 4691-4706.

280. Maihom, T.; Probst, M.; Limtrakul, J. Density Functional Theory Study of the Dehydrogenation of Ethanol to Acetaldehyde over the Au-Exchanged ZSM-5 Zeolite: Effect of Surface Oxygen. J. Phys. Chem. C 2014, 118, 18564-18572.

281. Morgenstern, D.A.; Fornango, J.P. Low-Temperature Reforming of Ethanol over Copper-Plated Raney Nickel: A New Route to Sustainable Hydrogen for Transportation. Energy Fuels 2005, 19, 1708-1716.

282. Bowker, M.; Holroyd, R.; Perkins, N.; Bhantoo, J.; Counsell, J.; Carley, A.; Morgan, C. Acetaldehyde Adsorption and Catalytic Decomposition on Pd (110) and the Dissolution of Carbon. Surf. Sci. 2007, 601, 3651-3660.

283. Pichat, P.; Mozzanega, M.N.; Disdier, J.; Herrmann, J.M. Pt Content and Temperature Effects on the Photocatalytic $\mathrm{H}_{2}$ production from Aliphatic Alcohols over $\mathrm{Pt} / \mathrm{TiO}_{2}$. New J. Chem. (Nouv. J. Chim.) 1982, 6, 559-564.

284. Pichat, P.; Hermann, J.M.; Disdier, J.; Courbon, H.; Mozzanega, M.N. Photocatalytic Hydrogen Production from Aliphatic Alcohols over a Bifunctional Platinum on Titanium Dioxide Catalyst. New J. Chem. (Nouv. J. Chim.) 1981, 5, 627-636.

285. Millard, L.; Bowker, M. Photocatalytic Water-Gas Shift Reaction at Ambient Temperature. J. Photochem. Photobiol. A Chem. 2002, 148, 91-95.

286. Bowker, M.; James, D.; Stone, P.; Bennett, R.; Perkins, N.; Millard, L.; Greaves, J.; Dickinson, A. Catalysis at the Metal-Support Interface: Exemplified by the Photocatalytic Reforming of Methanol on $\mathrm{Pd} / \mathrm{TiO}_{2}$. J. Catal. 2004, 217, 427-433.

287. Al-Mazroai, L.S.; Bowker, M.; Davies, P.; Dickinson, A.; Greaves, J.; James, D.; Millard, L. The Photocatalytic Reforming of Methanol. Catal. Today 2007, 122, 46-50.

288. Highfield, J.G.; Chen, M.H.; Nguyen, P.T.; Chen, Z. Mechanistic Investigations of Photo-Driven Processes over $\mathrm{TiO}_{2}$ by in-situ DRIFTS-MS: Part 1: Platinization and Methanol Reforming. Energy Environ. Sci. 2009, 2, 991-1002.

289. Daskalaki, V.M.; Kondarides, D.I. Efficient Production of Hydrogen by Photo-Induced Reforming of Glycerol at Ambient Conditions. Catal. Today 2009, 144, 75-80.

290. Taboada, E.; Angurell, I.; Llorca, J. Dynamic Photocatalytic Hydrogen Production from Ethanol-Water Mixtures in an Optical Fiber Honeycomb Reactor Loaded with $\mathrm{Au} / \mathrm{TiO}_{2}$. J. Catal. 2014, 309, 460-467.

291. Puga, A.V.; Forneli, A.; García, H.; Corma, A. Production of $\mathrm{H}_{2}$ by Ethanol Photoreforming on $\mathrm{Au} / \mathrm{TiO}_{2}$. Adv. Funct. Mater. 2014, 24, 241-248.

292. Murdoch, M.; Waterhouse, G.I.N.; Nadeem, M.A.; Metson, J.B.; Keane, M.A.; Howe, R.F.; Llorca, J.; Idriss, H. The Effect of Gold Loading and Particle Size on the Photocatalytic Hydrogen Production from Ethanol on $\mathrm{Au} / \mathrm{TiO}_{2}$ Nanoparticles. Nat. Chem. 2011, 3, 489-492.

293. Gallo, A.; Marelli, M.; Psaro, R.; Gombac, V.; Montini, T.; Fornasiero, P.; Pievo, R.; Dal Santo, V. Bimetallic $\mathrm{Au}-\mathrm{Pt} / \mathrm{TiO}_{2}$ Photocatalysts Active under UV-A and Simulated Sunlight for $\mathrm{H}_{2}$ Production from Ethanol. Green Chem. 2012, 14, 330-333. 
294. Strataki, N.; Bekiari, V.; Kondarides, D.I.; Lianos, P. Hydrogen production by photocatalytic alcohol reforming employing highly efficient Nanocrystalline Titania films. Appl. Catal. B Environ. 2007, 77, 184-189.

295. Languer, M.P.; Scheffer, F.R.; Feil, A.F.; Baptista, D.L.; Migowski, P.; Macahdo, G.J.; de Moraes, D.P.; Dupont, J.; Teixeira, S.R.; Weibel, D.E. Photo-Induced Reforming of Alcohols with Improved Hydrogen Apparent Quantum Yield on $\mathrm{TiO}_{2}$ Nanotubes Loaded with Ultra-Small Pt Nanoparticles. Int. J. Hydrog. Energy 2013, 38, 14440-14450.

296. Bowker, M.; Morton, C.; Kennedy, J.; Bahruji, H.; Greves, J.; Jones, W.; Davies, P.R.; Brookes, C.; Wells, P.P.; Dimitratos, N. Hydrogen Production by Photoreforming of Biofuels using Au, Pd and Au-Pd/TiO 2 Photocatalysts. J. Catal. 2014, 310, 10-15.

297. Taboada, E.; Angurell, I.; Llorca, J. Hydrogen Photoproduction from Bio-derived Alcohols in an Optical Fiber Honeycomb Reactor Loaded with $\mathrm{Au} / \mathrm{TiO}_{2}$. J. Photochem. Photobiol. A Chem. 2014, 281, 35-39.

298. Bowker, M. Sustainable Hydrogen Production by the Application of Ambient Temperature Photocatalysis. Green Chem. 2011, 13, 2235-2246.

299. Bowker, M.; Davies, P.R.; al-Mazroai, L.S. Photocatalytic Reforming of Glycerol over Gold and Palladium as an Alternative Fuel Source. Catal. Lett. 2009, 128, 253-255.

300. Luo, N.; Jiang, Z.; Shi, H.; Cao, F.; Xiao, T.; Edwards, P.P. Photo-Catalytic Conversion of Oxygenated Hydrocarbons to Hydrogen over Heteroatom-Doped $\mathrm{TiO}_{2}$ Catalysts. Int. J. Hydrog. Energy 2009, $34,125-129$.

301. Fu, X.; Long, J.; Wang, X.; Leung, D.Y.C.; Ding, Z.; Wu, L.; Zhang, Z.; Li, Z.; Fu, X. Photocatalytic Reforming of Biomass: A Systematic Study of Hydrogen Evolution from Glucose Solution. Int. J. Hydrog. Energy 2008, 33, 6484-6491.

302. Zheng, X.J.; Wei, L.F.; Zhang, Z.H.; Jiang, Q.J.; Wei, Y.J.; Xie, B.; Wei, M.B. Research on Photocatalytic $\mathrm{H}_{2}$ Production from Acetic Acid Solution by $\mathrm{Pt} / \mathrm{TiO}_{2}$ Nanoparticles under UV Irradiation. Int. J. Hydrog. Energy 2009, 34, 9033-9041.

303. Kraeutler, B.; Bard, A.J. Heterogeneous Photocatalytic Synthesis of Methane from Acetic Acid-New Kolbe Reaction Pathway. J. Am. Chem. Soc. 1978, 100, 2239-2240.

304. Tanaka, A.; Sakaguchi, S.; Hashimoto, K.; Kominami, H. Preparation of $\mathrm{Au} / \mathrm{TiO}_{2}$ with Metal Cocatalysts Exhibiting Strong Surface Plasmon Resonance Effective for Photoinduced Hydrogen Formation under Irradiation of Visible Light. ACS Catal. 2013, 3, 79-85.

305. Lyubina, T.P.; Markovskaya, D.V.; Kozlova, E.A.; Parmon, V.N. Photocatalytic Hydrogen Evolution from Aqueous Solutions of Glycerol under Visible Light Irradiation. Int. J. Hydrog. Energy 2013, 38, 14172-14179.

306. Melo, M.D.; Silva, L.A. Visible-Light-Induced Hydrogen Production from Glycerol Aqueous Solution on Hybrid Pt-CdS-TiO2 Photocatalysts. J. Photochem. Photobiol. A Chem. 2011, 226, 36-41.

307. Carraro, G.; Gasparotto, A.; Maccato, C.; Gombac, V.; Rossi, F.; Montini, T.; Peeters, D.; Bontempi, E.; Sada, C.; Barreca, D.; et al. Solar $\mathrm{H}_{2}$ Generation via Ethanol Photoreforming on $\varepsilon-\mathrm{Fe}_{2} \mathrm{O}_{3}$ Nanorod Arrays Activated by Ag and Au Nanoparticles. RSC Adv. 2014, 4, 32174-32179. 
308. Carraro, G.; Maccato, C.; Gasparotto, A.; Montini, T.; Turner, S.; Lebedev, O.I.; Gombac, V.; Adami, G.; van Tendeloo, G.; Barreca, D.; et al. Enhanced Hydrogen Production by Photoreforming of Renewable Oxygenates through Nanostructured $\mathrm{Fe}_{2} \mathrm{O}_{3}$ Polymorphs. Adv. Funct. Mater. 2014, 24, 372-378.

309. Kim, G.; Lee, S.H.; Choi, W. Glucose-TiO 2 Charge Transfer Complex-Mediated Photocatalysis under Visible Light. Appl. Catal. B Environ. 2015, 162, 463-469.

310. Clarizia, L.; Spasiano, D.; di Somma, I.; Marotta, R.; Andreozzi, R.; Dionysiou, D.D. Copper Modified- $\mathrm{TiO}_{2}$ Catalysts for Hydrogen Generation through Photoreforming of Organics. A Short Review. Int. J. Hydrog. Energy 2014, 39, 16812-16831.

311. Ampelli, C.; Passalacqua, R.; Genovese, C.; Perathoner, S.; Centi, G.; Montini, T.; Gombac, V.; Jaen, J.J.D.; Fornasiero, P. $\mathrm{H}_{2}$ Production by Selective Photo-Dehydrogenation of Ethanol in Gas and Liquid Phase on $\mathrm{CuO}_{\mathrm{x}} / \mathrm{TiO}_{2}$ Nanocomposites. RSC Adv. 2013, 3, 21776-21788.

312. Liu, R.X.; Yoshida, H.; Fujita, S.; Arai, M. Photocatalytic Hydrogen Production from Glycerol and Water with $\mathrm{NiO}_{x} / \mathrm{TiO}_{2}$ Catalysts. Appl. Catal. B Environ. 2014, 144, 41-45.

313. Shkrob, I.A.; Dimitrijevic, N.M.; Marin, T.W.; He, H.; Zapol, P. Heteroatom-Transfer Coupled Photoreduction and Carbon Dioxide Fixation on Metal Oxides. J. Phys. Chem. C 2012, 116, 9461-9471.

314. Shkrob, I.A.; Marin, T.W.; He, H.; Zapol, P. Photoredox Reactions and the Catalytic Cycle for Carbon Dioxide Fixation and Methanogenesis on Metal Oxides. J. Phys. Chem. C 2012, 116, 9450-9460.

315. Mori, K.; Yamashita, H.; Anpo, M. Photocatalytic Reduction of $\mathrm{CO}_{2}$ with $\mathrm{H}_{2} \mathrm{O}$ on Various Titanium Oxide Photocatalysts. RSC Adv. 2012, 2, 3165-3172.

316. He, H.; Zapol, P.; Curtiss, L.A. Computational Screening of Dopants for Photocatalytic Two-Electron Reduction of $\mathrm{CO}_{2}$ on Anatase (101) Surfaces. Energy Environ. Sci. 2012, 5, 6196-6205.

317. Tu, W.; Zhou, Y.; Zou, Z. Photocatalytic Conversion of $\mathrm{CO}_{2}$ into Renewable Hydrocarbon Fuels: State-of-the-Art Accomplishment, Challenges, and Prospects. Adv. Mater. 2014, 26, 4607-4626.

318. Peterson, A.A.; Abild-Pedersen, F.; Studt, F.; Rossmeisl, J.; Nørskov, J.K. How Copper Catalyzes the Electroreduction of Carbon Dioxide into Hydrocarbon Fuels. Energy Environ. Sci. 2010, 3, 1311-1315.

319. Behrens, M.; Studt, F.; Kasatkin, I.; Kühl, S.; Hävecker, M.; Abild-Pedersen, F.; Zander, S.; Girgsdies, F.; Kurr, P.; Kniep, B.L.; et al. The Active Site of Methanol Synthesis over Cu/ZnO/Al $\mathrm{O}_{3}$ Industrial Catalysts. Science 2012, 336, 893-897.

320. Ola, O.; Maroto-Valer, M.M. Copper-based $\mathrm{TiO}_{2}$ Honeycomb Monoliths for $\mathrm{CO}_{2}$ Photoreduction. Catal. Sci. Technol. 2014, 4, 1631-1637.

321. Nunez, J.; O’Shea, V.A.D.; Jana, P.; Coronado, J.M.; Serrano, D.P. Effect of Copper on the Performance of $\mathrm{ZnO}$ and $\mathrm{ZnO}_{1-\mathrm{x}} \mathrm{N}_{\mathrm{x}}$ Oxides as $\mathrm{CO}_{2}$ Photoreduction Catalysts. Catal. Today 2013, 209, 21-27.

322. Mao, J.; Li, K.; Peng, T.Y. Recent Advances in the Photocatalytic $\mathrm{CO}_{2}$ Reduction over Semiconductors. Catal. Sci. Technol. 2013, 3, 2481-2498.

323. Richardson, P.L.; Perdigoto, M.L.N.; Wang, W.; Lopes, R.J.G. Manganese- and Copper-Doped Titania Nanocomposites for the Photocatalytic Reduction of Carbon Dioxide into Methanol. Appl. Catal. B Environ. 2012, 126, 200-207. 
324. Kuhl, K.P.; Hatsukade, T.; Cave, E.R.; Abram, D.N.; Kibsgaard, J.; Jaramillo, T.F. Electrocatalytic Conversion of Carbon Dioxide to Methane and Methanol on Transition Metal Surfaces. J. Am. Chem. Soc. 2014, 136, 14107-14113.

325. Constentin, C.; Robert, M.; Saveant, J.M. Catalysis of the Electrochemical Reduction of Carbon Dioxide. Chem. Soc. Rev. 2013, 42, 2423-2436.

326. Kuhl, K.P.; Cave, E.R.; Abram, D.N.; Jaramillo, T.F. New Insights into the Electrochemical Reduction of Carbon Dioxide on Metallic Copper Surfaces. Energy Environ. Sci. 2012, 5, 7050-7059.

327. Tu, W.; Zhou, Y.; Zou, Z. Versatile Graphene-Promoting Photocatalytic Performance of Semiconductors: Basic Principles, Synthesis, Solar Energy Conversion, and Environmental Applications. Adv. Funct. Mater. 2013, 23, 4996-5008.

328. Fan, W.; Zhang, Q.; Wang, Y. Semiconductor-Based Nanocomposites for Photocatalytic $\mathrm{H}_{2}$ Production and $\mathrm{CO}_{2}$ Conversion. Phys. Chem. Chem. Phys. 2013, 15, 2632-2649.

329. Leary, R.; Westwood, A. Carbonaceous Nanomaterials for the Enhancement of $\mathrm{TiO}_{2}$ Photocatalysis. Carbon 2011, 49, 741-772.

330. Liang, Y.T.; Vijayan, B.K.; Gray, K.A.; Hersam, M.C. Minimizing Graphene Defects Enhances Titania Nanocomposite-Based Photocatalytic Reduction of $\mathrm{CO}_{2}$ for Improved Solar Fuel Production. Nano Lett. 2011, 11, 2865-2870.

331. Tu, W.G.; Zhou, Y.; Liu, Q.; Tian, Z.P.; Gao, J.; Chen, X.Y.; Zhang, H.T.; Liu, J.G.; Zou, Z.G. Robust Hollow Spheres Consisting of Alternating Titania Nanosheets and Graphene Nanosheets with High Photocatalytic Activity for $\mathrm{CO}_{2}$ Conversion into Renewable Fuels. Adv. Funct. Mater. 2012, 22, 1215-1221.

332. Xia, X.H.; Jia, Z.H.; Yu, Y.; Liang, Y.; Wang, Z.; Ma, L.L. Preparation of Multi-Walled Carbon Nanotube Supported $\mathrm{TiO}_{2}$ and Its Photocatalytic Activity in the Reduction of $\mathrm{CO}_{2}$ with $\mathrm{H}_{2} \mathrm{O}$. Carbon 2007, 45, 717-721.

333. Centi, G.; Perathoner, S. Opportunities and Prospects in the Chemical Recycling of Carbon Dioxide to Fuels. Catal. Today 2009, 148, 191-205.

334. Yao, Y.; Li, G.; Ciston, S.; Lueptow, R.M.; Gray, K.A. Photoreactive $\mathrm{TiO}_{2} /$ Carbon Nanotube Composites: Synthesis and Reactivity. Environ. Sci. Technol. 2008, 42, 4952-4957.

335. Hsu, H.C.; Shown, I.; Wei, H.Y.; Chang, Y.C.; Du, H.Y.; Lin, Y.G.; Tseng, C.A.; Wang, C.H.; Chen, L.C.; Lin, Y.C.; et al. Graphene Oxide as a Promising Photocatalyst for $\mathrm{CO}_{2}$ to Methanol Conversion. Nanoscale 2013, 5, 262-268.

336. Shown, I.; Hsu, H.C.; Chang, Y.C.; Lin, C.H.; Roy, P.K.; Ganguly, A.; Wang, C.H.; Chang, J.K.; Wu, C.I.; Chen, L.C.; et al. Highly Efficient Visible Light Photocatalytic Reduction of $\mathrm{CO}_{2}$ to Hydrocarbon Fuels by Cu-Nanoparticle Decorated Graphene Oxide. Nano Lett. 2014, 14, 6097-6103.

337. Kumar, P.; Kumar, A.; Sreedhar, B.; Sain, B.; Ray, S.S.; Jain, S.L. Cobalt Phthalocyanine Immobilized on Graphene Oxide: An Efficient Visible-Active Catalyst for the Photoreduction of Carbon Dioxide. Chem. Eur. J. 2014, 20, 6154-6161.

338. Li, X.; Liu, H.; Luo, D.; Li, J.; Huang, Y.; Li, H.; Fang, Y.; Xu, Y.; Zhu, L. Adsorption of $\mathrm{CO}_{2}$ on Heterostructure $\mathrm{CdS}\left(\mathrm{Bi}_{2} \mathrm{~S}_{3}\right) / \mathrm{TiO}_{2}$ Nanotube Photocatalysts and Their Photocatalytic Activities in the Reduction of $\mathrm{CO}_{2}$ to Methanol under Visible Light Irradiation. Chem. Eng. J. 2012, 180, 151-158.

339. Wang, C.; Thompson, R.L.; Baltrus, J. Matranga, Visible Light Photoreduction of $\mathrm{CO}_{2}$ Using $\mathrm{CdSe} / \mathrm{Pt} / \mathrm{TiO}_{2}$ Heterostructured Catalysts. J. Phys. Chem. Lett. 2010, 1, 48-53. 
340. Hou, W.B.; Hung, W.H.; Pavaskar, P.; Goeppert, A.; Aykol, M.; Cronin, S.B. Photocatalytic Conversion of $\mathrm{CO}_{2}$ to Hydrocarbon Fuels via Plasmon-Enhanced Absorption and Metallic Interband Transitions. ACS Catal. 2011, 1, 929-936.

341. Centi, G.; Perathoner, S. Catalysis: Role and Challenges for a Sustainable Energy. Top. Catal. 2009, 52, 948-961.

342. Gangeri, M.; Perathoner, S.; Caudo, S.; Centi, G.; Amadou, J.; Bégon, D.; Pham-Huu, C.; Ledoux, M.J.; Tessonier, J.P.; Su, D.S.; et al. Fe and Pt Carbon Nanotubes for the Electrocatalytic Conversion of Carbon Dioxide to Oxygenates. Catal. Today 2009, 143, 57-63.

343. Grabow, L.C.; Mavrikakis, M. Mechanism of Methanol Synthesis on $\mathrm{Cu}$ through $\mathrm{CO}_{2}$ and $\mathrm{CO}$ Hydrogenation. ACS Catal. 2011, 1, 365-384.

344. Cheng, D.; Negreiros, F.R.; Aprà, E.; Fortunelli. A. Computational Approaches to the Chemical Conversion of Carbon Dioxide. ChemSusChem 2013, 6, 944-965.

345. Lazo, N.D.; Murray, D.K.; Kieke, M.L.; Haw, J.F. In-Situ C-13 Solid-State NMR Study of the $\mathrm{Cu} / \mathrm{ZnO} / \mathrm{Al}_{2} \mathrm{O}_{3}$ Methanol Synthesis Catalyst. J. Am. Chem. Soc. 1992, 114, 8552-8559.

346. Idriss, H.; Kim, K.S.; Barteau, M.A. Surface-Dependent Pathways for Formaldehyde Oxidation and Reduction on $\mathrm{TiO}_{2}(001)$. Surf. Sci. 1992, 262, 113-127.

347. Busca, G.; Lamotte, J.; Lavalley, J.C.; Lorenzelli, V. FTIR Study of the Adsorption and Transformation of Formaldehyde on Oxide Surfaces. J. Am. Chem. Soc. 1987, 109, 5197-5202.

348. Rzepa, H.S.; Miller, J. An MNDO SCF-MO Study of the Mechanism of the Cannizzaro Reaction. J. Chem. Soc. Perkin Trans. II 1985, 717-723, doi:10.1039/P29850000717.

349. Harriman, A. Prospects for Conversion of Solar Energy into Chemical Fuels: The Concept of a Solar Fuels Industry. Philos. Trans. R. Soc. A 2013, 371, 20110415.

350. Thomas, J.M. Reflections on the Topic of Solar Fuels. Energy Environ. Sci. 2014, 7, 19-20.

351. Malato, S.; Fernández-Ibáñez, P.; Maldonado, M.I.; Oller, I.; Polo-López, M.I. Solar Photocatalytic Pilot Plants: Commercially Available Reactors. In Photocatalysis and Water Purification: From Fundamentals to Recent Applications; Pichat, P., Ed.; Wiley-VCH Verlag: Weinheim, Germany, 2013; Chapter 15.

352. Villa, K.; Domènech, X.; Malato, S.; Maldonado, M.I.; Peral, J. Heterogeneous Photocatalytic Hydrogen Generation in a Solar Pilot Plant. Int. J. Hydrog. Energy 2013, 38, 12718-12724.

353. James, B.D.; Baum, G.N.; Perez, J.; Baum, K.N. Technoeconomic Analysis of Photoelectrochemical (PEC) Hydrogen Production; Directed Technologies Inc.: Arlington, VA, USA, 2009; US DOE Contract no. GS-10F-009.

354. Döscher, H.; Geisz, J.F.; Deutsch, T.G.; Turner, J.A. Sunlight Absorption in Water-Efficiency and Design Implications for Photoelectrochemical Devices. Energy Environ. Sci. 2014, 7, 2951-2956.

355. Seitz, L.C.; Chen, Z.; Forman, A.J.; Pinaud, B.A.; Benck, J.D.; Jaramillo, T.F. Modeling Practical Performance Limits of Photoelectrochemical Water Splitting Based on the Current State of Materials Research. ChemSusChem 2014, 7, 1372-1385.

356. Haussener, S.; Xiang, C.; Spurgeon, J.M.; Ardo, S.; Lewis, N.S.; Weber, A.Z. Modeling, Simulation, and Design Criteria for Photoelectrochemical Water-Splitting Systems. Energy Environ. Sci. 2012, 5, 9922-9935.

357. Rodriguez, C.A.; Modestino, M.A.; Psaltis, D.; Moser, C. Design and Cost Considerations for Practical Solar-Hydrogen Generators. Energy Environ. Sci. 2014, 7, 3828-3835. 
358. Chandross, E.A. Shining a Light on Solar Water Splitting. Science 2014, 344, 469.

359. Turner, J.A. Response to Chandross. Science 2014, 344, 469-470.

360. Chen, Y.; Xiang, C.; Hu, C.; Lewis, N.S. Modeling the Performance of an Integrated Photoelectrolysis System with 10× Solar Concentrators. J. Electrochem. Soc. 2014, 161, F1101-F1110.

361. Khamooshi, M.; Salati, H.; Egelioglu, F.; Faghiri, A.H.; Tarabishi, J.; Babadi, S. A Review of Solar Photovoltaic Concentrators. Int. J. Photoenergy 2014, doi:10.1155/2014/958521.

362. Swanson, R.M. The Promise of Concentrators. Prog. Photovolt. Res. Appl. 2000, 8, 93-111.

363. Hoffmann, M.R.; Martin, S.T.; Choi, W.; Bahnemann, D.W. Environmental Applications of Semiconductor Photocatalysis. Chem. Rev. 1995, 95, 69-96.

364. Khaselev, O.; Turner, J.A. A Monolithic Photovoltaic-Photoelectrochemical Device for Hydrogen Production via Water Splitting. Science 1998, 280, 425-427.

365. Joo, O.S.; Jung, K.D.; Jung, Y.S. CAMERE Process for Methanol Synthesis from $\mathrm{CO}_{2}$ Hydrogenation. In Carbon Dioxide Utilization for Global Sustainability; Park, S.E., Chang, J.S., Lee, K.W., Eds.; Elsevier: Amsterdam, The Netherlands, 2004; Volume 153, pp. 67-72.

366. Ikeue, K.; Nozaki, S.; Ogawa, M.; Anpo, M. Photocatalytic Reduction of $\mathrm{CO}_{2}$ with $\mathrm{H}_{2} \mathrm{O}$ on Ti-Containing Porous Silica Thin-Film Photocatalysts. Catal. Lett. 2002, 80, 111-114.

367. Lackner, K.S. A Guide to $\mathrm{CO}_{2}$ Sequestration. Science 2003, 300, 1677-1678.

368. Gerdemann, S.J.; O’Connor, W.K.; Dahlin, D.C.; Penner, L.R.; Rush, H. Ex Situ Aqueous Mineral Carbonation. Environ. Sci. Technol. 2007, 41, 2587-2593.

369. Khoo, H.H.; Sharratt, P.N.; Bu, J.; Yeo, T.Y.; Borgna, A.; Highfield, J.G.; Björklöf, T.G.; Zevenhoven, R. Carbon Capture and Mineralization in Singapore: Preliminary Environmental Impacts and Costs via LCA. Ind. Eng. Chem. Res. 2011, 50, 11350-11357.

370. Zevenhoven, R.; Fagerlund, J.; Nduagu, E.; Romão, I.; Bu, J.; Highfield, J. Carbon Storage by Mineralisation (CSM): Serpentinite Rock Carbonation via $\mathrm{Mg}(\mathrm{OH})_{2}$ Reaction Intermediate without $\mathrm{CO}_{2}$ Pre-Separation [GHGT-11]. Energy Proced. 2013, 37, 5945-5954.

371. Sanna, A.; Uibu, M.; Caramanna, G.; Kuusik, R.; Maroto-Valer, M.M. A Review of Mineral Carbonation Technologies to Sequester $\mathrm{CO}_{2}$. Chem. Soc. Rev. 2014, 43, 8049-8080.

(C) 2015 by the authors; licensee MDPI, Basel, Switzerland. This article is an open access article distributed under the terms and conditions of the Creative Commons Attribution license (http://creativecommons.org/licenses/by/4.0/). 